\title{
Brain natriuretic peptide
}

Citation for published version (APA):

van Zander, K. (2003). Brain natriuretic peptide. [Doctoral Thesis, Maastricht University]. Datawyse / Universitaire Pers Maastricht. https://doi.org/10.26481/dis.20030425kz

Document status and date:

Published: 01/01/2003

DOI:

$10.26481 /$ dis.20030425kz

Document Version:

Publisher's PDF, also known as Version of record

\section{Please check the document version of this publication:}

- A submitted manuscript is the version of the article upon submission and before peer-review. There can be important differences between the submitted version and the official published version of record.

People interested in the research are advised to contact the author for the final version of the publication, or visit the DOI to the publisher's website.

- The final author version and the galley proof are versions of the publication after peer review.

- The final published version features the final layout of the paper including the volume, issue and page numbers.

Link to publication

\footnotetext{
General rights rights.

- You may freely distribute the URL identifying the publication in the public portal. please follow below link for the End User Agreement:

www.umlib.nl/taverne-license

Take down policy

If you believe that this document breaches copyright please contact us at:

repository@maastrichtuniversity.nl

providing details and we will investigate your claim.
}

Copyright and moral rights for the publications made accessible in the public portal are retained by the authors and/or other copyright owners and it is a condition of accessing publications that users recognise and abide by the legal requirements associated with these

- Users may download and print one copy of any publication from the public portal for the purpose of private study or research.

- You may not further distribute the material or use it for any profit-making activity or commercial gain

If the publication is distributed under the terms of Article $25 \mathrm{fa}$ of the Dutch Copyright Act, indicated by the "Taverne" license above, 


\section{Brain Natriuretic Peptide}


(c) Kim van der Zander, Maastricht 2003

ISBN $905278373 X$

Produetion: Datawyse | Universitaire Pers Maastricht

Cover design: Jeroen de Bruin

Lay-out: Tiny Wouters

Financial support by the Netherlands Heart Foundation for the publication of this thesis is gratefully acknowledged. 


\title{
Brain Natriuretic Peptide
}

\author{
PROEFSCHRIFT
}

ter verkriiging van de graad van doctor aan de Universiteit Maastricht.

op gezag van de Rector Magnificus,

Prof.dr. A.C. Nieuwenhuijzen Kruseman

volgens het besluit van het College van Decanen,

in het openbaar te verdedigen

op vrijdag 25 april 2003 om 12.00 uur

door

Kim van der Zander

Geboren op 30 september 1976 te Sittard

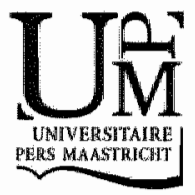




\section{Promotor}

Prof. dr. P.W. de Leeuw

\section{Co-promotor}

Dr. A.J.H.M. Houben

\section{Beoordelingscommissie}

Prof. dr. H.A.J. Struijker Boudier (voorzitter)

Prof. dr. H.J. Crijns

Prof. dr. M.P. van Dieijen-Visser

Prof. dr. E.B. Pedersen (Aarhus University, Denmark)

Prof. dr. D.J. Webb (University of Edinburgh, Scotland) 
Een hart dat pompt

De hartstocht

Waarmee iii

De dagen vult

Jouw bezigheid

Als bloed

Dat door mijn aderen stroomt

(Daniela Depau, 2003) 



\section{Contents}

Chapter 1 General introduction

Chapter 2 Hemodynamic and renal effects of low-dose Brain Natriuretic Peptide infusion in man

Chapter 3 Does Brain Natriuretic Peptide have a direct renal effect in human hypertensives?

Chapter 4 Selective endothelin-1 B receptor blockade inhibits basal, but not BNP-induced natriuresis

Chapter 5 Effects of Brain Natriuretic Peptide on forearm vasculature: comparison with atrial natriuretic peptide

Chapter 6 Nitric Oxide and potassium channels are involved in Brain Natriuretic Peptide induced vasodilatation in man

Chapter 7 Review: "Brain Natriuretic Peptide in human physiology; compensating mechanism in vascular disease?"

Chapter 8 Summary

Chapter 9 Samenvatting

List of publications

Dankwoord 



\section{Chapter 1}

General introduction 
Chapter 


\section{General introduction}

The cardiovascular system is under the control of several hemodynamic and neurohumoral mechanisms. These regulatory mechanisms play a key role in modulating cardiac function, vascular tone, and structure. Although they are essential in vascular homeostasis, they become maladaptive in cardiavascular disease states such as hypertension and heart failure. Except for the autonomic nervous system and the reninangiotensin-aldosterone system, this concerns the natriuretic peptides. The family of natriuretic peptides consists of atrial natriuretic peptide (ANP), brain natriuretic peptide (BNP) of primarily cardiac origin, and ctype natriuretic peptide (CNP) of endothelliall origin. Most research has focused on ANP, which was the first natriuretic peptide to be identified. Recently, however, many efforts have been directed towards BNP. In humans this peptide acts as a marker for left ventricular hypertrophy and cardiac failure. However, the (patho) physiological significance of BNP in cardiovascular homeostasis in man is not yet clear. Even though BNP has been successfully applied in the treatment of congestive heart failure, it remains elusive by which mechanisms this compound affects the vascular system and renal function. This lack of knowledge formed the impetus for this thesis. The overall objective of this thesis consist of two questions:

1. What are the hemodynamic effects of BNP on different target organs in humans?

2. What are the underlying mechanisms of action of BNP?

The hemodynamic and renal effects of low-dose BNP infusion in normal man are described in chapter 2 , while chapter 3 illustrates the local renal effects of BNP in hypertensive patients. The study in chapter 4 discusses endothelin-1 as a possible mediator of the BNP-induced renal effects. In chapter 5 the local effects of BNP on forearm vasculature are compared to those of ANP. Mechanisms of action of BNP that are involved in the effects on the forearm vasculature are described in chapter 6 . Finally, chapter 7 gives an overview of (recent) knowledge about BNP in healthy subjects and patients with hypertension and/or heart failure and the results of this thesis are discussed in the light of current literature. Chapter 8 and 9 concisely summarize the contents of this thesis. 



\section{Chapter 2}

\section{Hemodynamic and renal effects of low-dose Brain Natriuretic Peptide infusion in man}

K van der Zander, A.JHM Houben, L Hofstra, AA Kroon, PW de Leeuw 


\section{Abstract}

The present study wos designed to investigate the effects of low-dose brain notriuretic peptide (BMP) infusion on central, renal hemadynamics and microvascular hemodynamics in healthy subjects. To this end, we infused BNP or placebo for 1 hour, on wo separate days, in 12 healthy subjects. Nailfold and conjunctival capillary density, finger skin microvascular blood flow (SBF), cardiac output, effective renal plasma flow (ERPF) and glomerular filtration rate (GFR) were studied before and after infusion. Bload pressure and heart rate (HR) were monitored as well. Compared to placebo, BNP significantly decrecsed stroke volume with a tendency to decrease cardiac output. BNP decreased MAP and increased HR increased in sitting, but not in supine position. Natruresis, diuresis, GFR, filtration fraction, and filtered load of sodium increased during BNP relative to placebo, while ERPF did not change. BNP did not affect the microvascular capillary density of conjunctiva and skin, SBF, total skin oxygen capacity and postocclusive recruitment. The present results suggest that BNP has predominantly central and renal hemodynamic effects, while it does not influence peripheral microcirculation, at least in skin and conjunctiva. 


\section{Introduction}

Despite many investigations, the hemodynamic effects of brain natriuretic peptide (BNP) remain elusive. Whereas cardiac output (CO) and heart rate (HR) increased during BNP infusion in one study', these variables did not change in two others. ${ }^{2,3}$ Although variations in the cardiovascular effects of BNP could be due to differences in BNP levels reached during the experiments, it is equally possible that changes in cardiac output depend upon alterations in preload and, hence, upon differential effects of BNP on arteriolar and venular tone. Unfortunately, in man no information is available with respect to the main side of action of BNP in the vasculature. Therefore, the aim of our study was to investigate the effects of BNP on both central and peripheral hemodynamics in normal subjects. To this end, we performed a double blind randomised placebocontrolled crossover study with measurements of blood pressure, heart rate, cardiac output, renal hemodynamics, and various microcirculatory elements of the conjunctiva and skin before and after infusion of either placebo or BNP. In addition, we evaluated whether intrarenal forces could explain the enhanced natriuresis occurring during BNP administration. Because the pathophysiological role of BNP becomes particularly evident in older patients we selected for this study only individuals above age 50 years.

\section{Materials and methods}

\section{Subjects}

Experiments were performed in 12 healthy volunteers. During the week prior to the measurements, all subjects adhered to a $175 \mathrm{mmol} \mathrm{Na}^{*}$. containing dief so as to minimize variations in results due to salt intake. Compliance with the diet was checked by measuring sodium and creatinine output in 24-hour urine collections obtained during the last 24 hours before the first experimental day. None of the subjects used any medication (including non-steroidal anti-inflammatory drugs) during the two weeks prior to the measurements. In addition, they had to refrain from smoking and drinking caffeine or alcohol containing beverages for at least 12 hours before the experiments, which started at 8:30 a.m. after an overnight fast. The Medical Ethics Committee of the Maastricht University Hospital approved the study, and all participants gave written informed consent. The investigations conformed to the principles outlined in the Declaration of Helsinki. ${ }^{4}$ 


\section{Experimental design}

All volunteers were studied on two separate occasions (at least two days apart), during which they received in random order (double blind) an i.w. infusion of either BNP or vehicle (glucose 5\%). Experiments were performed in a quiet, temperature-controlled room (mean temperature $24.2 \pm 0.3^{\circ} \mathrm{C}$ ). Precautions were taken to minimize external disturbances. Except during the microcirculatory measurements (which had to performed in sitting position), subjects remained supine throughout the experiments. A 20 -gauge catheter was inserted into the antecubital vein of both arms. One was connected to a 3-way tap for infusion of BNP (Clinalfa, Ethifarma Nederland BV, The Netherlands) and para-amino hippurate (PAH)/inulin (for measuring renal hemodynamics), while the other was used for blood sampling. To ensure adequate diuresis, subjects consumed $200 \mathrm{~mL}$ of water every hour until the last blood samples had been drawn. At $t=0 \mathrm{~min}$ the $\mathrm{PAH} /$ inulin infusion was started. Between $t=0$ and $t=60$ min baseline measurements of the conjunctiva and nailfald microcirculation, skin blood flow, and total skin oxygen capacity were obtained. At $t=60 \mathrm{~min}$ an echocardiogram was taken. At $t=120 \mathrm{~min}$ the intravenous infusion of either BNP (4 $\mathrm{pmol} / \mathrm{kg} / \mathrm{min}$ ) or placebo (glucose $5 \%$ ) was started. At $t=180 \mathrm{~min}$ (i.e. after one hour of BNP or placebo infusion), a second echocardiogram was performed, followed by a second set of microvascular measurements. Blood pressure and heart rate (HR) were measured before and after the microvascular measurements in sitting position, and at 10 -minute intervals during the infusion in supine position. Blood samples were drawn at $t=0, t=120$, and $t=180 \mathrm{~min}$ for $\mathrm{PAH}$ and inulin and $a t=120$ and $t=180 \mathrm{~min}$ for determination of CGMP and BNP. Urine samples for measurement of sodium and potassium were collected at $t=60, t=120$, and $t=180 \mathrm{~min}$ (immediately affer blood sampling).

\section{Measurements}

\section{Systemic hemodynamics}

Systolic blood pressure (SBP), diastolic blood pressure (DBP), mean arterial blood pressure (MAP) and HR were measured by a semiautomatic oscillometric device (Dinamap Vital Signs Monitor 1846 , Critikon). CO was measured by echocardiography and total peripheral resistance (TPR) was calculated as (MAP/CO) * 80 and expressed in dyne $\cdot \mathrm{s} / \mathrm{cm}^{\mathrm{s}}$.

\section{Microcirculatory measurements}

The microcirculation of the lateral part of the bulbar conjunctiva of the right eye was studied with a custom build horizontal microscope, as described before. ${ }^{5}$ For microvascular density measurements, recordings 
were made on videotape with a standard achromatic objective $2.5 \mathrm{x}$ (numeric aperture (N.A.): 0.10 ). Arterioles, capillaries and venules were classified in several videoframes, using image analysis software (OPTIMAS version 5.0, Breda, The Netherlands). As a measure of density the total length of each microvascular class per square millimetre of conjunctiva was determined and averaged.

Measurement of nailfold capillary density was also performed as described earlier. ${ }^{6}$ For the capillary density measurements, recordings were made a few millimetres proximal to the terminal row of capillaries. Baseline skin capillary density was defined as the amount of erythrocytefilled capillaries in one videoscreen $\left(1.6 \mathrm{~mm}^{2}\right.$ of skin). The recruitment of functionally available capillaries was defined as the increase in the number of erythrocyte-filled capillaries after $4 \mathrm{~min}$ of arterial occlusion (by cuff inflation of $200 \mathrm{mmHg}$ at the wrist).

Skin blood flow (SBF), which predominantly reflects thermoregulatory flow, was determined simultaneously with nailfold capillary density using laser-Doppler fluxmetry (Periflux PF3; Perimed, Järfälla, Sweden), with probe $\mathrm{PF} 308$, wide band $(12 \mathrm{kHz})$ mode, and time constant $0.2 \mathrm{~s}$. Total skin oxygen capacity, a measure of nutritive blood flow, was determined using transcutaneous oxygen tension measurements ( $\mathrm{TCP} 2$, Radiometer), with the probe heated to $44^{\circ} \mathrm{C}$. Probes were placed on the dorsum of the interphalanx of the finger and the hand between dig. IV and $V$, respectively, of the same hand as nailfold capillary density was measured in. Flux values are expressed as arbitrary perfusion units, calibrated against an external standard. Total skin oxygen capacity is defined in $\mathrm{mmHg}$. SBF and total skin oxygen capacity were measured before and during reactive hyperemia following $4 \mathrm{~min}$ of arterial occlusion (200 $\mathrm{mmHg}$ ).

\section{Renal function}

Renal hemodynamics, i.e., effective renal plasma flow (ERPF) and glomerular filtration rate (GFR), were measured as the clearance of PAH (MSD, West Point, PA, USA) and inulin (Inutest, Laevosan Gesellschaft, Linz, Austria), respectively, during continuous infusion of these substances. ${ }^{7}$ Both GFR and ERPF were corrected for body surface area and expressed as $\mathrm{mL} /\left(\mathrm{min} \cdot 1.73 \mathrm{~m}^{2}\right)$. Effective renal blood flow (ERBF) was calculated by the following formula: ERPF/(1-hematocrit). Filtration Fraction (FF) was calculated as GFR/ERPF. Renal vascular resistance (RVR) was calculated according to the formula: (MAP/ERBF) ${ }^{*} 80000$ and expressed in dyne' $\mathrm{s} / \mathrm{cm}^{5}$. Renal Fraction (RF) was calculated as (ERBF/CO) * $100 \%$.

Filfered Load ( $\mathrm{FL}_{\mathrm{Na}}$ ) of sodium is calculated as GFR *60* $\left[\mathrm{Na}^{+}\right]_{\text {plosma }}$ and expressed in mmol/hr. Fractional Tubular Reabsorption of sodium (FTR $\mathrm{Na}_{\mathrm{Na}}$ ) is calculated as ( $\left.\left(\mathrm{FL}_{\mathrm{Na}}-U_{\mathrm{Na}} \mathrm{V}\right) / \mathrm{FL}_{\mathrm{Na}}\right) * 100 \%$, where $U_{\mathrm{Nal}}$ and $V$ are the urinary sodium concentration and urinary volume respectively. 


\section{Assay methods}

PAH and inulin levels were measured by means of a spectrophotometer. BNP and CGMP levels were measured by means of a competitive proteinbinding RIA (Peninsula Laboratories Inc. RIK 9086 and IBL Hamburg RE 29071 , respectively). Prior to assay, plasma samples of BNP were acidified and extracted using a SEP-Pak C18 column (Waters-Millipore). In our hands, the intra- and interassay variability of all assays were $<10 \%$. All samples from the same individual were assayed in a single run.

\section{Statistics}

Data are presented as medians with interquartile ranges $(\mid Q R)$. The Wilcoxon paired sign test for paired analysis (both within one visit and between the BNP and placebo infusion) and Friedman's test for analysis of multiple related measurements of MAP and HR (within one visit) were used. $P$ values below 0.05 denote statistical significance. Based on previous experiments we calculated that this study is able to demonstrate in 12 experimental subjects a $10 \%$ difference in any of the test variables with a power of $85 \%$

\section{Results}

Baseline clinical characteristics of the study participants are summarised in Table 2.1.

Table 2.1 Characteristics of the twelve study participants (median and $[Q R$ ).

\begin{tabular}{lc}
\hline Characteristic & Value \\
\hline No. (male/female) & $12(10 / 2)$ \\
Age, year & $61(57-63)$ \\
$B M, ~ k g / m^{2}$ & $26.0(24.0-27.1)$ \\
SBP, mmHg & $124(120-128)$ \\
DBP, mmHtg & $82(81-83)$ \\
HR, beats/min & $61(60-68)$ \\
Urinary sodium excretion, mmol/24h & $151(141-206)$ \\
\hline
\end{tabular}

(Bload pressure is the mean of 3 measurements by sphygmamanometer)

BMI, Body Mass index; SBP, Systolic Blood Pressure; DBP, Diastalic Blood Pressure; HR, Heant rate.

\section{Plasma levels of BNP and CGMP}

At baseline, BNP plasma levels did not differ between visits (Table 2.2). BNP infusion significantly increased plasma levels of this peptide to 191 
$(172-367) \mathrm{pg} / \mathrm{mL}(\mathrm{p}<0.01)$, while placebo infusion had no effect on BNP levels (21 (11-68) pg/mL affer infusion).

In parallel with the increase in BNP, plasma levels of cGMP also significantly increased to $19.5(15.6-25.6) \mathrm{pmol} / \mathrm{mLL}(p<0.01)$ after BNP infusion, while placebo infusion did not change levels of CGMP 6.6 (5.7. 7.5) $\mathrm{pmol} / \mathrm{mL}$ after infusion). No differences between cGMP vallues at baseline were observed (Table 2.2).

Table 2.2 Baseline data of all variables (supine) before placebo or BNP infusion.

\begin{tabular}{|c|c|c|}
\hline & Placebo & BNP \\
\hline BNNP, $\mathrm{pg} / \mathrm{mL}$ & $23(12-34)$ & $15(11-41)$ \\
\hline cGMP, $\mathrm{pmol} / \mathrm{mL}$ & $6.0(5.1-8.0)$ & $6.1(4.5-7.7)$ \\
\hline MAP, $\mathrm{mmHg}$ & $97(87-100)$ & $97(91-101)$ \\
\hline $\mathrm{HR}$, beats/min & $54(50.59)$ & $58(55-59)$ \\
\hline $\mathrm{SW}, \mathrm{mL}$ & $88(80.97)$ & $84(63-92)$ \\
\hline$C O, L$ & $4.9(4.1-6.3)$ & $4.8(4.1-6.0)$ \\
\hline $\mathrm{TPR}_{r}$ dyne $\cdot \mathrm{s} / \mathrm{cm}^{\mathrm{s}}$ & $1619(1258-1930)$ & $1580(1272.1933)$ \\
\hline ERPF, $\mathrm{mL} /\left(\mathrm{min} \cdot 1.73 \mathrm{~m}^{2}\right)$ & $386(315-488)$ & $413(334.439)$ \\
\hline ERBF, $\mathrm{mL} /\left(\mathrm{min} \cdot 1.73 \mathrm{~m}^{2}\right)$ & $612(546-871)$ & $745(566-759)$ \\
\hline GFR, $\mathrm{mL} /\left(\mathrm{min} \cdot 1.73 \mathrm{~m}^{2}\right)$ & $99(91-115)$ & $104(90-115)^{\circ}$ \\
\hline $\mathrm{FF}, \%$ & $26^{\prime}(24 \cdot 30)$ & $26(23-29)$ \\
\hline RVR, dyne $\mathrm{s} / \mathrm{cm}^{3}$ & $10622(8164-12371)$ & $9409(7182-13309)$ \\
\hline $\mathrm{RF}_{,} \%$ & $16(10-18)$ & $17(11-20)$ \\
\hline $\mathrm{U}_{\mathrm{No}} \mathrm{V}, \mathrm{mmol} / \mathrm{hr}$ & $9.0(7.3-11.8)$ & $6.0(5.7-9.6) *$ \\
\hline $\mathrm{V}, \mathrm{mL} / \mathrm{hr}$ & $105(66-230)$ & $70(41-154)$ \\
\hline $\mathrm{FTR}_{\text {Nar }} \%$ & $99.1(98.9 .99 .3)$ & $99.3(98.8-99.5)^{k}$ \\
\hline
\end{tabular}

Data are expressed as medians and $I Q R .{ }^{*} \mathbb{P}<0.05$ versus placebo.

\section{Systemic hemodynamic effects}

\section{Systemic hemodynamic in supine position}

At baseline, no differences in blood pressure or heart rate were observed between BNP and placebo experiments (Table 2.2). MAP was not altered by infusion of either BNP or placebo (Figure 2.1). During BNP infusion supine HR tended to rise but differences from baseline just failed to reach statistical significance $(p=0.058)$; moreover, HR responses did not differ between the two infusion experiments (Figure $2.1 ; p=0.686$ ).

Baselline values of stroke volume (SV) and CO did not differ either (Table 2.2). SV significantly decreased after BNP infusion (to $73(66-83) \mathrm{mL}$; $\mathrm{p}=0.007)$ while it did not change during placebo $(83(76-93) \mathrm{mL}$; $p=0.594$ ). This difference between the effects of BNP and placebo was statistically significant $(p=0.015$; Figure 2.2). CO significantly decreased to $4.3 \mathrm{~L}(3.7-5.2)$ during BNP infusion $(p=0.013)$, while placebo did not induce any significant change (to $4.6(4.2-5.2) \mathrm{mL} ; \mathrm{p}=0.782$ ). Expressed 
as percent change, BNP had no significant effect on $C O$ compared to placebo $(p=0.082$; Figure 2.2). TPR was not influenced by infusion of either BNP (1 880 (1 453-2 049) dyne $\left.\cdot \mathrm{s} / \mathrm{cm}^{5}\right)$ or placebo (1 755 (1 426-2 004) dyne $\left.\cdot \mathrm{s} / \mathrm{cm}^{5}\right)$.
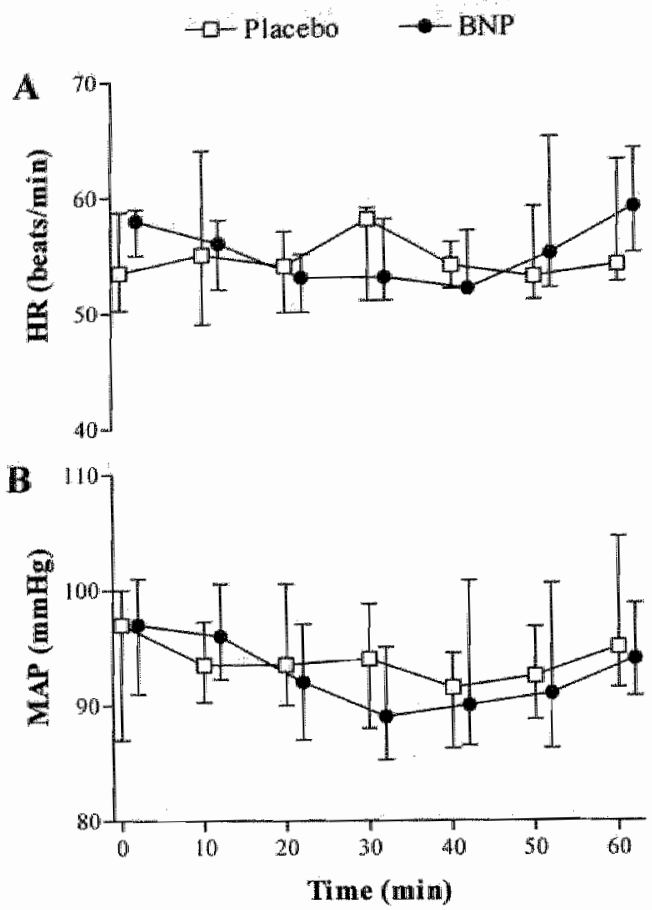

Figure 2.1 Supine heart rate $[H R$, panel $A]$ and mean anterial blood pressure $(M A P$, panel $B$ ) at baselline and every 10 minutes during 1 hour of placebo or BNP infusion. Data are presented as median and interquartile ranges. No significant changes were observed.

Influence of posture on BNP effects: MAP and HR in sitting position

Postural changes during BNP infusion were not tolerated well by four subjects. Two of these became markedly hypotensive in sitting position 15 min after completion of the BNP infusion and were unconscious for a few minutes. The other subjects "only" appeared pale and experienced dizziness and sweating in sitting position at the same moment during the protocol.

At baseline, sitting MAP and HR did not differ between BNP and placebo experiments. BNP infusion decreased sitting MAP from 92 (86-103) $\mathrm{mmHg}$ to $80(72-93) \mathrm{mmHg}(p=0.05)$. This BNP-induced fall in pressure was significantly greater than that during placebo $(p=0.028)$. HR increased significantly after BNP infusion (from $59(56-63$ ) beats/min to 
$68(60-78)$ beats $/ \mathrm{min} ; p=0.011)$ but there was no difference in percent change in HR compared to placebo infusion $(p=0.239)$.

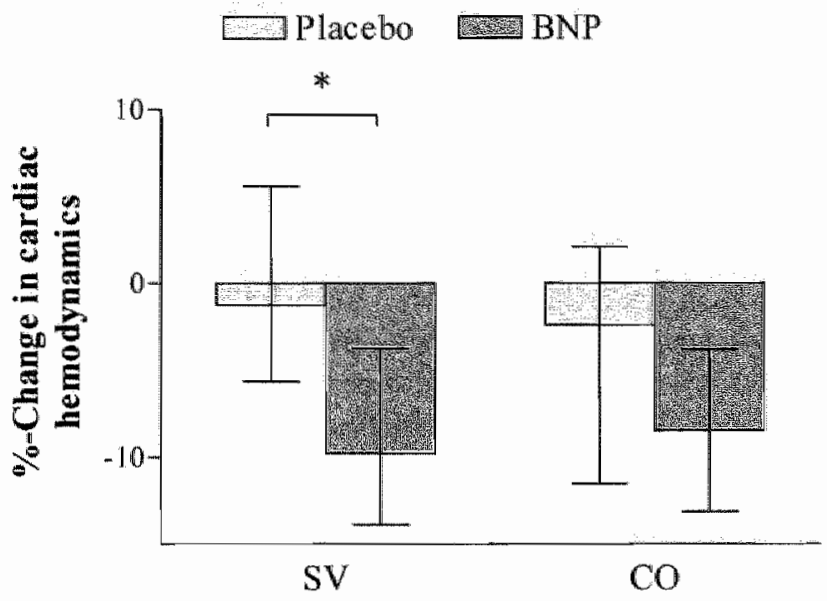

Figure 2.2 Cardiac hemodynamic responses of stroke volume (SV) and cardiac output (CO) to intravenous infusion of placebo or BNP, expressed as percent change. Data are presented as median and interquartile ranges. $* p<0.02$.

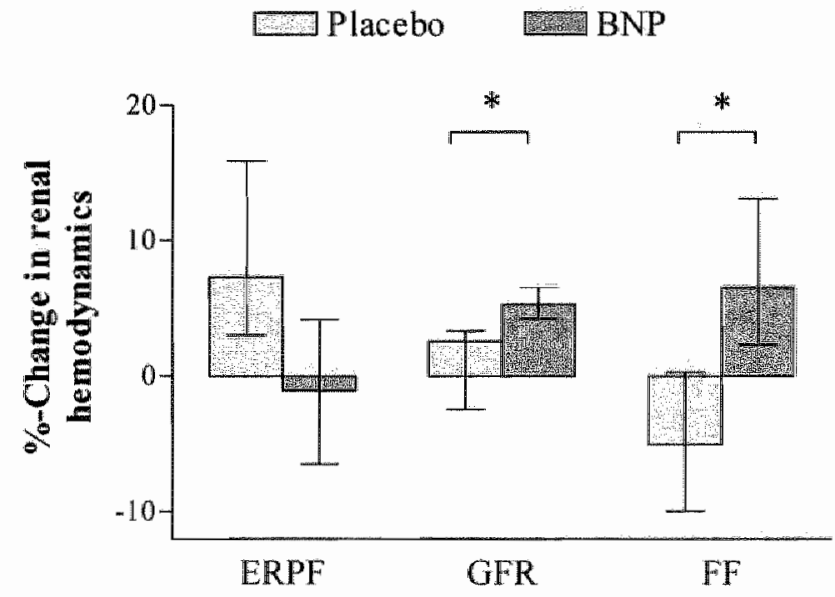

Figure 2.3 Renal hemodynamic responses of renal plasma flow (ERPF), glomerular filtration rate (GFR) and filtration fraction (FF) to intravenous infusion of placebo or BNP, expressed as percent change. Data are presented as median and interquartile ranges. ${ }^{*} p<0.03$. 


\section{Renal effects}

\section{Renal hemadynamics}

Baseline renal hemodynamics did not differ between BNP and placebo (Table 2.2). BNP significantly increased GFR after BNP infusion compared to placebo $(p=0.007$ BNP vs. placebo, Figure 2.3$)$, while ERPF did not change during either infusion. FF increased during BNP infusion to $29(26-31) \%$, while it tended to decrease during placebo infusion (to $25(21-28) \% ; p=0.022$ BNP vs. placebo, Figure 2.3).

BNP tended to increase RVR to $11526(7612-12916)$ dyne $\cdot \mathrm{s} / \mathrm{cm}^{5}$, but the difference just failed to reach statistical significance $(p=0.063)$. However, there was no difference in percent change compared to placebo infusion $(p=0.465)$. RF increased during placebo infusion to 18 $(12-20) \% ; p=0.033$, while no difference was observed in RF responses between placebo and BNP infusion $(p=0.674)$.

\section{Natriuresis and diuresis}

At baseline, $U_{N a} V$ was slightly lower and $F_{T R}$ slightly higher on the BNP than on the placebo day (Table 2.2). Compared to placebo infusion, BNP infusion resulted in a significant natriuresis and diuresis. Urinary sodium excretion in a one-hour urine collection increased to 24.1 (15.928.2) mmol during BNP $(p=0.002)$, while it did not change during placebo infusion (10.3 (7.3-13.0) $\mathrm{mmol} / \mathrm{h}$ after infusion; $\mathrm{p}=0.308$ ). Urinary volume of the one-hour urine collection significantly increased both after BNP (to 408 (360-584) $\mathrm{m}$ ) and after placebo infusion (to 225 $(176-314) \mathrm{ml}$ ) as a result of water suppletion during the renal clearance study protocol. However, the increase in urinary volume after BNP infusion was significantly greater than after placebo infusion $(p=0.002)$. $\mathrm{FL}_{\mathrm{Na}_{\mathrm{a}}}$ increased significantly from 855 (753-939) mmol/hr to 894 (803983) $\mathrm{mmol} / \mathrm{hr}$ during $\mathrm{BNP}$ infusion, while placebo infusion did not influence $F L_{\text {No. }}$. Furthermore, BNP significantly decreased $F_{T R}$ (to 97.4 $(97.1-98.2) \%)$ as compared to placebo infusion $(p=0.005)$.

\section{Microcirculation}

\section{Skin blood flow}

The effects of BNP on both basal and hyperaemic peak skin thermoregulatory) blood flow are shown in Table 2.3. As compared to placebo, BNP did not change any of the variables. Also, time to peak and duration of hyperaemia were not influenced by infusion of either BNP or placebo. Furthermore, no differences in total skin oxygen capacity at $44^{\circ} \mathrm{C}$ were observed (Table 2.3). 


\section{Nailfold microcirculation}

Although small changes in capillary density or post-ocelusive recruitment were observed during either placebo or BNP infusion, overall no significant changes between the two experiments could be observed (Table 2.3).

Table 2.3 Finger skin capillary densily, post-occlusive $(4 \mathrm{~min})$ reactive capillary recruitment and $\mathrm{SBF}$, and $\mathrm{TCPO} 2\left(44^{\circ} \mathrm{C}\right)$ before (baseline) and percentage change after $1 \mathrm{~h}$ BNP or placebo infusion (i.v.)

\begin{tabular}{lcccc}
\hline & \multicolumn{2}{c}{ Placebo } & \multicolumn{2}{c}{ BNP } \\
& $96(84-110)$ & $4(0-13)$ & $92(79-107)$ & $12^{*}(6-21)$ \\
\hline $\begin{array}{l}\text { Capillary density, } \\
\text { number/1.6 } \mathrm{mm}^{2} \text { skin }\end{array}$ & $16(9-18)$ & $-59^{*}(-87--7)$ & $9(6-15)$ & $-21(-79-38)$ \\
$\begin{array}{l}\text { Recruitment, } \\
\text { number } / 1.6 \mathrm{~mm}^{2} \text { skin }\end{array}$ & $13(10-19)$ & $-25^{*}(-45-1)$ & $13(10-23)$ & $-14(-30-15)$ \\
Rest flux, pu & $47(39-85)$ & $-22(-34-17)$ & $58(36-74)$ & $-8(-20-18)$ \\
Peak flux, pu & $47(25-61)$ & $-3(-34-9)$ & $44(35-63)$ & $-14(-25-3)$ \\
TcPo2, mmHg & & & & \\
\hline
\end{tabular}

Data are expressed as medians and IQR. * $p<0.05$ wersus baseline. No significant differences were observed between placebo and BNP.

\section{Conjunctival microcirculation}

Arteriolar, capillary, and venular density did not change significantly either during BNP or during placebo infusion (Table 2.4).

Table 2.4 Conjunctival microvascular densities $\left(\mathrm{mm} / \mathrm{mm}^{2}\right)$ at baseline and percent change in baseline values after Ih BNP or placebo infusion (i.w.)

\begin{tabular}{lcccc}
\hline & \multicolumn{2}{c}{ Placebo } & \multicolumn{2}{c}{ BNP } \\
& Baseline & $\%$-Change & Boseline & $\%$-Change \\
\hline Arteriolar density & $0.8(0.7-1.0)$ & $3(-20-29)$ & $0.9(0.8-1.1)$ & $6(-33-36)$ \\
Capillary density & $1.9(1.0-2.6)$ & $10(0-59)$ & $1.8(0.8-3.0)$ & $15(-7.32)$ \\
Venular density & $3.1(2.8-3.8)$ & $-10(-21-34)$ & $3.0(2.4-3.7)$ & $0(-14-15)$ \\
\hline
\end{tabular}

Data are expressed as medians and IQR. No significant changes were observed.

\section{Discussion}

The results of the present study suggest that low-dose BNP, when administered systemically, has predominantly central and renal hemodynamic effects, while it does not influence peripheral microcirculation, at least in skin and conjunctiva. 
In supine position, BNP infusian significantly reduced SV and tended to decrease CO. However, MAP, TPR and HR did not change significantly. Other investigators who reached similar plasma levels of BNP as we did, also observed decreases in SV without changes in CO and MAP, whereas $H R$ only increased after infusion of higher doses of BNP. ${ }^{2,3}$ These observations suggest that BNP primarily reduces preload, possibly by lowering venous return. This hypathesis is supported by our observations on the hemodynamic pattern in sitting position. Indeed, when subjects rose, they experienced orthostatic symptoms, but we also found a significant fall in MAP and CO. At the same time, HR increased rapidly, probably due to activation of the baroreceptor reflex. In literature no such influence of body position on BNP effects has been described yet.

To the best of our knowledge, our study is the first to report that low-dose infusion of BNP has no effects on skin and conjunctival microcirculation in humans. In all likelihood, this lack of effect is not due to methodological problems such as large variability of the measurements, since with the same set-up we were able to demonstrate microvascular effects of atrial natriuretic peptide (ANP). ${ }^{5}$ In that study ANP caused vasoconstriction of the microcirculation, mainly on the venular side. When we combine our observations on the systemic and the peripheral vasculature, it would seem that the most probable site of action for BNP is the venous system where it may increase the 'unstressed' volume. This would also explain, at least in part, the beneficial effects of this peptide in patients with congestive heart failure., 8 Further studies with measurements of cardiac filling pressures and venous compliance are necessary to confirm or refute this hypothesis.

Of particular interest are the effects of BNP on the kidney, In previous studies, RPF has been found to decrease ${ }^{10}$, to increase ${ }^{2}$, or to remain unchanged $^{11,12}$ during infusion of BNP. However, these studies are difficult to compare with the present one because of differences in design, doses of BNP, and infusion time. For insiance, concurrent changes in GFR and RPF only occurred when the dose of BNP exceeded $2 \mathrm{pmol} / \mathrm{kg} / \mathrm{min} .^{2,10}$ With lower doses of BNP, La Villa ef al. ${ }^{12}$ observed a natriuretic effect of BNP in the absence of changes in RPF and GFR. Our data are in line with the latter observations, even though the dose of BNP that we employed was similar to that in the studies of Jensen et al. ${ }^{10}$ and La Villa et al. ${ }^{2}$ However, Jensen et al. did not compare placebo and BNP in the same subjects, which may have introduced bias. The difference between our findings and those of La Villa et al. can probably be explained by the small number of (younger) subjects and the lower salt intake in their study as compared to ours. Although RVR tended to increase during BNP infusion, there were no differences in RVR or RF as compared to placebo. Thus, also in one of the major target organs for $B N P$, the peptide did not markedly influence arteriolar tone.

Besides the expected increase in plasma CGMP, urinary sodium excretion, and urinary volume, we observed a significant increase in 
GFR, FF and in filtered load of sodium during BNP. This suggests that BNP has a direct effect on post-glomerular vessels causing vasoconstriction and a rise in FF. Although our results do not allow to draw definite conclusions, they are compatible, at least, with the hypothesis that this vasoconstriction occurs at the level of the peritubular vessels rather than at the level of the efferent arterioles. Indeed, a rise in FF due to increased efferent arteriolar resistance would tend to enhance proximal tubular reabsorption of sodium. In fact, others have demonstrated that proximal reabsorption of sodium may be reduced by $\mathrm{BNP}^{10,11}$, which one would expect if the site of increased resistance is located further down the nephron and intrarenal physical factors raise peritubular hydrostatic pressure.

Although we did not perform a head-to-head comparison of BNP and ANP in this study, data of a previous study from our laboratory suggest that both peptides have not only different effects on microcirculatory, but also on centrall and renal hemodynamics. In that study we found that ANP had no effect on MAP and $H R$, even in sitting position. ${ }^{5}$ Furthermore, in that study ANP infusion decreased GFR and RPF and increased RVR to stimulate natriuresis and diuresis. ${ }^{5}$ Finally, ANP caused venular vasoconstriction in the microcirculation. Thus, BNP and ANP seem to have differential actions on the vascular system.

In conclusion, this study suggests that low-dose intravenous infusion of BNP in healthy subjects has predominantly central and renal hemodynamic effects, while it does not influence peripheral microcirculation. 


\section{References}

1. Yoshimura $M$, Yasue $H$, Morita $E$, al. Hemodynamic, renal, and homonal responses to brain natriuretic peptide infusion in patients with congestive heart failure. Circulation 1991; 84: 1581-1588.

2. La villa $G$, Fronzarali $C$, Lazzeri $C$, ef al. Cardiovascular and renal effects of low dose brain natriurefic peptide infusion in man. 1 Clin Endocrinol Metab 1994; 78 : 1166-1171.

3. Lazzeri $C$, La villa $G$, Bisi $G$, et al. Cardiovascular function during brain natriuretic peptide infusion in mon. Cardiology 1995; 86: 396-401.

4. World Medical Association Declaration of Helsinki. Recommendations guiding physicians in biomedical research invalwing human subjects. Cardiovasc Res 1997 35: $2-3$.

5. Houben AJ, Krekels MM, Schaper NC, Fuss-Lejeune MJ, Rodriguez SA and de Leeuw PW. Microvascular effects of atrial natriuretic peptide (ANP) in man: studies during high and low salt dief. Cardiovasc Res 1998; 39: 442-450.

6. Houben A., Slaaf DW, Huvers FC, de Leeuw PW, Nieuwenhuijzen Kruseman AC and Schaper NC. Diurnal wariations in total forearm and skin micracirculatory bload flow in man. Scand J Clin Lab linvest 1994; 54: $161-168$.

7. Cole BR, Giangiacomo J, Ingelfinger JR and Robson AM. Measurement of renal function without urine callection. A critical evaluation of the constant-infusion technic for determination of inulin and para-aminohippurate. N Engl J Med 1972; 287: $1109-11114$

8. Mills RM, LeJerntel TH, Horton DP, et al. Sustained hemodynamic effects of an infusion of mesiritide (humon b- type natriuretic peptide) in heart failure: a randomized, double-blind, placebo-controlled clinical trial. Natrecor Study Group. J Am Call Cardiol 1999; 34: 155-162.

9. Colucci WS, Elkayam U, Horton DP, et al. Intravenous nesiritide, a natriuretic peptide, in the treatment of decompensated congestive heart failure. Nesiritide Study
Group. N Engl J Med 2000; 343: 246-253.

10. Jensen KT, Carstens $J$ and Pedersen EB. Effect of BNP on renal hemadynamics, tubular function and vasoactive hormones in humans. Arn J Physiol 1998; 274:
F63 72 .

11. Jensen KT, Eiskjaer H, Carstens $J$ and Pedersen EB. Renal effects of brain natriuretic peptide in patients with congestive heart failure. Clin Sci (Colch) 1999; 96:5-15.

12. La Villa $G$, Stefani $L$, Lazzeri $C$, et al. Acute effects of physiological increments of brain natriuretic peptide in humans. Hypertension 1995; 26:628-633. 


\section{Chapter 3}

\section{Does Brain Natriuretic Peptide have a direct renal effect in human hypertensives?}

K van der Zander, AJHM Houben, AA Kroon, TKA Wierema, MJMJ Fuss-Lejeune,

D Koster, and PW de Leeuw 


\section{Abstract}

Systemic infusion of brain natriuretic peptide (BNP) stimulates natriuresis and diuresis, but has variable effects on the renal vasculature. In this study we investigated whether BNP has any direct fffects on the kidney in hypertensive patients. Three stepwise increasing doses of $B N P(60,120$, and $180 \mathrm{pmol} / \mathrm{min})$ or placebo were infused into the renal artery of 26 hypertensive patients. Renal blood flow was determined using the ${ }^{133}$ Xenon washout technique. Before and afier infusion of $\mathrm{BNP}_{5}$ arterial and venous blood samples were taken for CGMP, renin, and creatinine concentration. Intra-arterial blood pressure and heart rate were monitored continucusly. Intrarenal BNP infusion did not induce significant changes in renal blood flow, despite increases in circulating levels of CGMP. The latter, however, was not associated with changes in the cGMP gradient across the kidney. In addition, we did not find any BNP-related changes in the secretion of active renin and in creatimine extraction. At the highest dose heart rate increased after BNP infusion without a change in mean infra-arterial blood pressure. In conclusion, this study suggests that, at least in hypertensives, BNP has no direct intrarenal hemodynamic effects and that the rise in circulating CGMP without changes in net renal extraction of this second messenger is related to a primary extrarenal target of BNP. 


\section{Introduction}

Systemic infusion of brain natriuretic peptide (BNP) stimulates natriuresis and diuresis ${ }^{1.6}$, and inhibits plasma renin activity $(\mathrm{PRA})^{1-3,7,8}$, but has variable effects on the renal vasculature. Although most, but not all, studies in healthy humans reported that BNP infusion increases glomerular filtration rate $(G F R)^{1,5 \cdot 7}$, renal plasma flow (RPF) has been found to decrease ${ }^{1,7}$, to increase ${ }^{5}$, or to remain unchanged. ${ }^{3,8}$ Variations in the renovascular effects of BNP could be related to differences in BNP levels reached during the experiments, but it is equally possible that the renal changes are, in part, secondary to systemic effects. Indeed, BNP not only acts on the kidney, but also affects blood pressure, heart rate, cardiac output, and systemic vascular resistance. ${ }^{2,3,5,6,8,9}$ In those studies where changes in RPF are reported, it is important to keep in mind that such alterations may simply be due to concurrent changes in cardiac output. If, for instance, renal fraction (that is the proportion of cardiac output perfusing the kidneys) remains unaltered during systemic BNP infusion, it is unlikely that the peptide has exerted a direct effect on the renal vasculature. If, on the other hand, renal fraction increases, relative renal vasodilatation must have occurred. Unfortunately, in most studies this has not been taken into account.

Local administration of BNP in a regional vascular bed in amounts that will not have systemic effects allows for assessing whether BNP has any direct effects on certain parts of the circulation. With this approach others and we have demonstrated previously that BNP induces a dosedependent vasodilatation in forearm vasculature. ${ }^{10,11}$ In the present study, we investigated whether BNP has any direct effects on the renal circulation. To this end, we infused BNP into the renal artery of hypertensive patients who were scheduled for renal angiography. Before and during the infusion we measured renal blood flow, renin release and the extraction of creatinine, the latter being taken as a marker of glomerular filtration. We also measured concentrations of cGMP, since this second messenger may reflect BNP's activity.

\section{Methods}

\section{Subjects}

This study was performed in 26 hypertensive patients in whom renal artery stenosis (RAS) was suspected on the basis of one or more of the following criteria: treatment-resistant hypertension despite the use of at least two adequately dosed antihypertensive agents, overt peripheral 
vascular disease, the presence of an abdominal bruit or an increase in serum creatinine during angiotensin-converting enzyme inhibitor treatment. Antihypertensive medication, if any, was discontinued for three weeks before the measurements. Before hospital admission, patients were randomly allocated to a placebo group and a BNP group. Because the effects of BNP are dependent on sodium intake, we instructed half of the patients from the BNP group to follow a salt-restricted diet $155 \mathrm{mmol}$ of sodium/day) and the other half to adhere to a high-salt diet containing $220 \mathrm{mmol}$ of sodium/day during the last week before the study. Compliance with the diet was checked by measuring sodium and creatinine output in 24-hour urine collections abtained during the last day before angiography. Patients were also instructed to refrain from smoking and drinking caffeine or alcohal containing beverages for at least 48 hours before the investigations.

The Medical Ethics Committee of the Maastricht University Hospital approved the study, and all participants gave written informed consent. The investigations conformed to the principles outlined in the Declaration of Helsinki. ${ }^{12}$

\section{Experimental design}

Experiments were performed in the angiography suite of the Department of Radiology, which is equipped with an x-ray system and a gamma camera. After selective catheterisation of the renal artery and vein and before any administration of contrast material, blood samples were drawn simultaneously from the renal artery and both renal veins for determination of active plasma renin concentration (APRC), BNP, CGMP, and creatinine levels. Subsequently, mean renal blood flow (MRBF) was measured, first in the left kidney and then in the right one, by means of the ${ }^{133}$ Xenon washout technique as described earlier. ${ }^{13,14}$, Next, BNP in incremental doses of 60,120 , and $180 \mathrm{pmol} / \mathrm{min}$ or placebo (glucose $5 \%$ ) was infused into the right renal artery. Each dose was continued for 10 minutes. MRBF was measured at the end of each dosing interval. At the end of the highest dose of BNP, blood samples for determination of $A P R C, B N P, C G M P$, and creatinine levels were drawn again from the right renal vein as well as from the femoral artery. The latter was necessary to avoid contamination of blood by BNP from the infusion line. Blood samples were spun immediately and plasma was stored at a temperature of $-80^{\circ} \mathrm{C}$ until assay. Heart rate (HR) and intra-arterial blood pressure were monitored continuously during each MRBF measurement. Angiography was performed only after all measurements
had been completed.

Assay methods

APRC was measured by the IRMA method (Nichols Institute Diagnostics,
Wijchen, The Netherlands). Wijchen, The Netherlands). BNP and CGMP levels were measured by 
means of a competitive protein-binding RIA (Peninsula Laboratories Inc. RIK 9086, and IBL Hamburg RE 29071, respectively). Prior to assay, plasma samples of BNP were acidified and extracted using a SEP-Pak C18 column (Waters-Millipore). In our hands, the intra- and interassay variability of all assays were $<10 \%$. The antisera for BNP did not crossreact with the other peptides. All samples from the same subject were assayed in a single run.

\section{Calculations and statistics}

The effects of BNP on MRBF were expressed as the integrated vascullar response (IVR), defined as the area under the percent change curve and expressed in units (percent change $x$ time). A positive IVR indicates an increase in MRBF (i.e. vasodilatation), whereas a negative IVR denotes a decrease in MRBF (vasoconstriction). Net renal BNP, CGMP, and renin production or extraction was calculated as (venous concentration-arterial concentration) $\times$ MRBF. Fractional creatinine extraction was calculated as (arterial concentration-venous concentration) / arterial concentration of creatinine.

Non-parametric statistics were used for analysis. Within-group comparisons were performed using Friedman's two-way analysis of variance. Between-group analyses were performed using Kruskal-Wallis (one-way ANOVA) tests. Data are presented as medians with interquartile ranges (IQR) unless indicated otherwise. $P$ values below 0.05 denote statistical significance. The Xenon-washout technique provides accurate estimates of renal blood flow and, in our hands, has a variability of $8 \%$ for repeated measurements. Therefore, this study is able to demonstrate a $10 \%$ difference in MRBF in 10 control and 16 experimental subjects with a power of $85 \%$.

\section{Results}

Baseline clinical characteristics of the study participants are summarised in Table 3.1. Although eight patients exhibited some degree of renal artery stenosis, in none of them hemodynamically significant lesions existed. 
Table 3.1 Characteristics of the study participants

\begin{tabular}{lcc}
\hline Characteristic & Placebo & BNP \\
\hline No. (male/female) & $10(6 / 4)$ & $16(11 / 5)$ \\
Age, yr & $56(37-67)$ & $53(46-68)$ \\
Diagnosis, EH/RAS & $10 / 4$ & $12 / 4$ \\
BMi, kg/m & $26.7(22.6-28.0)$ & $25.3(23.3-27.2)$ \\
MAP, mintg & $136(120-144)$ & $140(123-1.49)$ \\
HR, beats/min & $77(66-85)$ & $70(60-75)$ \\
Urinary sodium excretion, mmol/24h & $65(41-80)$ & LS: $68(48-83)$ \\
& & HS: $204(161-244)$ \\
\hline
\end{tabular}

Data are presented as median and interquartile ranges.

$L S=$ low salt diet. $H S=$ high salt diet

\section{Effect of BNP or placebo infusion on renal blood flow}

At baseline, mean renal blood flow (MRBF) did not differ significantly between the placebo and the BNP group $(p=0.262$; Table 3.2). Likewise, no differences in flow could be detected between patients on a low-salt diet and those on a high-salt diet. Responses did not differ either between kidneys with or without renal artery stenosis. Infusion of placebo did not induce significant changes in MRBF $(p=0.976$; Table 3.2). However, MRBF was not altered by BNP either $(p=0.204$; Table 3.2). The latter was true both in the low and in the high-salt group $(p=0.308$, and $\mathrm{p}=0.366$ respectively). Furthermore, changes in IVR during BNP infusion $(1.8[-11.3-37.0])$ did not differ significantly from zero $(p=0.234)$. In addition, there was no difference in IVR among the BNP and placebo group $(p=0.856)$. No relation was seen between IVR and baseline renal flow.

Table 3,2 Absolute flow (mL/100g/min) at baseline and after BNP (or placebo) infusion

\begin{tabular}{lllll}
\hline Infusion of & baseline & $60 \mathrm{pmol} / \mathrm{min}$ & $120 \mathrm{pmol} / \mathrm{min}$ & $180 \mathrm{pmol} / \mathrm{min}$ \\
\hline Placebo & $241(163-290)$ & $233(156-297)$ & $263(162-314)$ & $251(172-305)$ \\
BNP & $166(111-248)$ & $190(137-236)$ & $176(166-260)$ & $184(137-206)$ \\
\hline
\end{tabular}

Plasma levels of BNP, cGMP, renin and creatinine

Placebo infusion did not alter any of the measured variables or their gradients across the kidney. Intrarenal BNP infusion not only caused the expected increase in venous levels of this peptide, but also enhanced arterial BNP levels (both $p<0.01$; Table 3.3). Parallel with the increase in plasma BNP, we observed a rise in CGMP, both in arterial and in venous renal blood samples (both $p<0.01$ ). The net BNP and cGMP gradients across the kidney, however, did not change during BNP infusion $(p=0.182$ and $p=0.875$, respectively). Moreover, BNP infusion did not 
induce significant changes in net APRC production and creatinine extraction (Figure 3.1). Fractional creatinine extraction did not change either (Table 3.3). When the placebo and the BNP group were compared, no differences were observed in APRC production or (fractional) creatinine extraction between both groups.

Table 3.3 Plasma levels of BNP, cGMP, APRC, and creatinine at baseline and after BNP infusion

\begin{tabular}{lcccc}
\hline Variable & \multicolumn{2}{c}{ Baseline } & \multicolumn{2}{c}{ After BNP infusion } \\
& Arterial & Venous & Arterial & Venous \\
\hline $\mathrm{BNP}$, & 83.6 & 82.1 & $510.8^{*}$ & $577.3^{*}$ \\
$\mathrm{pg} / \mathrm{mL}$ & $(60.0-149.6)$ & $(53.8-132.1)$ & $(318.6-761.0)$ & $(271.0-880.5)$ \\
$\mathrm{cGMP}$, & 6.8 & 5.6 & $10.3^{*}$ & $7.9^{*}$ \\
$\mathrm{pmol} / \mathrm{mL}$ & $(5.7-9.3)$ & $(2.9-7.3)$ & $(6.5-15.8)$ & $(5.2-9.7)$ \\
$\mathrm{APRC}$, & 19.0 & 26.5 & 26.9 & 26.4 \\
$\mu \mathrm{U} / \mathrm{mL}$ & $(13.4-40.1)$ & $(17.2-39.1)$ & $(14.5-36.8)$ & $(17.1-38.1)$ \\
$\begin{array}{l}\text { Creatinine, } \\
\mathrm{mmol} / \mathrm{mL}\end{array}$ & 79.5 & 70.5 & 78.5 & 68.0 \\
fractional & $(61.5-113.3)$ & $(57.0-89.3)$ & $(58.3-108.5)$ & $(58.8-81.3)$ \\
creatinine \\
extraction
\end{tabular}

$* p<0.01$ versus baseline.

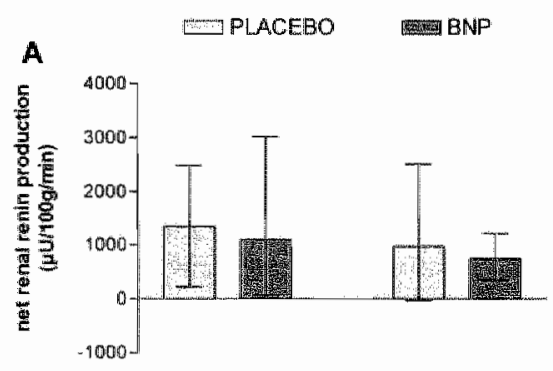

B

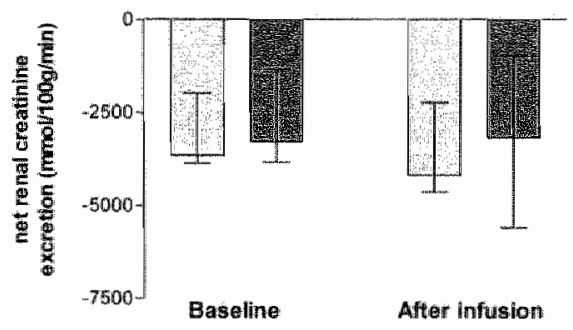

Figure 3.1 Net renal renin (panel A) and creatinine (panel B) production/extraction at baseline and after placebo or BNP infusion. Data are presented as median and interquartile ranges. No changes were abserved. 


\section{Blood pressure and heart rate}

Mean intra-arterial pressure (MAP) did not change during either placebo or BNP infusion $(p=0.475$ and $p=0.650$, respectively; Figure 3.2$)$. Whereas heart rate did not change during placebo infusion ( $p=0.505$ ), it increased significantly from 67 beats per minute at baseline to 72 beats per minute at the highest dose of BNP infusion $(p=0.011$; Figure 3.2). The difference in heart rate responses between the placebo and the BNP group was, however, not statistically significant $(0.05<p<0.10)$.

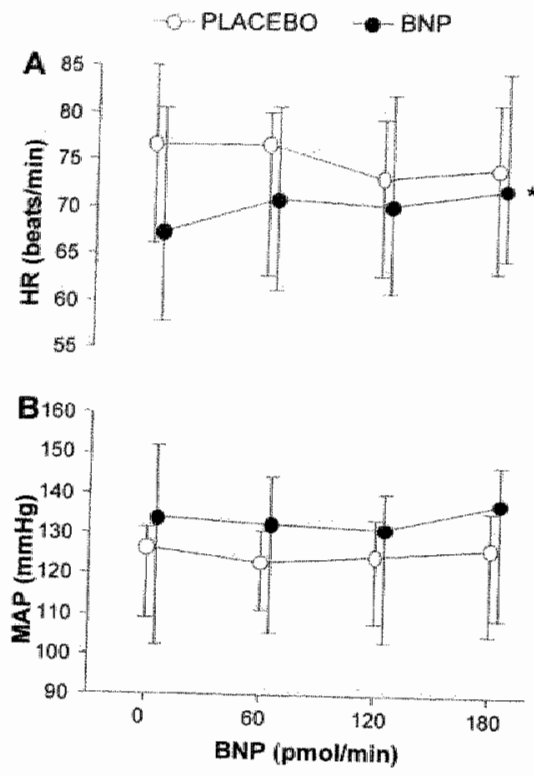

Figure 3.2 Heart rate $(H R$, panel $A)$ and mean intra-arterial bload pressure (MAP, panel B) at baseline and after infusion of placebo (open circles) or BNP (closed circles). Data are presented as median and interquartile ranges. ${ }^{*} p<0.02$, $B N P$ infusion versus baseline.

\section{Discussion}

The present study shows that intrarenal BNP infusion in supine hypertensive patients does not induce significant changes in renal blood flow, despite increases in circulating levels of cGMP. In addition, we did not find BNP-related changes in the secretion of active renin and in creatinine extraction.

At baseline, median BNP levels of our hypertensive patients were almost 3-times higher than those we measured before in the forearm of healthy subjects. ${ }^{15}$ This difference corroborates previous studies that 
which may be related to left ventricular hypertrophy, and/or diastalic dysfunction. ${ }^{16,17}$

Intra-arterial infusion of BNP caused an approximately 7 -fold increase in renal venous BNP levels. Although this increase is to be expected, we also observed a comparable rise in arterial plasma BNP levels, indicating overflow of BNP into the systemic circulation. The slight increase in heart rate at the highest dose of BNP is compatible with this notion and, in the absence of changes in mean arterial blood pressure may point towards mild baroreceptor activation. The elevated BNP levels at the end of the infusion period approached but mostly exceeded the venous levels reached in systemic infusion studies. ${ }^{113,8}$ However, in this respect a simple comparison is not justified because the BNP levels reported here were obtained at the end of a dose-response study. Thus, in our experiment, the systemic vasculature must have been exposed to lower concentrations of BNP during the greater part of the study. Despite higher circulating BNP, the gradient of BNP across the kidney did not change. In fact, we found no evidence for renal extraction of BNP, neither at baseline nor during $\mathrm{BNP}$ infusion. This casts doubt on the supposition of a direct renal effect of BNP.

In a previous study, we demonstrated that intra-arterial BNP infusion into the human forearm induces a dose-dependent vasodilatation, via an increase in cGMP and c-type natriuretic peptide (CNP) levels. ${ }^{15}$ The second messenger cGMP is thought to be generated by activation of the natriuretic peptide receptor $A$ (NPR-A) and/or via nitric oxide (NO) production. The present study shows that BNP infusion, indeed, induced CGMP release in our patients. Both renal venous and arterial CGMP plasma levels rose significantly after BNP infusion, but there was no change in the net renal cGMP gradient, with even a tendency for uplake rather than release. Taken together, these observations suggest that BNP by itself is not able to trigger CGMP release intrarenally and this may explain why we failed to observe renall vasodilatation. In addition, it suggests that cGMP was produced somewhere else in the cardiovascular system. Other variables to assess the effect of BNP, i.e. creatinine extraction (as marker for filtrating capacity) and renin secretion, also showed no differences after BNP infusion.

Another explanation for the lack of variation in MRBF may be that BNP, except for inducing vasodilatation, simultaneously stimulates a vasoconstrictor mechanism within the kidney and that any locally produced CGMP is excreted into the urine. Indeed, it has been demonstrated before that a close functional relationship exists between BNP and intrarenal endothelin-1 (ET-1) production. ${ }^{18}$ Apart from being a potent vasoconstrictor, ET-1 exhibits intrarenal natriuretic activity. In the present study we did not measure urine indices, but in literature systemic infusion of BNP is accompanied by an increased urinary excretion of $\mathrm{ET}$ 1, cGMP and sodium, without changes in plasma ET-1, plasma sodium, and plasma creatinine. ${ }^{18}$ Our previous finding that BNP is a mild dilator 
compared to equimolar doses of ANP supports the concept of a balance between vasodilating and vasoconstrictor forces. ${ }^{10}$ An additional argument may be that in in-vitro experiments, we were unable to demonstrate consistently BNP-induced vasodilatation in human and rat tissue. In phenylephrine-preconstricted human omental and pericardial resistance arteries, and rat mesenteric, renal, saphenal, and uterine arferies, in only 4 out of 14 experiments $10 \mathrm{nM}$ BNP (human BNP-32 and rat BNP-45) caused a relaxation. On the contrary, $10 \mu \mathrm{M}$ acethylcholine induced dilatation in all experiments (unpublished observations).

\section{Limitations}

One could argue that the Xenon-washout technique is not sensitive enough to detect increases in renal blood flow. However, in earlier studies we showed that both acethylcholine and adenosine induce renal vasodilatation, and that this was adequately defected with our method. ${ }^{19,20}$ So, if there was any (net) effect of BNP, it must, at least, have been very small. Another limitation of the present study is that, for ethical reasons, we could not study healthy subjects. It is well known that in diseases such as hypertension, several mechanisms may be altered and dysfunctional. Therefore, it is possible that BNP produces greater renal vasodilatation in normals and that our patients merely exhibited decreased sensitivity for this peptide. In addition, we cannot exclude the possibility that BNP-induced changes may be more pronounced in the upright position. Furthermore, creatinine extraction may not be the best marker for evaluating changes in GFR. Finally, we want to stress that so far our findings are only applicable to those hypertensive patients who fulfilled our selection criteria, i.e. the ones with treatment-resistant hypertension and/or target organ damage.

\section{Perspectives}

Further investigations are needed to determine BNP binding sites in the kidney, and the role of urinary CGMP excretion. In addition, more research is needed to investigate the role of ET-1 as a mediator of BNP. induced renal effects. Finally, the hypothesis needs to be tested that renal effects of BNP can only be elicited in the face of systemic hemodynamic changes. 


\section{References}

1. Jensen KT, Carstens J, Pedersen EB. Effect of BNP on renal hemodynamics tubula function and vasoactive hormones in humans. Am J Physiol. 1998; 274: F63-72.

2. Holmes SJ, Espiner EA, Richards AM, Yandle TG, Frampton C. Renal, endocrine, and hemodynamic effects of human brain natriuretic peptide in normal man. $J \mathrm{Clin}$ Endocrinol Metab. 1993; 76: 91-96.

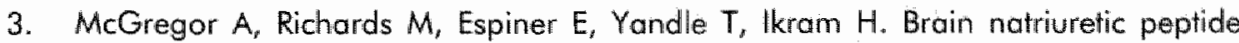
administered to man: actions and metabolism. J Clin Endocrinol Metab. 1990; 70: 1103-1107.

4. Yasue $H$, Yoshimura $M$. Natriuretic peptides in the treatment of heart failure. $J$ Card Fail. 1996; 2 : $5277-285$.

5. La Villa $G$, Fronzarali $C_{v}$ Lazzeri $C$, Parciani $C$, Bandinelli $R$, Vena $S$, Messeri $G$, Franchi $F$. Cardiovascular and renal effects of low dose brain natriuretic peptide infusion in man. J Clin Endocrinal Metab. 1994; 78: 1166-1171.

6. Yoshimura $M$, Yasue $H$, Marita $E_{r}$ Sakaino $N$, Jougasaki M, Kurase M, Mukoyama M, Salto $Y$, Nakao K, Imura H. Hemodynamic, renal, and hormonal responses to brain natriuretic peptide infusion in patients with congestive heart failure. Circulation. 1997;84: 1581-1588.

7. Jensen KT, Eiskjaer H, Carstens J, Pedersen EB. Renal effects of brain natriuretic peptide in patients with congestive heart failure. Clin Sci (Colch). 1999; 96: 5-15.

8. La Villa G, Stefani L, Lazzeri $C$, Zurli $C$, Guerra CT, Barletta $G$, Bandinelli R, Strazzulla $G$, Franchi $F$. Acute effects of physiological increments of brain natriuretic peptide in humans. Hypertension. 1995; 26: 628-633.

9. Lazzeri C, Franchi F, Parciani C, Fronzaroli C, Casini Raggi V, De Feo ML, Mannelli M, Cersosimo RM, Lo Villa G. Systemic hemodynamics and renal function during brain natriuretic peptide infusion in patients with essential hypentension. Am $J$ Hypertens. 1995; 8: 799.807.

10. wan der Zander K, Houben AJ, Kroon AA, de Leeuw PW. Effects of brain natriuretic peptide on forearm vasculature: comparison with atrial natriurefic peptide. Cardiovasc Res. 1999; 44: 595-600.

11. Nakamura $M$, Arakawa $N$, Yoshida $H$, Makita $S$, Niinuma $H$, Hiramori $K$. Vasodilatory effects of B-type natriuretic peptide are impaired in patients with chronic heart failure. Am Heart J. 1998; 135: 414-420.

12. World Medical Association Declaration of Helsinki. Recommendations guiding physicians in biomedical research involving human subjects. Cardiovasc Res. 1997; 35: $2-3$.

13. Wierema TK, Houben AJ, Kroon AA, Koster D, van der Zander $K$, wan Engelshoven $J M$, de Leeuw PW. Nitric oxide dependence of renal blood flow in patients with renal artery stenosis. \Arn Soc Nephral. 2001; 12:1836-1843.

14. Ladefoged J. Measurements of the renall blood flow in man with the 133 xenon wash-out technique. A description of the method. Scand J Clin Lab Invest. 1966; 18: $299-315$. 
15. wan der Zander K, Houben AJ, Kroon AA, De Mey IG, Smits PA, de Leeuw PW. Nitric oxide and potassium channels are involved in brain natruretic peptide induced vasodilatation in man. J Hypertens. 2002, 20:493-499.

16. Kohno $M$, Horio $T$, Yakokawa $K$, Murakawa $K$, Yasunari $K_{n}$ Akioka $K_{n}$ Tahara $A$, Toda I, Takeuchi K, Kurihara $N$, el al. Brain natriuretic peptide as a cardiac homome in essential hypertension. Am J Med. 1992; 92:29-34.

17. Cheung BM. Plasma concentration of brain natriuretic peptide is related to diastolic function in hypertension. Clin Exp Pharmacal Physiol. 1997; 24: $966-968$.

18. De Feo ML, La Villa G, Lazzeri $C$. Tosti-Guerra $C_{s}$ Becorpi A, Pupilli $C$, Mannelli $M$. Urinary endothelin- 1 excretion is enthanced by low-dose infusion of brain natriumetic peptide in normal humans. Hypentension. 1997; 29:70-74.

19. Wierema TK, Houben AJ de Leeuw PW. Acetylcholine-induced wasodilatation in the human hypertensive kidney: inhibition by muscarinic receptor antagonism. I Hypertens. 1997; 15: 1649-1651.

20. Wierema TK, Postma CT, Houben AJ, Kroon AA, Thien T, Smits P, de Leeuw PW. Adenosine-induced renal vasodilatation is prolonged in renal artery stenosis. J Hypertens. 1998; 16: 2109-2112. 


\section{Chapter 4}

\section{Selective endothelin-1 B receptor blockade inhibits basal, but not BNP-induced natriuresis}

K van der Zander, DJ Webb, NR Johnston, JGR De Mey, AJHM Houben, PW de Leeuw 


\section{Abstract}

Brain natriurefic peptide (BNP) and endothelin (ET-1) both exhibit natriuretic activity within the human kidney. Furthermore, they both act partly through activation of the endothelium NO-pathway. Since endothelin-1 may cause vasodilatation and natriuresis via stimulation of the ET- 1 B receptor, the aim of the present study was to investigate in healthy subjects whether renal ET-B receptors participate in the renal actions of BNP.

In this placebo-contralled, cross-over study we infused BNP $(4 \mathrm{pmol} / \mathrm{kg} / \mathrm{min})$ or placebo (i.w.) for 1 hour, wh or without co-infusion of the endothelin $B$ receptor antagonist $B Q$. 788 (50 nmol/min) for $15 \mathrm{~min}$ on 4 separate days, in 5 healthy subjects (mean age $60 \pm 5 y$.). Cardiac output was studied before and after infusion, using echocardiagraphy. Furthermore, during infusion we measured effective renal plasma flow (ERPF), and glomerular filtration rate (GFR) using PAH/inulin clearance. Blood pressure and heart rate (HR) were monitored as well. Urine and plasma samples were taken every hour to measure diuresis, natriuresis, CGMP and ET-1 levels.

BQ-788 decreased natriuresis, while BNP increased natriuresis, diuresis, GFR, FF and filtered load, without thanging ERPF and filtration fraction. Neither BQ-788 or BNP altered cardicac autput, blood pressure and heart rate. Combination of BNP and $B Q-788$ infusion showed no differences in hemodynamics and natriuresis os compared to BNP infusion alone.

The present study shows that selective ET-B receptor antagonism by itself decreases renal sodium excretion, but that it has no effect on the BNP-induced natriuresis and glomerular filtration rate. 


\section{Introduction}

Brain natriuretic peptide (BNP), one of the family of natriuretic peptides, stimulates natriuresis and diuresis, but the renal mechanisms that are involved remain unclear. Increases in glomerular filtration rate (GFR) and renal plasma flow (RPF) could represent the intrarenall forces, which explain the enhanced natriuresis occurring during systemic BNP infusion. However, La Villa et al. found a natriuretic effect of BNP' in the absence of changes in GFR and RPF in healthy subjects." Furthermore, we observed in hypertensive patients that intrarenal BNP infusion does not induce significant changes in renal blood flow or creatinine extraction (as a marker of glomerular filtration). ${ }^{2}$ This suggests that BNP primarily acts at the tubular level in the kidney. On the other hand, it may be that BNP, except for inducing renal vasodilatation, simultaneously stimulates a vasoconstrictor mechanism with the net effect that RPF remains constant. Indeed, it has demonstrated before that a close relationship exists between BNP and intrarenal endothelin-1 (ET-1) production. ${ }^{3}$ Apart from being a potent vasoconstrictor, ET-1 exhibits intrarenal natriuretic activity independently of changes in filtered load. ${ }^{4}$ The role of ET- 1 in the kidney may even be dissociated from circulating ET-1. In fact, De Feo et al. demonstrated that systemic infusion of BNP is accompanied by increased urinary excretion of ET-1, cGMP and sodium, without changes in plasma $\mathrm{ET}-1 .^{3}$

ET-1 acts in an autocrine and paracrine manner on two subtypes of ET receptors, termed ET-A and ET-B. These receptors are located on vascular smooth muscle cellls and binding of ET- 1 to these sites results in sustained vasoconstriction. However, ET-B receptors are also present on endothelial cells where their activation leads to production of $\mathrm{NO}$ and vasodilatator prostanoids, and subsequent vasodilatation. In a previous study, we demonstrated that BNP acts partly via the production of NO. ${ }^{5}$ Thus, it may be that the close relationship between BNP and ET-1 production in the kidney means that ET- 1 mediates (part of) the effects of BNP via the ET-B receptor. If this were the case, this would introduce an interesting novel interaction for therapeutical interventions. Indeed, currently a number of drugs are under investigation, which either inhibit the enzyme that degrades natriuretic peptides (neutral endopeptidase inhibitors) or block endothelin receptors. Both types of agents are evaluated for their potential in the treatment of cardiovascular disease. Concurrent administeration of a neutral endopeptidase inhibitor and a selective ET-A receptor antagonist would greatly enhance BNP's effect on the kidney if ET-B receptors were to mediate these effects. The aim of the present study, therefore, was to test this hypothesis by investigating whether renal ET-B receptors are involved in the renal actions of BNP. To 
this end, we studied the cardiac and renal effects of BNP with and without co-infusion of the ET-B receptor antagonist BQ-788 in a group of healthy subjects. Because the pathophysiological role of BNP becomes particularly evident in older patients we selected for this study only individuals above age 50 years.

\section{Methods}

\section{Subjects}

Experiments were performed in 5 healthy volunteers. During the week prior to the measurements, all subjects adhered to a $175 \mathrm{mmol} \mathrm{Na}^{+}$containing dief so as to minimize variations in results due to differences in salt intake. Compliance with the diet was checked by measuring sodium and creatinine output in 24-hour urine collections obtained during the lasi 24 hours before the experimental day. None of the subjects used any medication (including non-steroidal anti-inflammatory drugs) during the two weeks prior to the measurements. In addition, they had to refrain from smoking and drinking caffeine or alcohol containing beverages for at least 12 hours before the experiments, which started at 8:30 a.m. after an overnight fast. The Medical Ethics Committee of the Maastricht University Hospital approved the study, and all participants gave written informed consent. The investigations conformed to the principles outlined in the Declaration of Helsinki. ${ }^{6}$

\section{Experimental design}

The study was designed as a four way crossover trial. All volunteers were studied on four separate occasions (at least two days apart), during which they received in random order (double blind) an i.v. infusion of either vehicle (glucose $5 \%$ ), BNP, a combination of placebo with $B Q-788$ or $B N P$ combined with $B Q-788$. Experiments were performed in a quiet, temperature-controlled room. Precautions were taken to minimize external disturbances. Subjects remained supine throughout the experiments. A 20-gauge catheter was inserted into the antecubital vein of both arms. One was connected to a 3-way tap for infusion of placebo, BNP, BQ-788 (both from Clinalfa, Ethifarma Nederland BV, The Netherlands) and para-amino hippurate (PAH)/inulin (for measuring renal hemodynamics), while the other was used for blood sampling. To ensure adequate diuresis, subjects consumed $200 \mathrm{~mL}$ of water every hour until the last blood samples had been drawn. At $f=0$ min the $\mathrm{PAH} /$ inulin infusion was started and an echocardiogram was taken. At $t=120 \mathrm{~min}$ the intravenous infusion of either placebo (glucose $5 \%$ ), BNP (4 pmol $/ \mathrm{kg} / \mathrm{min}$ ), a combination of placebo with $B Q-788(50 \mathrm{nmol} / \mathrm{min}$ ) or $\mathrm{BNP}$ combined with $\mathrm{BQ}-788$ was started. Based on our previous 
studies, these relatively low doses of BNP and $B Q-788$ were suspected to influence renal, but not systemic hemodynamics. "Infusion of BQ-788 stopped at $t=135 \mathrm{~min}$. At $t=180 \mathrm{~min}$ (i.e. after one hour of placebo or BNP infusion), a second echocardiogram was performed. Blood pressure and heart rate (HR) were measured before and after the measurements in sitting position, and at 10-minute intervals during the infusion in supine position. Blood samples were drawn at $t=0, t=120$, and $t=180$ min for PAH and inulin and at $t=120$ and $t=180 \mathrm{~min}$ for determination of hematocrit, CGMP and ET-1. Urine samples for measurement of sodium, CGMP and ET- 1 were collected at $t=60, t=120$, and $t=180 \mathrm{~min}$ (immediately after blood sampling).

\section{Measurements}

Systolic blood pressure (SBP), diastolic blood pressure (DBP), and HR were measured by an automatic oscillometric device (Dinamap Vital Signs Monitor 1846, Critikon). CO was measured by echocardiography and total peripheral resistance (TPR) was calculated as (MAP/CO) * 80 and expressed in dyne $\mathrm{s} / \mathrm{cm}^{5}$.

Renal hemodynamics, i.e. effective renal plasma flow (ERPF) and glomerular filtration rate (GFR), were measured as the clearance of PAH (MSD, West Point, PA, USA) and inulin (Inutest, Laevosan Gesellschaft, Linz, Austria) respectively, during continous infusion of these substances. ${ }^{8}$ Both GFR and ERPF were corrected for body surface area and expressed as $\mathrm{mL} /\left(\mathrm{min} \cdot 1.73 \mathrm{~m}^{2}\right)$. Effective renal blood flow (ERBF) was calculated by the following formula: $E R B F=E R P F /(1$-hematocrit). Filtration fraction (FF) was calculated as GFR/ERPF. Renal vascular resistance (RVR) was calculated as (MAP/ERBF) ${ }^{*} 80000$ and expressed in dyne $\cdot \mathrm{s} / \mathrm{cm}^{5}$. Renal fraction (RF) was calculated as (ERBF/CO) * 100\%. Filtered load (FL) is calculated as GFR * $60^{*}\left[\mathrm{Na}^{+}\right]$plasma and expressed in $\mathrm{mmol} / \mathrm{hr}$. Fractional tubular reabsorption (FTR) is calculated as ( $\left(F L-U_{\text {Nat }} V\right) / F L$ ) * $100 \%$, where $\mathrm{U}_{\mathrm{Na}} \mathrm{V}$ stands for the amount of $\mathrm{Na}^{+}$excreted in the urine, and expressed also in $\mathrm{mmol} / \mathrm{hr}$.

\section{Assay methods}

PAH and inulin levells were measured by means of a spectrophotometer. cGMP levels were measured with a competitive protein-binding RIA (IBL Hamburg RE 29071). In our hands, the intra- and interassay variability of all assays was $<10 \%$. ET-1 was determined by standard RIA (Peninsula Laboratories Europe).

\section{Statistics}

As their distribution was not normal, data are presented as medians with interquartile ranges (IQR). The primary outcome variable in this study was the difference in natriuretic response during combined $B N P / B Q-788$ 
infusion relative to that during BNP alone. Secondary analyses comprised the effects of the interventions on renal hemodynamics. For each intervention, we calculated the percent change relative to pre-infusion values. Friedman's test (non-parametric two-way ANOVA) was used for analysis of multiple related samples (between visits) and Wilcoxon paired sign test for paired analysis (both within one visit and between visits). $P$ values below 0.05 denote statistical significance. In case a Friedman's test demonstrated statistical significance, post hoc analyses was performed by a Wilcoxon paired sign test. Based on previous experiments we calculated that this study is able to demonstrate a $10 \%$ difference in any of the test variables with a power of $80 \%$ in 5 experimental subjects.

\section{Results}

Baseline clinical characteristics of the study participants are summarised in Table 4.1.

Table 4.1 Characteristics of the five study participants (median and IQR).

\begin{tabular}{lc}
\hline Characteristic & Value \\
\hline No. (male/female) & $5(3 / 2)$ \\
Age, year & $60(58-61)$ \\
$\mathrm{BMl}, \mathrm{kg} / \mathrm{m}^{2}$ & $26.9(25.8-27.4)$ \\
$\mathrm{SBP}, \mathrm{mmHg}$ & $121(120-126)$ \\
$\mathrm{DBP}, \mathrm{mmHg}$ & $81(79-8.4)$ \\
$\mathrm{HR}$, beats/min & $60(59-64)$ \\
Urinary sodium excretion, mmol/24h & $168(115-234)$ \\
\hline
\end{tabular}

(blood pressure is the mean of 3 measurements by sphygmomanometer in sitting position)

BMI, Bady Mass Index; SBP, Sytolic Blood Pressure; DBP, Diastalic Blood Pressure; HR, Heart Rate.

\section{Plasma and urinary levels of CGMP and endothelin-1}

At baseline, cGMP plasma levels did not differ between visits $(p=0.564$; Table 4.2). Both infusion of BNP and the combination of $B N P$ and $B Q$ 788 significantly increased the CGMP plasma level to $14.8(13.5-19.8)$ $\mathrm{pmol} / \mathrm{mL}$ and $22.5(21.5-29.5) \mathrm{pmol} / \mathrm{mL}$ respectively $(\mathrm{p}<0.05)$, while placebo infusion with and without $B Q-788$ had no significant effect on CGMP plasma levels. The percent rise in plasma cGMP was significantly greater with infusion of BNP with or without co-infusion of BQ-788 (296 $(168-418) \%$ and $113(92-370) \%$ respectively) as compared to placebo 
with $(35(-27-55) \%)$ or without $(29(-11-47) \%)$ co-infusion of $B Q-788$ $(p<0.05)$.

Baseline plasma ET- 1 levels did not differ between visits $(p=0.098$; Table 4.2). Both infusion of placebo and BNP significantly increased ET-1 levels to $3.4(3.0-3.9) \mathrm{pg} / \mathrm{mL}$ and $2.8(2.7-4.1) \mathrm{pg} / \mathrm{mL}$ respectively $(p<0.05)$, while infusion of placebo or BNP co-infused with BQ-788 had no significant effect on ET-1 plasma levels.

Whereas no effects, whatsoever, were seen with respect to urinary ET-1 excretion, changes in urinary excretion of CGMP followed the pattern of plasma levels.

Table 4.2 Baseline data of all variables (supine) before infusion of placebo, placebo combined with $B Q-788$, BNP, or BNP combined with BQ-788.

\begin{tabular}{|c|c|c|c|c|}
\hline Variable & Placebo & Placebo/BQ.788 & BNP & $\mathrm{BNP} / \mathrm{BQ}-788$ \\
\hline \multirow[t]{2}{*}{ Plasma cGMP, pmol//mL } & 5.2 & 5.7 & 6.0 & 5.6 \\
\hline & $(4.4-7.9)$ & $(5.2-10.2)$ & $(4.2-7.6)$ & $(4.7-10.1)$ \\
\hline \multirow[t]{2}{*}{ Plasma ET-1, pg/mL } & 2.7 & 2.9 & 1.8 & 3.0 \\
\hline & $(2.5-3.0\}$ & $(2.5-3.1)$ & $(0.6-2.7)$ & $(2.3-4.5)$ \\
\hline \multirow[t]{2}{*}{ MAP, $\mathrm{mmHg}$} & 97 & 91 & 97 & 98 \\
\hline & $(95-103)$ & $(87-97)$ & $(92-102)$ & $(88.100)$ \\
\hline \multirow{2}{*}{$H R_{,}$beats/min } & 52 & 56 & 59 & 56 \\
\hline & $(51-59)$ & $(48-58)$ & $(55-65)$ & $(48.58)$ \\
\hline \multirow[t]{2}{*}{$\mathrm{SV}, \mathrm{mL}$} & 89 & 83 & 82 & 87 \\
\hline & $(84-109)$ & $(74-96)$ & $(70-99)$ & $(72-96)$ \\
\hline \multirow[t]{2}{*}{$C O, L$} & 5.4 & 4.7 & 4.9 & 4.4 \\
\hline & $(4.2-6.8)$ & $(3.6-6,1)$ & $(3.7-6.2)$ & $(4.0-5.9)$ \\
\hline \multirow[t]{2}{*}{ TPR, dyne $\cdot \mathrm{s} / \mathrm{cm}^{5}$} & 1535 & 1432 & 1759 & 1547 \\
\hline & $(895-1408)$ & $\left(\begin{array}{lll}1 & 238-2 & 050\end{array}\right)$ & $(1216-2313)$ & $(1308-1950)$ \\
\hline \multirow[t]{2}{*}{$\mathrm{ERPF}, \mathrm{mL} /\left(\mathrm{min} \cdot 1.73 \mathrm{~m}^{2}\right)$} & 458 & 434 & 432 & 423 \\
\hline & $(333-537)$ & $(367.474)$ & $(414-483)$ & $(335-477)$ \\
\hline \multirow[t]{2}{*}{$\mathrm{ERBF}, \mathrm{mL} /\left(\mathrm{min} \cdot 1.73 \mathrm{~m}^{2}\right)$} & 755 & 750 & 751 & 693 \\
\hline & $(575.959)$ & $(609-871)$ & $(696-903)$ & $(566.884)$ \\
\hline \multirow[t]{2}{*}{$\mathrm{GFR}, \mathrm{mL} /\left(\mathrm{min} \cdot 1.73 \mathrm{~m}^{2}\right)$} & 1106 & 86 & 109 & 91 \\
\hline & $(94-132)$ & $(82.102)^{a}$ & $(95-123)$ & $(79-101)^{a}$ \\
\hline \multirow{2}{*}{ FF, $\%$} & 25 & 21 & 23 & 21 \\
\hline & $(22-30)$ & $(19-25)$ & $(22-28)$ & $(20-26)$ \\
\hline \multirow[t]{2}{*}{$\mathbb{R V R}_{x}$ dyne $\cdot \mathrm{s} / \mathrm{cm}^{\mathrm{s}}$} & 9314 & 10649 & 7886 & 11769 \\
\hline & $(4933-9037)$ & $(6428-11465)$ & $(6701-10969)$ & (6 443-12938) \\
\hline \multirow[t]{2}{*}{$\mathrm{RF}_{n} \%$} & 17 & 17 & 21 & 16 \\
\hline & $(11-22)$ & $(14-21)$ & $(14.23)$ & $(1.4 .21)$ \\
\hline \multirow[t]{2}{*}{$\mathrm{U}_{\mathrm{k}, \mathrm{a}} \mathrm{V}_{\mathrm{r}} \mathrm{mmal} / \mathrm{hr}$} & 8.1 & 10.3 & 6.6 & 19.1 \\
\hline & $(7.8 \cdot 72.3)$ & $(7.1-16.7)$ & $(5.9-10.0)$ & $(4.8-21.4)$ \\
\hline \multirow[t]{2}{*}{$\mathrm{V}_{s} \mathrm{~mL} / \mathrm{hr}$} & 70 & 160 & 70 & 400 \\
\hline & $(58-225)$ & $(75-420)$ & $(65-223)$ & $(195-438)$ \\
\hline \multirow[t]{2}{*}{$\mathrm{FTR}_{\text {Puar }} \%$} & 99.1 & 99.0 & 99.4 & 98.0 \\
\hline & $(99.0-99.1)$ & $(98.8-99.0)$ & $(98.9-99.5)$ & $(97.7 .99 .1)$ \\
\hline
\end{tabular}

Data are expressed as medians and IQR. " $p<0.05$ versus BNP. 
Systemic hemodynamic effects

At baseline, no differences in blood pressure (MAP), heart rate (HR), stroke volume (SV), cardiac output (CO) and total peripheral resistance (TPR) were observed between the experiments (Table 4.2). MAP and HR were not significantly altered by infusion of placebo, the combination of placebo/BQ-788, BNP, or the combination of $B N P / B Q-788$ (Figure 4.1). Furthermore, no differences were observed between interventions. $C O$ did not significantly change either during any of the infusions and there were also no differences between visits. Finally, changes in TPR did not differ between the four visits.

$$
\begin{array}{ll}
\rightarrow-\text { Placebo } & -\square-\mathrm{BNP} \\
\rightarrow-\mathrm{BQ} & -\mathrm{BQ} / \mathrm{BNP}
\end{array}
$$
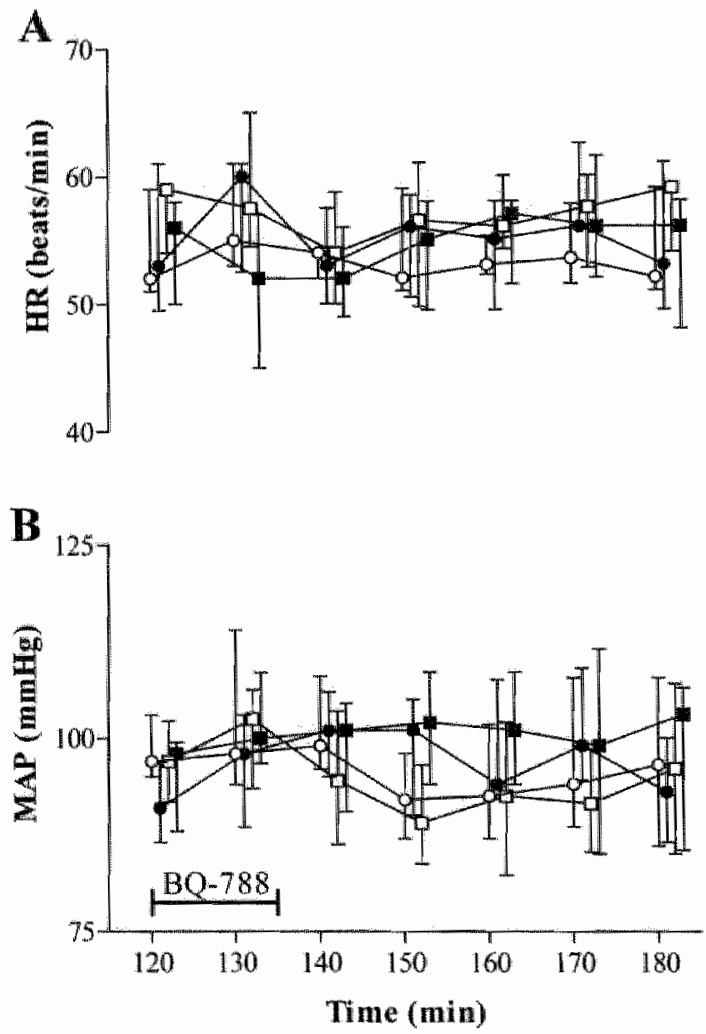

Figure 4.1. Supine heart rate $(H R$, panel $A$ ) and mean arterial blood pressure (MAP, pane B) at baseline and every 10 minutes during 1 hour infusion of placebo or BNP with or without co-infusion of BQ-788 for 15 minutes. Dato are presented as median and interquartile ranges. 


\section{Renal effects}

Baseline GFR was not the same for the four visits $(p=0.022)$. On the days that BQ-788 was administered baseline GFR was lower than before infusion of BNP alone (Table 4.2), but otherwise baseline renal hemodynamic variables did not differ between visits. GFR significantly increased during infusion of BNP, both when given alone or in the presence of BQ-788 (Figure 4.2). Except for a rise in FF after BNP infusion alone, no changes in ERPF and FF were observed during any infusion (Figure 4.2). No differences or changes in RVR and RF were observed between visits.
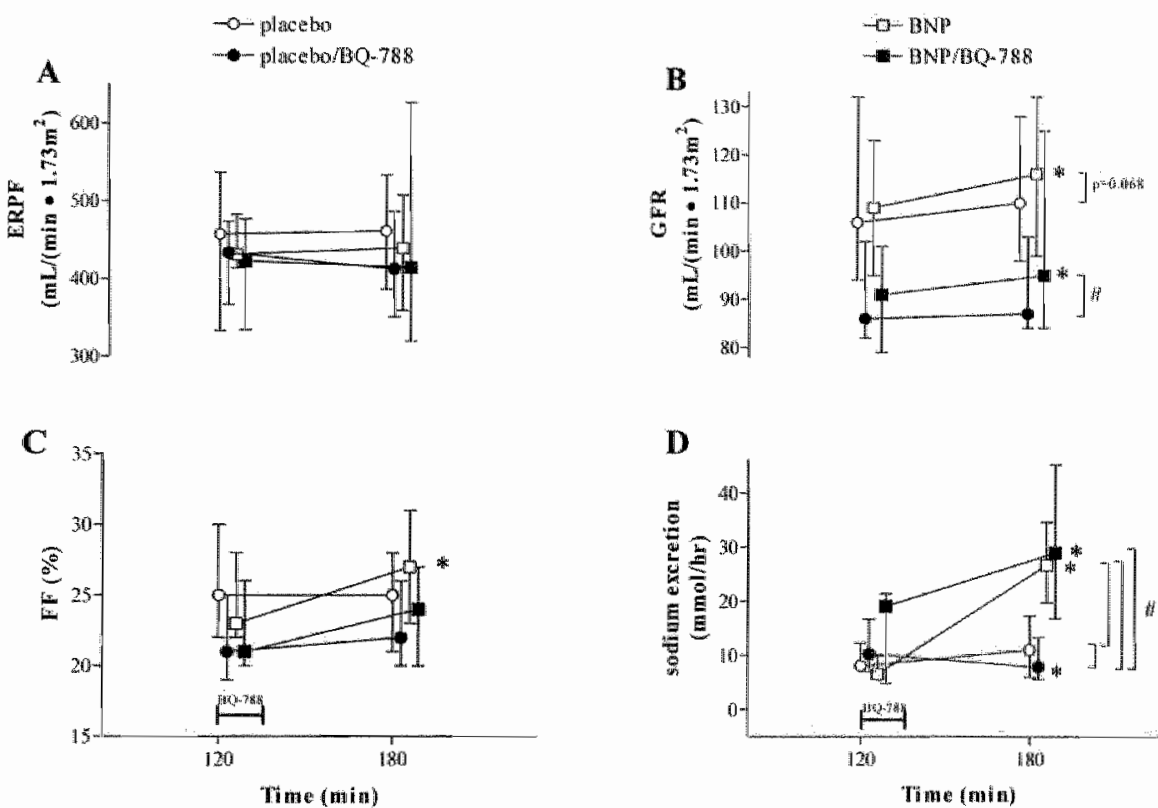

Figure 4.2. Renal hemodynamic responses of renal plasma flow (ERPF, panel A), glomerular filtration rate (GFR, Panel B), filtration fraction (FF, Panel C), and sodium excretion (Na+, panel D) to intravenous infusion of placebo or BNP infusion with or without co-infusion of $\mathrm{BQ}-788$. Data are expressed as percentage change and presented as median and $I Q R^{*} p<0.05$ versus baseline. " $p<0.05$ between interventions.

At baseline, $U_{N a} V$ and urinary volume were comparable for all visits (Table 4.2). BNP with or without co-infusion of BQ-788 induced a significant natriuresis. Urinary sodium excretion in the one-hour urine collection remained unchanged during the placebo experiment, but fell significantly during placebo/BQ-788 infusion to $7.9(5.6-13.3) \mathrm{mmol}$ 
$(p=0.043 ;$ Figure 4.2) Sodium excretion increased to $29.0(16.8-45.2)$ mmol and to $26.6(19.7-34.6) \mathrm{mmol}$ respectively during BNP with and without $\mathrm{BQ}-788$ (Figure 4.2). Natriuretic responses did not differ when $B N P$ alone was compared to $B N P / B Q-788(p=0.345$; Figure 4.2$)$. The urinary volume of the one-hour urine collection significantly rose to 460 (378-743) $\mathrm{mL}$ after BNP infusion, while it did not increase significantly during the other infusions in spite of the water suppletion during the renal clearance study protocol. However, percent changes in diuresis did not differ between BNP alone and during combination of BNP/BQ-788.

$\mathrm{F} L_{\text {सa }}$ increased significantly from $1048(792-1313) \mathrm{mmol} / \mathrm{hr}$ to 1116 (829-1412) mmol/hr during BNP and from $861(664-1037) \mathrm{mmo} / \mathrm{hr}$ to $905(706-1287) \mathrm{mmol} / \mathrm{hr}$ during co-infusion of $\mathrm{BNP}$ and $\mathrm{BQ}-788$, while placebo with or without $B Q-788$ infusion did not influence $F L_{N o}$.

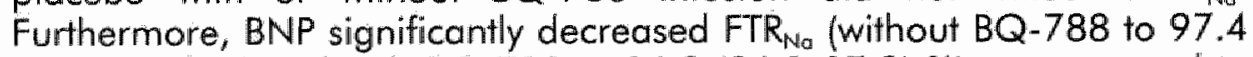
(97.1-98.2) \% and with BQ-788 to 96.8 (96.1-97.9) \%) as compared to placebo $(p=0.019)$, there being no differences between the two experiments with or without co-infusion of $B Q-788$. No difference in $\mathrm{FTR}_{\text {Na }}$ was observed between the combination of placebo/BQ-788 and infusion of placebo alone or between $\mathrm{BNP} / \mathrm{BQ}-788$ and $\mathrm{BNP}$ infusion alone.

\section{Discussion}

The present study was designed to test the hypothesis that the renal effects of BNP (enhanced GFR and natriuresis) are mediated by ET-B receptors. However, while our data indicate that selective ET-B receptor antagonism by itself decreases renal sodium excretion, we found no evidence for an effect of ET-B receptors on BNP-induced natriuresis or diuresis. Moreover, the rise in glomerular filtration rate as observed during administration of BNP is not influenced by ET-B receptor blockade.

The rise in plasma ET-1 levels which we observed after BNP infusion probably reflects a spontaneous phenomenon related to our study design or to diurnal changes, since this increase is also observed after placebo infusion. Selective ET-B receptor blockade appeared to prevent this rise in plasma ET-1, which is surprising because one would expect an even greater rise because the peptide is normally cleared by the ET-B receptor." Although we cannot readily explain these observations, if is unlikely that changes in plasma ET-1 are relevant for the present results.

Strachan et al. demonstrated substantial systemic vasoconstriction, associated with a reduction in $H R$ and cardiac index, but no change in $M A P$, in response to administration of the selective ET-B receptor antagonist $\mathrm{BQ}-788$ in healthy men. ${ }^{7}$ These effects were most prominent with the highest dose of BQ-788 (300 $\mathrm{nmol} / \mathrm{min}$ ), but were not clearly 
seen at lower doses. In the present study we employed a low dose of the anfagonist and did not observe any significant changes in systemic hemodynamics. Therefore, it is unlikely that renal effects of $B Q-788$ in this study are related to systemic vasoconstriction.

Experiments in anaesthetised rats have shown that low doses of intravenous ET- 1 cause natriuresis due to reduced sodium transport in the proximal and distal nephron segments and that higher doses result in sodium retention due to glomerular vasoconstriction. ${ }^{10}$ Data obtained with ET-A and ET-B specific antagonists in anaesthetized dogs indicate that the ET-A receptor predominantly accounts for renal vasoconstriction, while the ET-B receptor is largely responsible for diuresis and natriuresis. "The results of our human study are in line with these animal experiments, since low-dose ET-B blockade decreased urinary sodium excretion, without changing ERPF, GFR, and FF. We could not demonstrate a BQ-788 induced increase in fractional tubular sodium reabsorption in man, but for this to become apparent, one probably needs larger groups of subjects.

Previous investigations have demonstrated that BNP is able to induce a dose-dependent vasodilatation through activation of the natriuretic peptide receptor $A$ (NPR-A), with an associated increase in CGMP, as well as by production of nitric oxide (NO) ${ }^{5}$ In line with our previous work, the present data confirmed that BNP infusion enhanced the release of plasma and urinary CGMP, urinary sodium excretion, and urine volume along with a significant increase in GFR, FF and filtered load of sodium. Furthermore, BNP infusion did not change systemic hemodynamics either. Therefore, it is fair to conclude that the dose of BNP, which we used, was able to activate its receptors and enhance the release of its second messenger CGMP, but low enough to keep systemic hemodynamics unaffected.

BNP could increase GFR in three possible ways, namely by preglomerular vasodilatation, by post-glomerular vasoconstriction, and/or by changing filtration surface area. The first possibility, pre-glomerular vasodilatation, is not very likely to have occurred since we did not notice any changes in ERPF. Of course, we cannot exclude that BNP augments filtration surface area, but presently there are no good tools to investigate this in an unbiased way. For the time being, therefore, we consider post-glomerular vasoconstriction the most likely mechanism of the BNP-induced rise in GFR.

None of the effects of BNP were modified by concurrent administration of the ET-B receptor antagonist. Nevertheless, an obvious limitation in this study is that we could not assess the degree of ET-B receptor blockade. Indeed, infusion of ET-1, to demonstrate a shift in de dose-response curve, would not only stimulate ET-B but also unoccupied ET-A receptors, making unambiguous conclusions impossible. However, the fact that ET$B$ receptor blockade was associated with anti-natriuresis suggests that we did achieve adequate blockade." 
Irrespective of the mechanisms, the intrarenal hemodynamic and natriuretic effects of BNP were not affected by the anti-natriurefic action of $B Q-788$. It is possible that the renal effect of BNP overruled ET-B receptor antagonism, but this is unlikely since we used a low dose of BNP. Therefore, we conclude that ET-B receptors are not involved in the BNP-induced stimulation of GFR. 


\section{References}

1. La Villa G, Stefani L, Lazzeri C, Zurli C, Guerra $C T$, Barletta G, Bandinelli $R$, Strazzulla $G$, Franchi $F$. Acute effects of physiological increments of brain natriuretic peptide in humans. Hypertension. 1995:26:628-33.

2. wan der Zander $K$, Houben AJHM, Kroon AA, Werema TKA, Fuss-Lejeune MJMJ, Koster D, de Leeuw PW. Hypertension 2003;41:119-123.

3. De Feo ML, La Villa G, Lazzeri C, Tasti-Guerra C, Becorpi A, Pupilli C, Mannelli M. Urinary endothelin-1 excretion is enhanced by low-dose infusion of brain natriuretic peptide in normal humans. Hypertension. 1997;29:70-74.

4. Nitta K, Naruse $M$, Sanaka T, Tsuchiya K, Naruse K, Zeng ZP, Demura H, Sugina $N$. Natriuretic and diuretic effects of endathelin in isolated perfused rat kidney. Endocrinol Jpn. 1989;36:887-990.

5. van der Zander K, Houben AJ, Kroon AA, De Mey JG, Smits PA, de Leeuw PW. Nitric axide and potossium channels are inwolved in brain natriuretic peptide induced vasodilatation in man. $\mathrm{J}$ Hypertens. 2002;20:493-499.

6. World Medical Association Declaration of Helsinki. Recommendations guiding physicians in biomedical research involving human subjects. Cardiovasc Res. $1997 ; 35: 2-3$.

7. Strachan FE, Spratt JC, Wilkinson IB, Johnston NR, Gray GA, Webb DJ. Systemic blockade of the endothelin-B receptor increases peripheral vascular resistance in healthy men. Hypertension. 1999;33:581-585.

8. Cole $B R$, Giangiacomo J, Ingelfinger $J R$, Robson $A M$. Measurement of renal function without urine collection. A critical evaluation of the constant-infusion technic for determination of inulin and para-aminohippurate. N Engl J Med. 1972;287:1109. 1114.

9. Fukuroda T, Fujikawa $T$, Ozaki S, Ishikawa K, Yano M, Nishikibe M. Clearance of circulating endothelin- 7 by ETB receptors in rats. Biochem Biophys Res Commun. 1994:199:1461-1465.

10. Harris. PJ, Zhuo J, Mendelsohn FA, Skinner SL. Haemodynamic and renal tubular effects of low doses of endathelin in anaesthetized rats. J Physiol. 1991;433:25-39.

11. Clavell AL, Stingo AJ, Margulies KB, Brandt RR, Burnett JC, Jr. Role of endothelin receptor subtypes in the in vivo regulation of renal function. Am I Physiol. 1995;268:F455-F460. 



\section{Chapter}

\section{Effects of Brain Natriuretic Peptide on forearm vasculature: comparison with Atrial Natriuretic Peptide}




\section{Abstract}

The aim of the present study was to determine the wasoactive effects of brain natriuretic peptide (BNP) as compared to those of atrial natriuretic peptide (ANP) in normal man.

Ten healthy male subjects (median age 21 (20-23) year) were studied twice. In the first study equimolar doses $(1,3$, and $10 \mathrm{pmol} / \mathrm{dl} / \mathrm{min}$ ) of both BNP and ANP (in random orcler and double blind) were infused into the brachial artery of the non-dominant arm with a 1-hour washout period in between. In the second study two BNP $(n=5)$ or ANP $(n=5)$ dose-response curves were performed in order to assess the repeatability of the BNP/AMP infusions. To this end, BNP and ANP were infused in the same equimolar doses as in the first protocol. Forearm blood flow (FBF) was determined by venous occlusion plethysmography before and during infusions.

BNP increased the FBF ratio (infused/contrallateral arm) by $6 \%, 17 \%$, and $48 \%$, respectively $(\mathrm{p} 0.05)$, while ANP increased the FBF ratio by $4 \%, 58 \%$, and $133 \%$ (p0.001). The slopes of the BNP dose-response curves differed significantly from those of the ANP curves (18.1 versus $43.2 ; p=0.022)$. No differences were observed between the repeated dose-response curves of either BNP or ANP.

The present data demonstrate that BNP induces a dose-dependent vasodilatation in man. On a molar basis, however, this vasadilatation is significantly less than the vasodilatition induced by ANP. These differences may be related to differences in natriuretic-pepticlereceptor affinity. Furthermore, our data show that the vasoactive effects of both BNP and ANP are repeattable in time. 


\section{Introduction}

Atrial Natriuretic Peptide (ANP) and Brain Natriuretic Peptide (BNP), two members of the family of natriuretic peptides, stimulate sodium excretion by the kidney. BNP is mainly produced in the ventricles of the heart", while ANP is secreted from the atria. However, the mechanisms controlling the release of ANP and BNP may be different for the two peptides. This is corroborated by the finding that intravascular saline loading acutely increases the plasma concentrations of ANP without any effect on plasma BNP concentrations. ${ }^{2}$ On the other hand, increased BNP levels are associated with left ventricular hypertrophy (LVH), and reduced cardiac output. ${ }^{3}$ Hence, BNP may be an marker for LVH or left ventricular dysfunction. ${ }^{4}$ It may be, therefore, that BNP levels more reflect long-term intravascular volume status rather then momentary volume changes.

ANP and BNP not only stimulate natriuresis and diuresis, but also cause vascular relaxation. Whille the renal effects of these two peptides when given in equimolar doses seem to be comparable ${ }^{5-7}$, little is known about their relative potencies at the level of the vascular wall. In fact, the hemodynamic effects of BNP are somewhat contradicting. For instance, in chronic heart failure systemic infusion of BNP results in a fall in blood pressure, systemic vascular resistance, and pulmonary capillary wedge pressure. ${ }^{6}$ On the other hand, studies in both hypertensive patients and healthy subjects reveal no effects of BNP on blood pressure, cardiac output or systemic vascular resistance. 5,8 This difference in results could be related, however, to the BNP levels which were reached.

All previously described effects of BNP and ANP have been derived mainly from animal and human experiments using systemic infusions, although local vascular effects of ANP have been reported as well, the direct vascular effects of BNP have been studied in less detail. In vitro studies suggest that BNP exerts its biological effects through the same pathway as ANP does, i.e. the natriuretic peptide receptor A (NPR-A). However, the affinity of BNP for this receptor is less than that of ANP. $\%$ Because of this difference in affinity, we suspected that ANP will cause a greater degree of vasodilatation than BNP when given in equimalar doses in man. The aim of the present study was, therefore, to compare the local vascular effects of BNP to those of ANP in healthy men. In addition, we wanted to determine the repeatability of the effects of BNP and ANP. 


\section{Subjects and methods}

\section{Subjects}

Experiments were performed in 10 healthy male volunteers, with a median age of 21 (interc. range 20-23) years. One week prior to the measurements, subjects followed an ad libitum salt diet, which resulted in a median $24 \mathrm{~h}$ urinary sodium excretion of about $140 \mathrm{mmol}$. They were asked to refrain from smoking and coffeine or alcohol containing beverages for at least 12 hours before the experiments, which started at 8 a.m. after an overnight fast.

Furthermore, none of the subjects had used any medication (including non-steroidal anti-inflammatory drugs) in the two weeks prior to the measurements.

The study was approved by the Medical-Ethics Committee of the Maastricht University Hospital, and all participants gave written informed consent. The investigations conform with the principles outlined in the Declaration of Helsinki."

\section{Experimental design}

All volunteers were studied twice with a 2 -week interval. The order of the experiments was randomised. Subjects were studied in supine position in a quite, temperature-controlled room (mean temp. $24.1 \pm 0.2^{\circ} \mathrm{C}$ ). A 20gauge catheter was inserted into the brachial artery of the non-dominant arm (under local anaesthesia, 1\% lidocaine): for infusion of drugs and monitoring of blood pressure. Forearm volume was measured by water displacement; drug infusion rates were normalised to $100 \mathrm{ml}$ forearm tissue.

In the first study, forearm vascular reactivity to repeated dose-response curves of ANP $(N=5)$ or BNP $(N=5)$ was studied. In the second study, forearm vascular reactivity to infusion of equimolar doses of both ANP and BNP was studied. These infusions were performed in random order and in a double blind fashion. The two studies were performed according to a similar experimental design.

Equimalar peptide doses of 1,3 , and $10 \mathrm{pmol} / 100 \mathrm{ml}$ forearm $/ \mathrm{min}$ were used in both studies, which was based on data obtained in pilot experiments as well as on data from literature. ${ }^{12}$ Each dose was infused for 5 minutes. Forearm blood flow (FBF) was determined simultaneously in both arms using ECG-triggered venous occlusion plethysmography (ID-Plethysmograph, University of Maastricht, The Netherlands), as described in detail previously. ${ }^{13}$ Blood pressure was measured intraarterially using a Hewlett Packard $78205 \mathrm{C}$ monitor. Heart rate was derived from the ECG.

Basal measurements of blood pressure, heart rate, and FBF were obtained 15 minutes after insertion of the arterial catheter. Following another 15 minutes the first dose-response curve was determined, with 
FBF being recorded continuously from 2 minutes before untill the end of infusion of BNP/ANP. The mean value of the last minute of each dose 10 , 1,3 , and $10 \mathrm{pmol} / \mathrm{dl} / \mathrm{min}$ ) was used for the analyses. Before the next infusion of BNP/ANP, there was a 1 -hour recovery period in order to allow forearm blood flow (FBF) to return to baseline values.

All signals were stored on the hard disk of a personal computer by means of a custom-built data acquisition system.

\section{Drugs}

All solutions were freshly prepared in $5 \%$ glucose immediately before infusion. ANP and BNP were obtained from Clinalfa (Ethifarma Nederland BV, The Netherlands).

\section{Statistics and calculations}

For each measurement of FBF the ratio between the infused arm and the contralateral arm was calculated. This ratio corrects for all systemic factors that affect the regulation of blood flow in both arrns (e.g. changes in blood pressure, level of arousal, hormonal changes, etc.), and is stable during the day. ${ }^{14}$ Furthermore, it ensures that the direct effects of locally infused substances on forearm blood flow can be assessed. ${ }^{15}$ For each separate dose of drug the percentage change in FBF ratio (rellative to pre-infusion values) was calculated. This calculated value is less influenced by possible changes in FBF. ${ }^{15}$

Besides calculation of ANP/BNP dose-response curves for each individual, also individual concentration-response curves were calculated by correcting the dose for FBF at the time of infusion. ${ }^{16}$ The slopes of both the dose-response and the concentration-response curves were calculated individually by linear regression of the percentage change in FBF ratio during the three doses of ANP/BNP. These slopes summarise each individual response to the three doses in one number. Statistically, this calculation will avoid the problem of repeated measures between the three doses.

Since the distribution of the FBF data within the group was not normall, data are presented as median values with interquartile ranges. Friedman's test (non-parametric two-way ANOVA) was used for analysis of multiple related samples (within one visit) and Wilcoxon paired sign test for paired analysis (between visits and within one visit). When appropriate, the Bonferroni correction was used for multiple comparisons. P values below 0.05 were considered statistically significant.

To examine the repeatability of the effects of both hormones, the BlandAltman method was applied." 


\section{Results}

The baseline clinical characteristics of the ten male study participants are summarised in Table 5.1. Median urinary sodium output in the 24 hours prior to the first study was $139(11)-172) \mathrm{mmol}$, and prior to the second study $143(91-196) \mathrm{mmol}$, indicating that salt intake of the subjects was not significantly different between the two experiments.

Table 5.1 Characteristerics of the ten study participants

\begin{tabular}{lc}
\hline Characteristic & Value \\
\hline Age, $\mathrm{yr}$ & $21(20-23)$ \\
Weight, $\mathrm{kg}$ & $79(7)-83)$ \\
Length, $\mathrm{m}$ & $1.83(1.80-1.85)$ \\
Body Mass Index, $\mathrm{kg} / \mathrm{m}^{2}$ & $23.6(21.3-24.4)$ \\
Heart Rate, beats per $\min$ & $55(50-57)$ \\
Mean arterial pressure, $\mathrm{mmH} H$ & $85(77-90)$ \\
\hline
\end{tabular}

"Values are presented as median and interquartile range

\section{Blood pressure and heart rate}

MAP and HR did not change during any of the studies (Table 5.2), indicating that the local infusions of BNP or ANP had no systemic hemodynamic effects.

Table 5.2 Heart rate and mean arterial pressure of the subjects at the beginning and end of the two studies

\begin{tabular}{|c|c|c|c|c|}
\hline & \multicolumn{2}{|c|}{ Heart Rale (beats per min) } & \multicolumn{2}{|c|}{ Mean Arterial Pressure (mm Hg) } \\
\hline & Start & End & Start & End \\
\hline Study 1 & $54(51.57)$ & $56(50-60)$ & $82(72.89)$ & $85(74.93)$ \\
\hline Study 2 & $55(49-58)$ & $53(50-59)$ & $84(75-93)$ & $84(80.94)$ \\
\hline
\end{tabular}

Bload pressure was measured intra-arterially. Values are presented as median and interquartile range.

\section{Study 1 : Repeatability of the effects of BNP/ANP}

The median slopes of the two dose- or concentration-response curves, were comparable both for BNP and for ANP $(p>0.05)$. Using the BlandAltman approach, the mean difference in individual slopes of repeated dose-response curves for BNP is $5.5(95 \%$ confidence interval (C.I.) 22.6 to 33.7 ) and 0.8 (C.I. -6.5 to 8.2) for ANP. The mean difference in maximum percentage change in FBF of repeated infusions is $16.0 \%$ (C.I. -77.0 to 109.0) for BNP and $-6.9 \%$ (C.I. - 19.5-5.6) for ANP. 
Study 2: Comparison of the effects of BNP and ANP on forearm blood flow

Since there was no evidence for a time-treatment interaction, the data from the randomised infusions were pooled for the analysis.

The three doses of BNP increased FBF ratio by $6 \%(-4-23), 17 \%(-3-33)$, and $48 \%(7-87)$, respectively, relative to baseline $(p<.05$; Figure 5.1$)$. The percentage change in baseline FBF ratio for ANP was $4 \%(-5-19)$, $58 \%(20-93)$, and $133 \%(54-173)$, respectively $(p<0.001$; Figure 5.1$)$. In Table 5.3 the absolute flow (FBF) values and FBF ratio at baseline and after each dose of BNP/ANP are summarised.

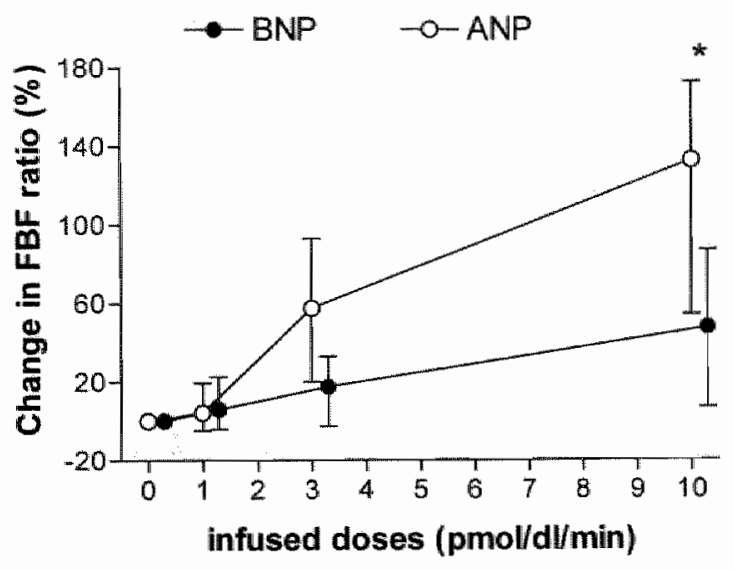

Figure 5.1 Vasoreactivity of forearm (muscle) vasculature to local BNP and ANP infusions (i.a.) (expressed as percent change in FBF-ratio (infused/ contralaterall arm)). Data are presented as median and interquartille range. Both BNP and ANP caused significant dilatation $(\mathrm{p}<05)$. * $P<05$ BNP versus ANP.

Post hoc analysis of the three doses separately revealed that at the highest dose $(10 \mathrm{pmol} / \mathrm{dl} / \mathrm{min}$ ) the effects of BNP and ANP were significantly different $(p=0.022$; Figure 5.1$)$. The median slope of the regression line through the individual dose-response curves was 18.1 $(4.7-28.3)$ for BNP and $43.2(19.8-60.8)$ for ANP $(p=0.022$; Figure 5.2A). The median slope of the regression line through the concentration-response curves was $7.2(0.3-16.8)$ for BNP and 25.5 $(12.9-40.8)$ for ANP $(p=0.017$; Figure 5.2B). 
Table 5.3 Absolute FBF values and FBF ratio after each infused dose

\begin{tabular}{|c|c|c|c|c|}
\hline & $\begin{array}{c}\text { Dose } \\
\text { (pmol/d//min) }\end{array}$ & $\begin{array}{c}\text { FBF Infused arm } \\
(\mathrm{ml} / \mathrm{dl} / \mathrm{min})\end{array}$ & $\begin{array}{l}\text { FBF Contralateral arm } \\
(\mathrm{ml} / \mathrm{d} / \mathrm{min})\end{array}$ & $\begin{array}{c}\text { FBF-Ratio ( }=\text { inf./d) } \\
(\mathrm{m} / / \mathrm{dl} / \mathrm{min})\end{array}$ \\
\hline \multirow[t]{4}{*}{$\mathrm{BNP}$} & baseline & $2.7(2.5-3.3)$ & $2.6(2.2-3.5)$ & $0.96(0.82-1.33)$ \\
\hline & 1 & $3.0(2.7-3.3)^{b}$ & $2.8(2.3-3.7)$ & $1.05(0.83-1.28)$ \\
\hline & 3 & $3.2(2.7-3.9)$ & $2.9(2.0 .4 .2)$ & $1.20(0.83-1.33)^{8}$ \\
\hline & 10 & $4.2(3.8-5.0)^{c}$ & $2.9(2.3-4.6)$ & $1.43(0.86-1.86)^{b . d}$ \\
\hline \multirow[t]{4}{*}{ ANP } & boseline & $2.8(2.2-3.2)$ & $2.7(2.3-3.6)$ & $0.86(0.82-1.17)$ \\
\hline & 1 & $3.0(2.4-3.7)$ & $3.1(2.3-3.7)$ & $1.08(0.83-1.22)$ \\
\hline & 3 & $5.0(3.2-6.0)^{c}$ & $3.5(2.5-3.9)$ & $1.49[1.11-1.95)^{6}$ \\
\hline & 10 & $6.7(5.1-8.4)^{c}$ & $3.3(2.5-4.2)^{c}$ & $2.12(1.85-2.40)^{c}$ \\
\hline
\end{tabular}
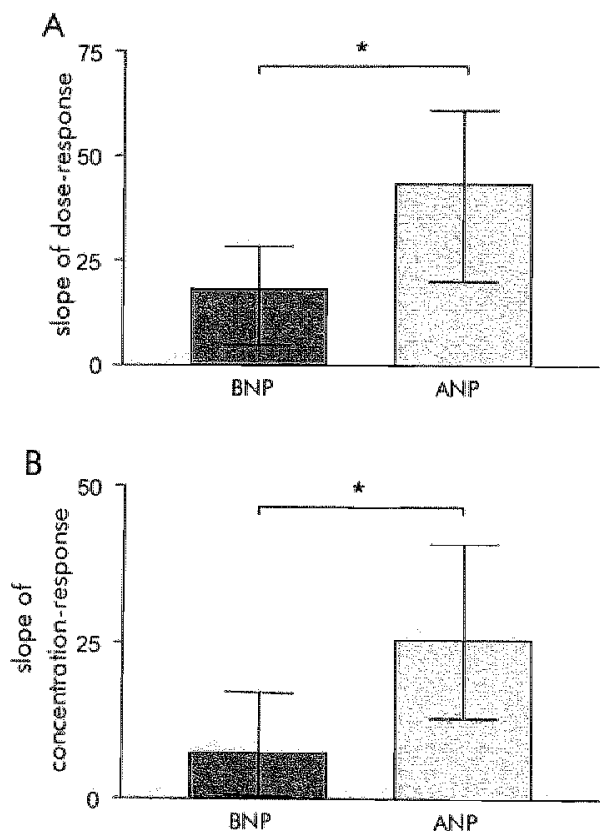

Figure 5.2 Slope of the regression line through the individual dose-response curves (A) and the individual concentration-response curves $(B)$ during BNP and ANP infusions. Data are presented as median and interquartile rangle ${ }^{*} P<0.05$ BNP versus ANP.

\section{Discussion}

The present data demonstrate that local BNP infusion in man induces a dose-dependent vasodilatation, which is significantly less than that induced by equimolar doses of ANP. Since the vasoactive effects of both 
BNP and ANP are repeatable in time, the difference between both peptides seems to be genuine and not due to some aspecific effect. Although we did not measure cardiac output, the design of the study and the use of FBF-ratio rather then absolute FBF values, make it extremely unlikely that the difference in effect between BNP and ANP can be explained by differential systemic effects of the two peptides. In addition, no changes in blood pressure and heart rate were apparent, which also argues against systemic effects of the agents.

Previous studies have shown that human BNP is able to relax human artery and vein tissue. ${ }^{18}$ In healthy human beings and patients with chronic heart failure Nakamura ef al. ${ }^{19}$, using much higher doses than we did, also found a peripheral vasodilating effect of BNP.

At present, three different natriuretic peptide receptors (NPR) have been described: NPR-A, NPR-B, and NPR-C.,20 The NPR-A and NPR-B are transmembrane guanylate cyclases, but the NPR-C is a short transmembrane protein which functions through intermediate G-proteins to inhibit adenylate cyclase and stimulate the phosphoinositol pathway. The latter has been called the clearance receptor, but binding to this receptor results in biological activity as well. ${ }^{9.20,21}$ Both BNP and ANP are thought to act through the NPR-A. Activation of this receptor generates cGMP, which as second messenger activates $\mathrm{Ca}^{2+}$-activated and ATP. sensitive $\mathrm{K}^{+}$-channels, finally resulting in vasorelaxation. ${ }^{22,23}$

The fact that BNP-induced vasodilatation is significantly less than that induced by equimolar doses of ANP could be explained by a difference in receptor-affinity. Cell culture experiments (human tissue cells) have shown that the affinity of BNP for NPR-A is 4-70 times less compared to ANP. 9.10 Consequently, BNP is 10-fold less potent than ANP to stimulate cGMP production via the NPR-A.?

There is, however, a body of evidence in the literature that does not support the concept of lesser affinity of the NPR-A for BNP. For instance, Nakamura et al. ${ }^{19}$ found no difference in forearm vasorelaxation between BNP and ANP in heart failure patients, which they explained by a downregulation of the NPR-A in these patients. However, when both ANP and BNP act via the same receptor, such a downregulation would effect the BNP-induced dilatation in a similar proportional manner. Moreover, Protter et al. ${ }^{18}$ showed that human BNP and ANP are equipotent in relaxing isolated preconstricted human arteries. Also in cultured endothelial cells BNP and ANP show a similar dissociation constant and maximal binding capacity for the NPR-A ${ }^{24}$, and both peptides are equipotent in stimulation of endothelial cGMP production. ${ }^{25}$ BNP even induces a 20-fold greater release of CNP by endothelial cells than ANP. ${ }^{26}$ The latter effect was in case of ANP completely and in case of BNP partly CGMP-mediated. Finally, Moritoki et al. ${ }^{27}$ demonstrated in young ( 4 weeks old) animals that ANP-induced vasodilatation is partly mediated via nitric. Hence, these findings suggest the possibility that BNP 
and ANP act partly through different mechanisms, as a result of which the dilatory effect of BNP may be less than that of ANP.

An alternative explanation may be that BNP, except for inducing vasodilation, also stimulates a vasoconstrictor mechanism. Although there are no data availlable to support such a hypothesis, it is well known that ANP can act as a vasoconstrictor. In previous studies we found that low doses of ANP into humans resulted in vasoconstriction of the microcirculation, most likely on the venular side. ${ }^{28} \mathrm{~A}$ comparable observation has been made in renal siudies. ANP dilates preglomerular (afferent) arterioles and constricts postglomerular (efferent) arterioles, thus causing an increased hydraulic pressure in the gllomerular capillaries. ${ }^{29}$ If BNP also has a dual action on the vasculature, the net effect of this peptide will depend on the balance between vasodilating and vasoconstrictor forces. Any difference in efficiency between BNP and ANP could thus depend on differences in this balance.

Plasma levels of BNP are lower than those of ANP in normal human subjects. In several disease states such as chronic heart failure $(\mathrm{CHF})^{30}$ and hypertension ${ }^{31,32}$, in particular when LVH is present, levels of both peptides are elevated. Moreover, BNP levels frequently surpass plasma levels of ANP in severe CHF. ${ }^{7}$ Thus, in view of our findings, it may be that BNP must increase to a greater extent than ANP in order to induce effective vasodilation, and maintain circulatory homeostasis.

In conclusion, our data demonstrate that both BNP and ANP induce vasodilatation of the forearm vasculature of healthy men. However, the effect of BNP is less potent in comparison with ANP. The difference in effect may be related to a difference in affinity for the natriuretic-peptidereceptor-A, or to a different balance in vasodilator and vasoconstrictor effects. Further studies are needed to elucidate the mechanisms of action of BNP. 


\section{References}

1. Ogawa $Y$, Nakao $K$, Mulkoyama $M$, ef al. Natriuretic peptides as cardiac hormones in normotensive and spontaneausly hypertensive rats; The ventricle is the major site of synthesis and secretion of brain natriuretic peptide. Circ Res 1991;69:491-500.

2. Lang CC, Choy AMJ, Turner K, Tobin $R$, Coutie $W$ and Struthers AD. The effect of intravenous saline loading on plasma levels of brain natriuretic peptide in man. $J$ Hypertens 1993; 11:737.741.

3. Nishikimi T, Yoshihara F, Morimoto $A$, ef al. Rellationship between left ventricular geometry and natriuretic peptide levels in essential hypentension. Hypertension 1996; 28: 22-30.

4. Takeda $T$ and Kohno $M$. Brain natriuretic peptide in hypertension. Hypertens Res 1995; 18: 259-266.

5. Holmes SJ, Espiner EA, Richards AM and Yandle TG. Renal, endocrine, and hemodynamic effects of human brain natriuretic peptide in nomal man. J Clin Endocrinol Metab 1993; 76: 91.96.

6. Yoshimura $M$, Yasue $H_{\text {, Morita }} E_{\text {s }}$ et al. Hemodynamic, renall, and hormonal responses to brain natriuretic peptide infusion in patients with congestive heart failure. Circulation 1991; 84: 1581-1588.

7. McGregor A, Richards M, Espiner E, Yandle T and Ikram H. Brain natriuretic peptide administered to man: actions and metabolism. I Clin Endocrinol Metab 1990; 70 : $1103-1107$.

8. Lazzeri $C$, Franchi F, Porciani $C_{f}$ ef al. Systemic hemodynamics and renal function during brain natriurefic peptide infusion in patients with essential hypentension. Am $J$ Hypertens 1995; 8: 799-807.

9. Koller KJ and Goeddel DV. Molecular biology of the natriuretic peptides and their receptors. Circulation 1992; 86: $1081-1088$.

10. Benret BD, Bennet GL, Vitangcol RV, Jewett JRS, Burnier J and Henzel W. Extracellular damain-lgG infusion proteins for thine human natriuretic peptide receptors. I Biol Chem 1991; 266:23060-23067.

11. World Medical Association Declaration of Helsinki. Recommendations guiding physicians in biomedical research involving human subjects. Cardiovasc Res 1997; 35: 2-3.

12. Branten $A J$, Smits $P$, Janssen $T L$, Wollersheim $H$, Thien $T$. Effect of atrial natriuretic peptide an skin microcirculation versus skeletal muscle blood flow. 』Cardiovasc Pharmacol 1996;27: 303-306.

13. Houben AJHM, Schaper NC, de Haan CHA, ef al. Local 24-h hyperglycaemia does not affect endothelium-dependent or -independent wasoreactivity in humans. Am J Physiol 1996; 270: $\mathrm{H} 2014-\mathrm{H} 2020$.

14. Houben AJHM, Slaaf DW, Huvers FC, de Leeuw PW, Nieuwenhuijzen Kruseman AC and Schaper NC. Diurnal variations in total forearm and skin microcirculatory blood flow in mon. Scan J Clin Lab Invest 1994; $54: 161-169$. 
15. Beniamin N, Calver A, Collier J, Robinson B, Vallance P and Webb D. Measuring forearm blood flow and interpreting the responses to drugs and mediators. Hypertension 1995; 25: 918-923.

16. Bruning TA, Kemme M, Chang PC. Muizert $Y$ and van Zwietten PA. Calculation of plasma concentrations of intra-arterially infused compounds in forearm plethysmography. Cordiovasc Res $1998 ; 37: 210-215$.

17. Bland $M$ M and Altman DG. Statistical methads for assessing agreement between two methods of clinical measurement. Loncet 1986: 307-311.

18. Protter AA, Wallace AM, Ferraris VA and Weishaar RE. Relaxant effect of human

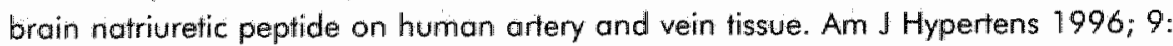
$432-436$.

19. Nakamura $M$, Arakawa $N$, Yoshida $H$, Makita $S$, Ninuma $H$ and Hiramari $K$. Vasodilatory effects of B-type natriuretic peptide are impaired in patients with chronic heart failure. Am Heart J 1998; 135: 414-420.

20. Anand-Srivastava MB. Atrial natriuretic peptide-C receptor and membrane signalling in hypertension. J Hypertens 1997; 15: 815-826.

21. Hempel A, Noll T, Bach $C_{\text {, }}$ ef al. Atrial natriuretic peptide clearance receptor participates in modulating endothelial permeability. Am J Physiol 1998; 275: H1818-1825.

22. Kuba M, Nakaya $Y$, Matsuoka S, Saito K and Kuroda $Y$. Atrial natriuretic factor and isosorbide dinitrate modulate the gating of ATP-sensitive $K+$ channells in cultured vascular smooth muscle cells. Circ Res 1994; 74: 471-476.

23. Price JM and Hellermann A. Inhibition of EGMP mediated relaxation in small rat coronary arteries by black of $\mathrm{Ca} 2+$ activated $\mathrm{K}+$ channels. Life Sci 1997; 61 : 1185- 1192.

24. Gelfand RA, Frank HJL, Levin E and Pedram A. Brain and atrial natriuretic peptides bind to common receptors in brain capillary endothelial cells. Am J Physiol 1991; 261: E183-189.

25. Emari T, Hirata Y, Imai T, Eguchi S, Kanno K and Marumo F. Cellular mechanisms of natriuretic peptides-induced inhibition of endothelin-1 biosynthesis in rat endothelial cells. Endocrinology 1993; 133: 2474-2480.

26. Nazario B, Hu R.M, Pedram A, Prins B and Levin ER. Atrial and brain natriuretic peptides stimulate the production and secretion of C-type natriuretic peptide from bovine aortic endothelial cells. J Clin Invest 1995; 95: 1151-11 157.

27. Moritoki H, Yoshikawa T. Hisayama T and Takevchi S. Possible mechanisms of ageassociated reduction of wascular relaxation caused by atrial natriuretic peptide. Eur J Pharmacol 1992; 210:61-68.

28. Houben AJHM, Krekels MME, Schaper NC, Fuss-Lejeune MIMJ, Rodriguez SA and de Leeuw PW. Microvascular effects of atrial natriurenic peptide (ANP) in man: studies during high and low salt diet. Cardiovasc Res 1998; 39: 442-450.

29. Brenner BM, Ballerman BJ, Gunning ME and Zeidel ML. Diverse biological actions of atrial natriuretic peptide. Physiol Rev 1990; 70:665-695.

30. Mukoyama $M$, Nakao $K$, Hosoda $K$, et al. Brain natriuretic peptide as a novel cardiac hormone in humans. J Clin Invest 1991; 87: 1402-1412. 
31. Lavilla $G$, Vena $S$, Conti A, Franzaroli C, Brat A and Lazzeri C. Plasma lewels of brain natriuretic peptide in heathy subjects and patients with essential hypertension: Response to posture. Clin Sci 1993; 85: $411-416$.

32. Buckley $M$, Sethi D, Markandu $N$, Sagnella $G$, Singer D and MacGregar G. Plasma concentrations and comparisons of brain natriuretic peptide and atrial natriuretic peptide in normal subjects, cardiac transplant recipients and patients with dialysisindependent or dialysis-dependent chronic renal failure. Clin Sci 1992; 82: 127 . 131. 

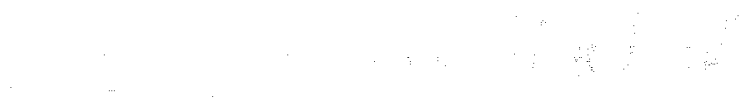

$$
\text { : }
$$




\section{Chapter}

Nitric Oxide and potassium channels are involved in Brain Natriuretic Peptide induced vasodilatation in man

$K$ van der Zander, AJHM Houben, AA Kroon, JGR De Mey, PABM Smits, PW de Leeuw 


\section{Abstract}

Brain notriurefic peptide (BNP) couses vasodilatation but the mechanisms by which this is accomplished are not fully known. The aim of the present siudy was to determine whether besides $K^{4}$ cos -channels, nitric oxide $(N O)$ is involved in BNP-induced vasodilatation.

We studied ten healthy males wice, in random order, at a 2 weeks inferval. Experiments always started with infusion of BNP (8-16-32-64 pmol/d//min) into the brachial antery. On one day this infusion was followed by a second BNP infusion combined with the $\mathrm{K}^{4} \mathrm{Coz}$-channel-blocker Tetra-Ethyl-Ammonium (TEA, $0.1 \mathrm{mg} / \mathrm{dl} / \mathrm{min}$ ) and on the other doy by BNP infusion combined with the NO-synthase inhibitor L-NG-monomethyl arginine (L.NMMA $0.8 \mu \mathrm{mol} / \mathrm{d} / \mathrm{m} / \mathrm{min})$. The latter was then followed by a combined infusion of BNP. L-NMMA and TEA. All infusions were separated by a 1 h-washout period. Farearm blood flow (FBF) was determined by venous occlusion plethysmography.

Mean arterial pressure and heart rate did not change during any of the experiments. BNP alone induced a dose-dependent dilatation, which was silmilar on both days. TEA, LNMMA, and their combination all reduced the BNP-induced dilatation $(p<0.05)$. The combined infusion had a significantly greater effect than TEA alone $(p=0,005)$. BNP infusions were associated with a significant increase in plasma cGMP and C-type natriurefic peptide (CNP) $(p<0.05)$.

BNP induces arterial vasodilatation not only by opening $\mathrm{K}^{+}$ca2+ channels, but alsa via stimulation of NO production. In addition, BNP stimulates net CNP increase. 


\section{Introduction}

A variety of data suggests that atrial natriuretic peptide (ANP) and brain natriuretic peptide (BNP) constitute a dual natriuretic peptide system that responds differently to short- and long-term volume load.,2 Patients with essential hypertension who develop left ventricular hypertrophy or frank heart failure usually have elevated plasma levels of BNP,4, but the significance of this finding is not well understood. Given the recent demonstration that intravenous administration of BNP improves hemodynamic function and clinical status in patients with decompensated congestive heart failure $(\mathrm{CHF})^{5,6}$, it is important, therefore, to further unravel the mechanisms by which this peptide acts. This would not only increase our knowledge about the pathophysiological significance of the hormone but potentially also offer new targets for pharmacotherapeutic modulation.

In vitro studies suggest that BNP exerts its vascular effects through the same pathway as ANP, i.e. the natriuretic peptide receptor A (NPR-A). This guanylate cyclase receptor is located both on endothelia and vascular smooth muscle cells. ${ }^{7,8}$ Activation of this receptor generates CGMP, which as second messenger activates $\mathrm{Ca}^{2+}$-activated and ATPsensitive potassium $\left(K^{+}\right)$-channels, thus promoting vasorelaxation. ${ }^{9,10}$ Furthermore, both BNP and ANP can stimulate CNP production and secretion by endothelial cells. ${ }^{7}$ CNP reacts with its specific guanylate cyclase receptor on the vascular smooth muscle cell, also causing vasodilatation through hyperpolarisation."

Despite an apparent similar pathway of action for both peptides, we and others have shown that in healthy man BNP-induced vasodilatation is significantly less than that induced by equimolar doses of ANP. ${ }^{12,13}$ Such a discrepancy in effect could be related to a difference in affinity for the NPR-A ${ }^{14.15}$, but not all data in the literature are compatible with this explanation. For instance, Nakamura et al. ${ }^{13}$ found that the difference in vasodilatation between BNP and ANP as observed in healthy controls was not present in patients with CHF. This has been explained by a downregulation of receptor (NPR-A) density in these patients. ${ }^{16}$ However, when both ANP and BNP would act through the same receptor such a downregulation should affect BNP-induced dilatation in a similar and proportional manner.

Based on experiments which showed that BNP-induced vasodilatation of pig coronary arteries could be blocked by nitric axide (NO) synthase inhibition ", and the finding of a close relationship between the basal production of $\mathrm{NO}$ in CHF patients and the severity of heart failure as reflected by plasma BNP levels ${ }^{18}$, we hypothesised that BNP acts partly via the NPR-A, and partly via another (endothelium-dependent) 
mechanism involving NO. If is, however, unclear whether this $\mathrm{NO}$ involvement in BNP vasodilatation is NPR-A dependent or not. The aim of the present study was, therefore, to assess to what extent calcium-

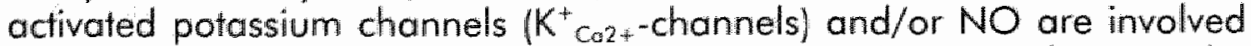
in BNP-induced vasodilatation in man. Studies were carried out in the forearm skeletal muscle vascular bed of healthy subjects.

\section{Methods}

\section{Subjects}

Experiments were performed in 10 healthy male volunteers (median age 20 (range 18-24) years). In the week prior to the measurements, subjects ate a $150 \mathrm{mmol} \mathrm{Na}^{+}$-containing diet to minimize variations in results due to salt intake. In addition, they had to refrain from smoking and drinking caffeine or alcohol containing beverages for at least 12 hours before the experiments, which started at $8 \mathrm{a} . \mathrm{m}$. after an overnight fast. None of the subjects used any medication (including non-steroidal anti-inflammatory drugs) during the two weeks prior to the measurements. The Medical Ethics Committee of the Maastricht University Hospital approved the study, and all participants gave written informed consent. The investigations conformed to the principles outlined in the Declaration of Helsinki. ${ }^{19}$

\section{Experimental design}

All volunteers were studied twice with a 2-week interval and in randomised order. During the experiments, subjects remained supine in a quiet, temperature-controlled room (mean temperature $24.0 \pm 0.2^{\circ} \mathrm{C}$ ). Two catheters were inserted into the non-dominant arm: one 20-gauge catheter into the brachial artery (local anaesthesia, 1\% lidocaine) for infusion of drugs and monitoring of blood pressure, and one into the antecubital vein for blood sampling. Forearm volume was measured by water displacement and drug infusion rates were normalised to $100 \mathrm{ml}$ forearm tissue. Both visits started with an infusion of BNP into the brachial artery followed by a one-hour recovery period to allow forearm blood flow to return to baseline levels (Figure 6.1). On the first experimental day, we then infused BNP again, but this time in combination with the $\mathrm{K}^{+}{ }_{\mathrm{Ca} 2+}$-channel-blocker Tetra-Ethyl-Ammonium chloride (TEA, $0.1 \mathrm{mg} / \mathrm{dl} / \mathrm{min}$ ). On the other experimental day, the second infusion consisted of BNP in combination with the NO-synthase inhibitor L-N $N^{G}$-monomethyl arginine (L-NMMA) in a dose of $0.8 \mu \mathrm{mol} / \mathrm{dl} / \mathrm{min}$. This was then followed by an infusion of BNP in combination with L-NMMA and TEA. All experiments were performed in a similar way. Before infusion and at the end of the highest dose of BNP, 
we drew venous blood samples in tubes containing an EDTA/trasylol mixture for analysis of BNP, C-type natriuretic peptide (CNP), and CGMP levels. Previously published data ${ }^{20}$ as well as pilot experiments indicated that the doses of TEA and L-NMMA employed in this study are the maximum ones that inhibit $\mathrm{K}^{+} \mathrm{ca} 2+$-channels and $\mathrm{NO}$-synthase (NOS) respectively without producing systemic hemodynamic effects.

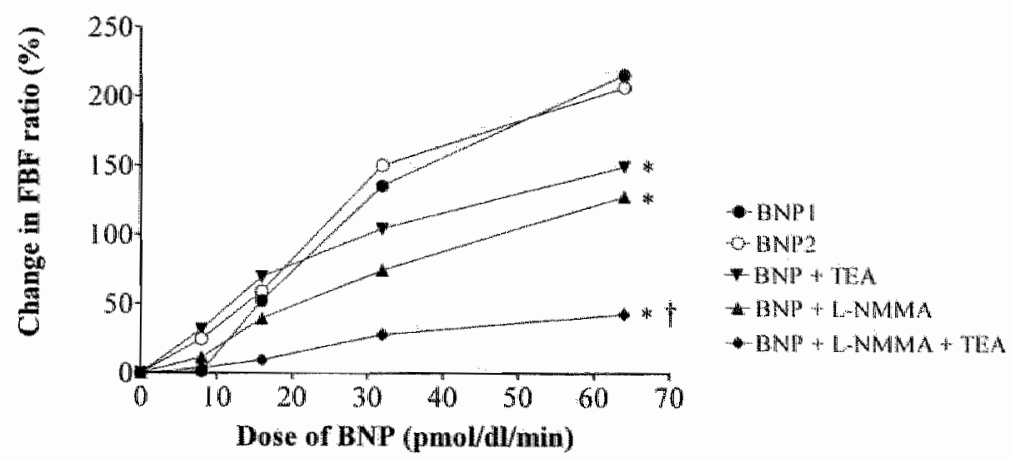

Figure 6.1 Vasoreactivity of forearm (muscle) vasculature to local intra-arterial infusions of BNP with and without inhibitor(s), expressed as percent change in FBF-ratio (infused/ contralateral arm). Data are presented as medians. In all conditions BNP caused significant wasadilatation $(p<0.05)$. For abbreviations: see figure 1. BNP1 and BNP2: first and second BNP infusion respectively.

* $p$ 0.05 versus BNP infusion alone. $+p=0.005$ versus BNP+TEA.

Based on data obtained in a pilot study as well as on data from the literature 12,13 , we infused BNP at doses of $8,16,32$, and $64 \mathrm{pmol} / 100 \mathrm{ml}$ forearm $/ \mathrm{min}$, each dose for 3 minutes. Forearm blood flow $(F B F)$ was determined simultaneously in both arms using ECG-triggered venous occlusion plethysmography as described in detail before." During the measurements a wrist cuff excluded the hand circulation. Blood pressure was measured intra-arterially using a Hewlett Packard $78205 \mathrm{C}$ monitor while heart rate was derived from the ECG.

Basal measurements of blood pressure, heart rate, and FBF were abtained 15 minutes after insertion of the arterial catheter. Following another 15 minutes, the first dose-response curve of BNP was determined, with FBF being recorded continuously from 2 minutes before until the end of the infusion of this peptide. The mean value of the last minute of each dose was used for analysis. Infusion of TEA and/or LNMMA always started 5 minutes before the subsequent BNP doseresponse curve. As described before ${ }^{20,22}$, TEA does not influence baseline FBF. Furthermore, vasodilatation induced by SNP is not inhibited by TEA, indicating that TEA has no inhibitory effect on endothelium-independent vasodilatation. However, because FBF is reduced by L-NMMA, we added sodium nitroprusside (SNP) to the L-NMMA infusion in order to maintain $\mathrm{FBF}$ at its original level ("NO-clamp" technique) before starting the next 
BNP infusion. ${ }^{22,23}$ The dose of co-infused SNP was fitrated individually and held constant during infusion of BNP.

All signals were stored on the hard disk of a personal computer by means of a custom-built data acquisition system (Instrumental Services, Maastricht University, The Netherlands).

\section{Drugs}

On the day of use, TEA was reconstituted from a sterile stock powder (Sigma) diluted in $0.9 \% \mathrm{NaCl}$ to a concentration of $1 \mathrm{mg} / \mathrm{ml}$. Further dilutions were prepared from ampules in $5 \%$ glucose. All solutions were freshly prepared on the day of experiment and stored at $4^{\circ} \mathrm{C}$ until use. BNP and L-NMMA were obtained from Clinalfa (Ethifarma Nederland $B V$, The Netherlands).

\section{Assays}

BNP, CNP and CGMP were measured by means of radioimmunoassay (Peninsula Laboratories Inc. RIK 9086 and RIK 9030, and IBL Hamburg RE 29071, respectively). Before the radioimmunoassay procedure plasma samples of both BNP and CNP were acidified and extracted using a SEP-Pak C18 column (Waters-Millipore). In our hands, the intraand interassay variability are $6.2 \%$ and $10.8 \%$ respectively for BNP, $6.8 \%$ and $11.3 \%$ for CNP and $4.3 \%$ and $8.6 \%$ for CGMP. The antisera for BNP and CNP did not crossreact with the other peptide. All samples from the same individual were assayed in a single run.

\section{Statistics and calculations}

For each measurement of FBF, we calculated the ratio of the infused and the contralateral arm was calculated. This ratio corrects for all systemic factors, which may affect blood flow in both arms and is stable during the day. ${ }^{24}$ Moreover, this ensures that the direct effects of locally infused substances on forearm blood flow can be assessed. ${ }^{25}$ For each separate dose of drug, we determined the individual percentage change in FBF ratio (relative to pre-infusion values). In addition, the areas under the dose-response curves (AUC) were calculated for each individual to avoid the statistical problem of repeated measurements. Net forearm increases of CNP and CGMP were calculated according to the method of Nakamura et al. ${ }^{13,26}$ as the difference between plasma levels of CNP or cGMP at baseline and after the maximum dose of BNP, multiplied by the corresponding change in FBF.

Data are presented as medians with interquartile ranges (IQR). Friedman's test (non-parametric two-way ANOVA) was used for analysis of multiple related samples (within one visit) and Wilcoxon paired sign test for paired analysis (between visits and within one visit). $P$ values below 0.05 denote statistical significance. 


\section{Results}

The median body weight of the participants was 68 (IQR: $67-69$ ) $\mathrm{kg}$ and their height $1.80(1.76-1.82) \mathrm{m}$. This represents a median body mass index (BMI) of $20.5(20.0-21.9) \mathrm{kg} / \mathrm{m}^{2}$.

\section{Blood pressure and heart rate}

Mean arterial pressure (MAP) and heart rate (HR) did not change during any of the studies (Table 6.1), indicating that the local infusions of BNP or inhibitors had no systemic hemodynamic effects. Furthermore, there were no differences in MAP and HR between both visits.

\section{Effect of BNP alone on forearm blood flow}

Baseline FBF values of the infused arm $[2.2(2.0-3.3) \mathrm{ml} / \mathrm{dl} / \mathrm{min}$ at visit 1 and $2.2(1.9-3.1) \mathrm{ml} / \mathrm{dl} / \mathrm{min}$ at visit $2 ; \mathrm{p}=0.208]$, the contralateral arm [2.2 (1.9-2.6) $\mathrm{ml} / \mathrm{dl} / \mathrm{min}$ and $2.1(1.8-2.5) \mathrm{ml} / \mathrm{dl} / \mathrm{min}$, respectively; $\mathrm{p}=0.594]$, and the FBF-ratio $[1.3(0.9-1.6) \mathrm{ml} / \mathrm{dl} / \mathrm{min}$ and $1.2(0.9-1.3)$ $\mathrm{ml} / \mathrm{d} / / \mathrm{min}$, respectively; $\mathrm{p}=0.263$ ] were similar on both days. BNP alone induced a dose-dependent dilatation, which was comparable on the two days (Figure 6.1). The absolute FBF of the infused arm increased to 9.1 $(8.0-11.5) \mathrm{ml} / \mathrm{dl} / \mathrm{min}$ at the highest dose $(\mathrm{p}=0.005)$ at visit 1 , and to 9.4 $(8.1-11.5) \mathrm{m} / \mathrm{d} / \mathrm{d} / \mathrm{min}$ on visit $2(p=0.005)$. Absolute $\mathrm{FBF}$ values of the contralateral arm did not change during BNP infusion.

At the end of infusion, the four doses of BNP had increased the FBF ratio by $216 \%(164-372)$, and $207 \%(169-454)$, respectively, relative to baseline (p<0.001 for both visits; Figure 6.1). The medians of the area under the dose-response curves (AUC) were 7602 (5102-13580) and $7192(5831-17145)$ units respectively.

Table 6.1. Heart Rate and Mean Arterial Pressure of the Subjects at the Beginning and End of the Two Visits

\begin{tabular}{|c|c|c|c|c|}
\hline & \multicolumn{2}{|c|}{ Heart Rate (beats $x$ min } & \multicolumn{2}{|c|}{ Mean Arterial Pressure (mmHg) } \\
\hline & Stont & End & Stait & End \\
\hline Visit 1 & $56(53-61)$ & $59(54-66)$ & $76(70.83)$ & $76(74 \cdots 82)$ \\
\hline Visit 2 & $55(50-62)$ & $60(52-64)$ & $78(73-87)$ & $80(76-82)$ \\
\hline
\end{tabular}

Blood pressure was measured intra-arterially. Values are presented as median and interquartile range.

\section{Effect of inhibitors on BNP-induced vasodilatation}

At the start of all combined infusions the FBF ratios [1.2 (1.0-1.5), 1.2 $(1.0-1.3)$, and $1.1(0.9-1.5)$ respectively] were comparable to baseline values $(p=0.927)$. 
TEA. The absolute FBF value in the infused arm was $2.5(2.3-3.8)$ $\mathrm{ml} / \mathrm{dl} / \mathrm{min}$ and $2.1(1.8-3.0) \mathrm{ml} / \mathrm{dl} / \mathrm{min}$ in the contralateral arm before infusion. In combination with TEA, the four doses of BNP increased the FBF ratio by $32 \%(16-49), 70 \%(30-111), 105 \%(76-152)$, and $150 \%$ $(79.294)$ respectively $(\mathrm{p}<0.001$; Figure 6.1$)$. When the maximal effect of BNP alone is set at $100 \%$, TEA reduced the vasodilatory effect of BNP by $45 \%(20-58)$ at the highest dose of $64 \mathrm{pmol} / \mathrm{dl} / \mathrm{min}(\mathrm{p}=0.005)$. The median AUC for BNP with TEA was significantly smaller than with BNP alone $(p=0.009 ; 6.2)$.

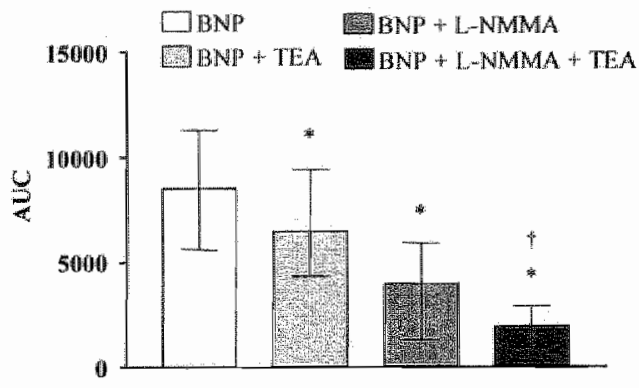

Figure 6.2 Vasoreactivity of forearm (muscle) vasculature to local intra-arterial infusions of BNP with and without inhibitor(s), expressed as the area under the curve (AUC). Data are presented as median and interquartile range. In all conditions BNP caused significant dilatation $(p<0.05)$.

$* p, 0.05$ versus BNP infusion alone. $\dagger p=0.005$ versus BNP+TEA.

L-NMMA. The absolute FBF value in the infused arm was $3.0(2.5-4.1)$ $\mathrm{ml} / \mathrm{dl} / \mathrm{min}$ and $3.0(2.0-3.5) \mathrm{ml} / \mathrm{dl} / \mathrm{min}$ in the contralateral arm before infusion. In combination with L-NMMA, the four doses of BNP increased the FBF ratio by $11 \%(-6-71), 39 \%(2-77), 74 \%(15-121)$, and $128 \%(34-$ 190) respectively $(\mathrm{p}<0.001$; Figure 6.1$)$. This corresponds to a reduction of maximal BNP-induced dilatation by $63 \%(33-82)$ at the highest dose of $64 \mathrm{pmol} / \mathrm{dl} / \mathrm{min}(\mathrm{p}=0.008)$. The median AUC for BNP with L-NMMA was significantly smaller than that of BNP alone $(p=0.038)$, but not different from the AUC for BNP combined with TEA $(p=0.314$; Figure 6.2).

Combination of TEA and L-NMMA. The absolute FBF value in the infused arm was $3.3(2.5-4.2) \mathrm{ml} / \mathrm{dl} / \mathrm{min}$ and $2.8(2.3-3.2) \mathrm{ml} / \mathrm{dl} / \mathrm{min}$ in the contralateral arm before infusion. When combined with both TEA and LNMMA, the four doses of BNP increased the FBF ratio by $3 \%(-26-21)$, $9 \%(-11-36), 28 \%(18-57)$, and $43 \%(29-113)$ respectively $(p<0.001$; Figure 6.1). This corresponds to a reduction of maximal BNP-induced dilatation by $77 \%(69-87)$ at the highest dose of $64 \mathrm{pmol} / \mathrm{dl} / \mathrm{min}$ $(p=0.005)$. The median AUC for BNP in combination with TEA and LNMMA was significantly smaller than that of BNP alone $(p=0.005)$ and that of BNP in combination with TEA $(p=0.005$; Figure 6.2). No significant difference was observed between the effects of BNP in 
combination with L-NMMA and those of BNP in combination with both LNMMA and TEA $(p=0.214)$.

\section{Plasma levels of BNP and CNP, and CGMP}

Forearm intra-arterial infusion of BNP caused the expected increase in venous BNP levels $(p<0.01)$. Baseline plasma BNP levels were 29 (2535) $\mathrm{pg} / \mathrm{ml}$ and $26(24-35) \mathrm{pg} / \mathrm{ml}$ respectively, with no difference between both visits. Plasma BNP levels reached peak values of 3287 (2928-5398) $\mathrm{pg} / \mathrm{ml}, 3813(2862-5441) \mathrm{pg} / \mathrm{ml}, 3910(3379-4925) \mathrm{pg} / \mathrm{ml}, 5066$ $(3933-7377) \mathrm{pg} / \mathrm{ml}$, and $3270(2126-3270) \mathrm{pg} / \mathrm{ml}$, respectively after infusion of BNP alone, BNP with TEA, BNP with L-NMMA, and BNP in combination with both inhibitors. This rise in venous BNP levels was associated with an increase in venous plasma levels of CNP and CGMP.

The plasma CNP level was $3.2(2.1-4.3) \mathrm{pg} / \mathrm{ml}$ at baseline and reached values of $7.1(5.9-9.4) \mathrm{pg} / \mathrm{ml}$, and $7.5(4.8-10.9) \mathrm{pg} / \mathrm{ml}$, respectively after infusion of BNP alone, and BNP in combination with L-NMMA. Although the net calculated CNP increases rose significantly both after infusion of BNP alone and after BNP with L-NMMA, this increase did not differ between both conditions: $12.2(7.0-16.5) \mathrm{fmol} / \mathrm{dl} / \mathrm{min}$ versus 10.4 $(0.7-15.1) \mathrm{fmol} / \mathrm{dl} / \mathrm{min}$.

The plasma CGMP level was $6.4(5.8-8.7) \mathrm{pmol} / \mathrm{ml}$ at baseline and reached peak values of $13.9(12.1-18.6) \mathrm{pmol} / \mathrm{ml}, 23.8(20.0-28.9)$ $\mathrm{pmol} / \mathrm{ml}, 22.2(19.2-30.0) \mathrm{pmol} / \mathrm{ml}$, and $34.9(24.1-41.4) \mathrm{pmol} / \mathrm{ml}$, respectively after infusion of BNP alone, BNP with L-NMMA, BNP with TEA, and BNP in combination with both inhibitors. Net callculated cGMP increase also rose significantly after local infusion of BNP in all conditions (Figure 6.3).

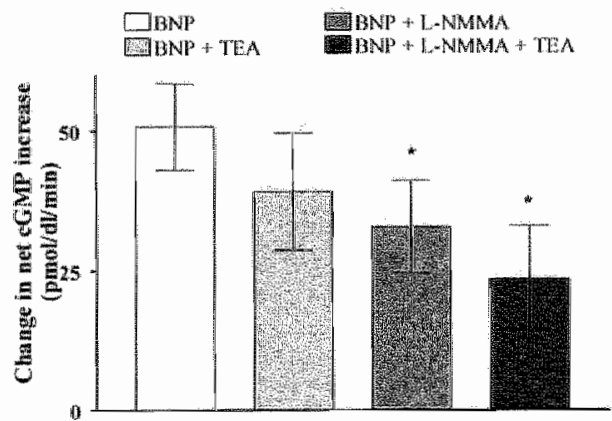

Figure 6.3 Net forearm increase in CGMP induced by local intra-arterial infusions of BNP with and without coinfusion of inhibitor(s). Data are presented as median and inferquartile range. In all conditions net forearm CNP increase rose significantly ( $\mathrm{p}: 0.05) .{ }^{*} \mathrm{p}<0.05$ versus BNP infusion alone.

Coinfusion of BNP and TEA did not change the CGMP net increase as compared to that caused by BNP alone: $47.8(39.2-65.4) \mathrm{pmol} / \mathrm{dl} / \mathrm{min}$ 
versus $37.5(21.9-58.1) \mathrm{pmol} / \mathrm{dl} / \mathrm{min}$. In contrast, BNP was less polent in increasing CGMP with coinfusion of either L-NMMA or L-NMMA and TEA: $33.2(18.3-47.0) \mathrm{pmol} / \mathrm{dl} / \mathrm{min}$ and $15.7(12.2-42.4) \mathrm{pmol} / \mathrm{dl} / \mathrm{min}$ $(p=0.013$ and $p=0.007$ respectively).

\section{Discussion}

The present study shows that local BNP infusion in healthy men induces a dose-dependent vasodilatation, which is significantly attenuated by both potassium-channel inhibition and NO-synthase inhibition. In addition, we found that NO-synthase blockade reduced the BNP-related increase of CGMP, but not of CNP. These findings support the notion that BNP exerts its biological action, at least in part, through stimulation of CGMP and CNP production and opening of potassium channels on the one hand and via NO production on the other. Since no changes in blood pressure and heart rate were apparent, it is unlikely that the effects on forearm blood flow were related to systemic hemodynamic effects of the agents.

At the highest doses, intra-arterial infusion of BNP caused a 100-fold increase in venous plasma BNP levels on both visits. These BNP plasma levels can be considered to be in the pharmacological range, although in heart failure patients it has been shown that plasma BNP levels may be as much as 25-180 times higher as compared to healthy subjects. ${ }^{4}$ In the present study, however, vasodilatation already ensued with a dose of 16 $\mathrm{pmol} / \mathrm{dl} / \mathrm{min}$ during which plasma levels must have been within the pathophysiological range.

BNP is thought to induce vasodilatation by increasing intracellular levels of CGMP, which in turn stimulates $\mathrm{Ca}^{2+}$-activated, and ATP-sensitive potassium channels, thus causing hyperpolarisation. 9,10 TEA antagonises different kinds of potassium channels with varying degrees of potency, but has been shown to selectively block $\mathrm{K}^{+}$ca2--channels in arterial smooth muscle at concentrations below $1 \mathrm{mmol} / / .^{27}$ In the present study, we administered TEA intra-arterially at an infusion rate of 0.1 $\mathrm{mg} / \mathrm{dl} / \mathrm{min}$, which correlates with a calculated local plasma concentration of $0.5 \mathrm{mmol} / \mathrm{I}^{20}$ Since TEA did not abolish the BNP. induced dilatation, but only reduced it by approximately $50 \%$, our data indicate that besides opening of $\mathrm{K}^{+} \mathrm{C}_{02+}$-channels, other dilator pathways must be involved in the vascular effects of BNP. One such pathway may be related to NO, as we found that L-NMMA also significantly reduced BNP-induced vasodilatation. This carroborates data from cellular and animal studies, which also have shown that natriuretic peptides are able to stimulate $\mathrm{NO}$ production. ${ }^{17,28,29}$ It is not clear, however, whether NO production is stimulated via the NPR-A or via an alternative route. In any case, the present study does not provide evidence that $\mathrm{NO}$ release 
induced by BNP would involve stimulation of the NPR-A. Moreover, athers have shown that the natriuretic peptide clearance receptor (NPRC) is more likely to mediate the NO response. ${ }^{29}$

The possibility that besides $\mathbb{N O}$ alternative pathways (e.g. prostaglandins) are involved in BNP-induced vasodilatation cannot be ruled out, since the combination of $\mathrm{NO}$-synthase and $\mathrm{K}^{+} \mathrm{Ca}_{2+}$-channel blockade did not completely prevent the rise in flow. 17 Nevertheless, the fact that the combination of TEA and L-NMMA attenuated BNP-induced vasodilatation even more than TEA alone, does support the hypothesis that both pathways (NPR-A activation and stimulation of $\mathrm{NO}$ ) act in parallel. It may even be that the effect on $\mathrm{NO}$ is quantitatively more important since the combination of TEA and L-NMMA did not have a greater effect than L-NMMA alone.

Our data further show that BNP induces CNP release. CNP is thought to be one of the endothelium derived hyperpolarizing factors (EDHF's), which serve as an autocrine/paracrine endothelium-derived vasoregulatory system. ${ }^{30}$ CNP production in vascular endothelial cells probably plays an important role in the NPR-A / potassium channel pathway. For instance, Nazario et al. ${ }^{7}$ demonstrated in cultured endothelial cells that BNP as well as ANP can stimulate CNP production through a guanylate cyclase receptor. CNP stimulates the natriuretic peptide receptor B (NPR-B) on adjacent vascular smooth muscle cells, thereby leading to increases in cellular CGMP, activation of potassium channels and vasodilatation. ${ }^{11,14}$

The CNP data from the present study provide additional support for our hypothesis that no interaction exists between NPR-A activation and stimulation of NO by BNP. Venous CNP levels increased significantly after local infusion of BNP alone as well as after BNP in combination with L-NMMA, there being no difference between both conditions. In as much as increased CNP "spillover" reflects NPR-A activation, it follows that the two pathways of action of BNP are independent from each other. Moreover, both in vitro and human studies have shown that CNP itself does not stimulate NO production. ${ }^{11,31}$ We do realise, however, that the net increase in CNP release can be influenced by (receptor) clearance, and that the only way to quantify CNP production correctly is using tracer-labelled CNP infusions. Therefore, some caution in the interpretation of our results remains warranted. With this proviso, Figure 6.4 gives a schematic account of how the various results from this study may be put together.

In disease states, such as hypertension and congestive heart failure, several mechanisms may be alltered and dysfunctional, including the sensitivity of BNP receptors, the status of potassium channels, and the production of $\mathrm{NO}$. Hence, one cannot directly extrapolate our findings to pathophysiological states. Furthermore, we were not able to study the mechanisms of BNP-induced vasodilatation in greater detail since NPR antagonists and/or CGMP inhibitors are not available for human use. 
Likewise, we could not differentiate between endothelium-dependent and -independent mechanisms. We do not know, therefore, to what extent potassium channels in the endothelial cells contribute to the actions of $B N P$, over and above those in smooth muscle cells.

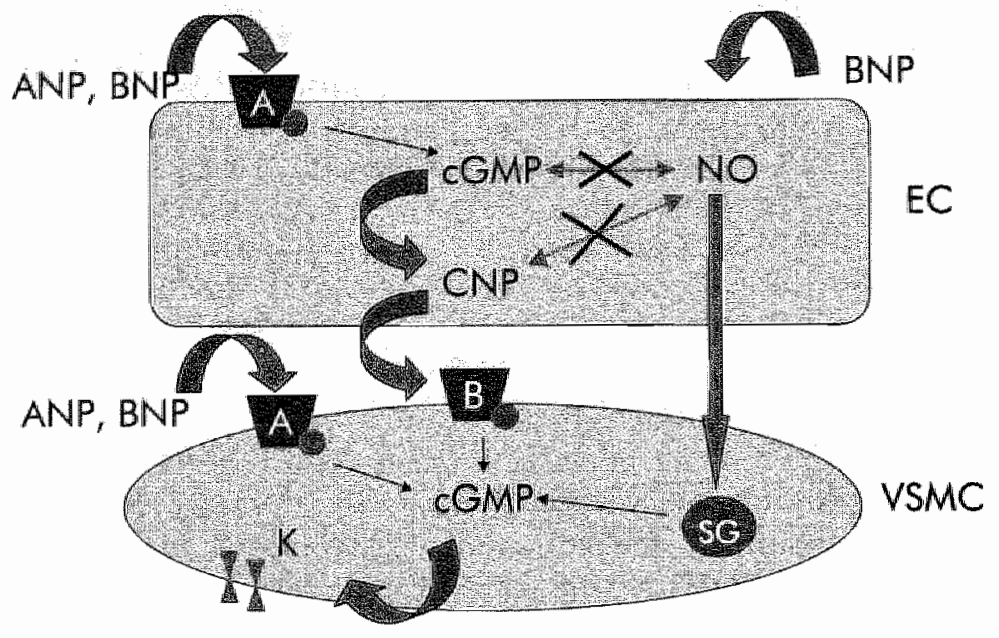

Figure 6.4 Simplified hypothetic overview of the vascular actions of BNP in humans. ANP, atrial natriuretic peptide; BNP, brain natriuretic peptide; CNP, C-type natriuretic peptide; NO, nitric axide; CGMP, cyclic GMP; $A$, guanylate cyclase bound natriuretic peptide receptor $A_{;} B_{*}$ natriuretic peptide receptor $B$; EC, endothelial cell; VSMC, vascular smoath muscle cell; $S G$, soluble guanylate cyclase; $\mathrm{K}^{*}, \mathrm{Ca}^{2+}$-activated potassium channel.

Another limitation of the present study is that we did not include a control group in which repeated BNP infusions were given without TEA or LNMMA. However, we have demonstrated previously that forearm vascular responses to BNP are remarkably reproducible upon repeated administration of the peptide and within the time frame of our studies no tachyphylaxis is to be expected. ${ }^{12}$ Another limitation is that we could not assess the effects of L-NMMA alone and L-NMMA in combination with TEA on separate days. Since the latter would have required a third intraarterial study, we preferred to combine these experiments on one day. In conclusion, the present data demonstrate that BNP induces vasodilatation in healthy men via at least two mechanisms: one involving hyperpolarisation via opening of $\mathrm{K}^{+} \mathrm{Ca2}+$-channels and one via stimulation of NO production. Furthermore, we have shown that BNP stimulates net CNP increase. 


\section{References}

1. Walther T, Stepan $H$ and Faber R. Dual natriuretic peptide response to volume load in the fetal circulation. Cardiowasc Res 2001; 49:817-819.

2. Lang $C C$, Choy $A M$, Turner $K$, Tobin $R$, Coutie $W$ and Struthers $A D$. The effect of intravenous saline loading on plasma levels of brain natriuretic peptide in man. I Hypertens 1993; 11:737.741.

3. Nishikimi $T$, Yoshihara $F$, Marimoto $A$, Ishikawa $K$, Ishimitsu $T_{n}$ Saito $Y$, et al. Relationship between left ventricular geometry and natriuretic peptide levels in essential hypertension. Hypertension 1996; 28: 22-30.

4. Mukoyama $M$, Nakao $K$, Hosoda $K$, Suga $S$, Saito $Y$, Ogawa $Y$, et al. Brain natriuretic peptide as a novel cardiac harmone in humans. Evidence for an exquisite dual natriuretic peptide system, atrial natriuretic peptide and brain natriuretic peptide. J Clin Invest 1991; 87: 1402-1412.

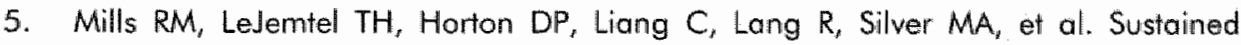
hemodynamic effects of an infusion of nesiritide (human b-type natriuretic peptide) in heart failure: a randomized, double-blind, placebo-controlled dinical trial. Natrecor Study Group. J Am Coll Cardiol 1999; 34: 155-162.

6. Colucci WS, Elkayam U, Horton DP, Abraham WT, Bourge RC, Jahnson AD, et al. Intravenous nesiritide, a natriuretic peptide, in the treatment of decompensated congestive heart failure. Nesiritide Study Group. N Engl IMed 2000; 3.43: $246-$ 253.

7. Nazario B, Hu RM, Pedram A, Prins B and Lewin ER. Atrial and brain natriuretic peptides stimulate the production and secretion of C-type natriuretic peptide from bovine aortic endothellial cells. J Clin Invest 1995; 95: 1151-1157.

8. Moritoki H, Yoshikawa T, Hisayama T and Takeuchi S. Possible mechanisms of ageassociated reduction of vascular relaxation caused by atrial natriuretic peptide. Eur I Pharmacol 1992; 210: 61-68.

9. Kubo M, Nakaya Y, Matsuaka S, Saito K and Kuroda Y. Atrial natriuretic factor and isosorbide dinitrate modulate the gating of ATP-sensitive $K+$ channels in cultured vascular smooth muscle cells. Circ Res 1994; 74:471-476.

10. Price JM and Hellermann A. Inhibition of CGMP mediated relaxation in small rat coronary arteries by black of $\mathrm{CA}++$ activated KH channels. Life Scil 1997; 61: $1185-1192$.

11. Honing ML, Smits $P$, Morrison PJ, Burnett JC, Jr, and Rabelink TJ. C-type natriuretic peptide-induced wasodilation is dependent on hyperpolarization in human forearm resistance vessels. Hypentension 2001; 37: $1179-1183$.

12. van der Zander K, Houben AJ, Kroon AA and de Leeuw PW. Effects of brain natriuretic peptide on forearm wasculature: comparison with atrial natriuretic peptide. Cardiovasc Res 1999; 44:595-600.

13. Nakamura $M$, Arakawa $N$, Yoshida $H$, Makita $S$, Ninuma $H$ and Hiramori $K$. Vasodilatory effects of B-type natriurefic peptide are impaired in patients with chronic heat failure. Am Heart J 1998; 135: 414-420.

14. Koller $\mathrm{KJ}$ and Goeddel DV. Molecular biology of the natriuretic peptides and their receptors. Circulation 1992;86:1081-1088. 
15. Bennett BD, Bennett GL, Vitangcol RV, Jewett JR, Burnier J, Henzel W, et al. Extracellular domain/gG fusion proteins for three human natriuretic peptide receptors. Hormone pharmacology and application to solid phase screening of synthetic peptide antisera. J Biol Chem 1991; 266:23060-23067.

16. Tsutamoto T, Kanamari T, Marigami N, Sugimoto Y, Yamaoka $O$ and Kinoshita M. Possibility of downregulation of atrial natriuretic peptide receptor coupled to guanylate cyclase in peripheral vascular beds of patients with chronic severe heart fallure [see comments]. Circulation 1993; 87: 70-75.

17. Zellner C, Protter AA, Ko E, Pothireddy MR, DeMarco T, Hutehison SJ, et al. Coronary wasodilator effects of BNP: mechanisms of action in coranary conductance and resistance arteries. Am J Physiol 11999; 276: H1049-1057.

18. Ishibashi $Y$, Shimada $T$, Sakane T, Takahashi N, Sugamori T, Ohhata $S$, el al. Contribution of endogenous nitric oxide to basal vasomotor tone of peripheral vessels and plasma B-type natriuretic peptide levels in patients with congestive heart. JAm Coll Cardial 2000; 36: 1605-1611.

19. World Medical Association Declaration of Helsirnki. Recommendations guiding physicians in biomedical research inwolving human subjects. Cardiovasc Res 1997 . 35: 2-3.

20. Pickkers $P$, Hughes AD, Russel FG, Thien $T$ and Smits $P$. Thiazide-induced vasodilation in humans is mediated by potassium channel activation. Hypertension 1998; 32: $1071-1076$

21. Houben AJ, Schaper NC, de Haan CH, Huwers FC, Slaaf DW, de Leeuw PW, et al. Local 24-h hyperglycemia does not affect endothelium-dependent or - independent vasoreactivity in humans. Am J Physiol 1996; 270: H2014-2020.

22. Honing ML, Smits P, Morrison PJ and Rabelink TJ. Bradykinin-induced vasodilation of human forearm resistance vessels is primarily mediated by endotheliumdependent hyperpolarization. Hypertension 2000; 35: 1314-1318.

23. Smits $P$, Williams SB, Lipson DE, Banitt $P$, Rongen GA and Creager MA. Endothelial release of nitric oxide contributes to the vasodilator effect of adenosine in humans. Circulation 1995; $92: 2135-2141$

24. Houben A., Slaaf DW, Huvers FC, de Leeuw PW, Nieuwenhuijzen Kruseman AC and Schaper NC. Diumal variations in total forearm and skin microcirculatory blood flow in man. Scand J Clin Lab Invest 1994; 54: 161-168.

25. Benjamin N, Calver A, Collier J, Robinson B, Vallance $P$ and Webb D. Measuring forearm blood flow and interpreting the responses to drugs and mediators. Hypertension 1995; 25: 918-923.

26. Nakamura $M$, Arakawa $N$, Yashida $H$, Makita $S$ and Hiramori K. Vasadilatory effects of $C$-type natriuretic peptide on forearm resistance vessels are distinct from those of atrial natriuretic peptide in chronic heart failure. Circulation 1994; 90 : 1210.1214.

27. Langton PD, Nelson MT, Huang $Y$ and Standen NB. Block of calcium-activated potassium channels in mammalian arterial myocytes by tetraethylammonium ions. Am J Physiol 1991; 260: H927-934.

28. Costa MD, Bosc LV, Majowicz MP, Vidal NA, Balaszczuk AM and Arranz CT. Atrial natriuretic peptide modifies arterial blood pressure through nitric oxide pathway in rats. Hypertension 2000; $35: 1119-1123$. 
29. McLay JS, Chatterjee PK, Jardine AG and Hawksworth GM. Atrial natriuretic factor modulates nitric axide praduction: an ANF-C receptor-mediated effect. I Hypertens $1995 ; 13: 625-630$.

30. Chen $\mathrm{HH}$ and Burnett JC, Jr. C-type natriuretic peptide: the endothelial component of the natriuretic peptide system. J Cardiovasc Pharmacol 1998; 32: 522-28.

31. Wennberg PW, Miller VM, Rabelink $T$ and Burnett JC, Jr. Further attenuation of endothelium-dependent relaxation imparted by natriuretic peptide receptor antagonism. Am J Physiol 1999; 277: H1618-1621. 


\title{
Chapter 7
}

\begin{abstract}
Review
"Brain natriuretic peptide in human physiology; compensating mechanism in vascular disease?"
\end{abstract}


chander 


\section{Introduction}

Brain natriuretic peptide (BNP), a member of the family of natriuretic peptides, receives increasing attention as a potential marker of cardiovascular disease. For instance, left ventricular hypertrophy (LVH) or left ventricular dysfunction are associated with increased BNP levels, and in patients with coronary insufficiency or heart failure, BNP has prognostic significance.' However, despite many investigations, the hemodynamic effects of BNP in man remain elusive. Due to differences in design, doses of BNP employed, and infusion time, data from the literature are difficult to compare.

The aim of this review is to summarize our current understanding of BNP, and discuss its regulation, its mechanisms of action and its role in pathophysiological states such as hypertension and heart failure.

\section{Regulation of plasma BNP}

Although BNP was first identified in the porcine brain ${ }^{2}$, this peptide is produced mainly in the cardiac ventricle and is secreted through the coronary sinus from the heart. ${ }^{3-6}$ The amino acid sequences of BNPs vary from species to species. ${ }^{7}$ In contrast to porcine BNP and rat BNP consisting of 26 and 45 amino acid residues respectively, in humans the major circulating form of BNP consists of 32 amino acids. Human BNP has a characteristic ring structure, formed by an intramolecular disulfide bridge, and amino- and carboxyl-terminall tails. ${ }^{7}$ The main stimulus for the acute release of BNP is wall stretch in response to chronic volume and pressure overload. 8,9 There are also non-hemodynamic components involved, whereas in the ventricles the level of BNP expression seems to be partly dependent upon neuroendocrine mechanisms. ${ }^{10,11}$ For instance, $\alpha_{1}$-adrenergic stimulation with phenylephrine (PE) results in increases in both BNP secretion and BNP gene expression, whereas stretch and endothelin-1 (ET-1) induce a marked increase in BNP gene expression alone. ${ }^{11,12}$

Normal plasma levels of BNP vary from 4 to $35 \mathrm{pg} / \mathrm{ml}$ (or 1.2 to 10 pmol/ly, ${ }^{33-22}$ These levels rise with age and are higher in females than in males. In man, intravascular saline loading has no effect on plasma BNP concentrations ${ }^{23}$, while an increase in dietary sodium stimulates BNP levels. ${ }^{24}$ Furthermore, plasma levels of BNP respond to posture-induced changes in central volume and fall, for instance, when the individual moves from the supine to the sitting position. ${ }^{25}$ The observation that plasma levels of BNP are elevated in disease states associated with volume overload, such as heart failure and some forms of hypertension, 
are in line with the hypothesis that BNP levels reflect one's extracellular volume. Hence, BNP may be used as a marker for left ventricular dysfunction or left ventricular hypertrophy (LVH), when these conditions are associated with disturbed valume control.

\section{Mechanisms of action}

Molecular cloning techniques have revealed three subtypes of natriuretic peptide receptors (NPR), named NPR-A, NPR-B, and NPR-C. ${ }^{26}$ in vitro studies suggest that BNP and ANP exert their vascular effects through the NPR-A. This membrane-bound guanylate cyclase receptor is located both on endothelial and vascular smooth muscle cells. ${ }^{27,28}$ Activation of this receptor generates CGMP, which as second messenger activates $\mathrm{Ca}^{2+}$ activated and ATP-sensitive potassium $\left(K^{+}\right)$-channels, thus promoting vasorelaxation. ${ }^{29,30}$ Furthermore, Nazario et al. demonstrated in cultured endothelial cells that BNP as well as ANP can stimulate c-type natriuretic peptide (CNP) production in endothelial cells through the guanylate cyclase receptor. ${ }^{27}$ CNP stimulates the NPR-B on adjacent vascular smooth muscle cells, thereby leading to increases in cellular cGMP, activation of potassium channels and vasodilatation. ${ }^{26}$ There is also some evidence from cellular and animal studies that natriuretic peptides are able to stimulate nitric oxide (NO) production ${ }^{31-33}$, which is probably mediated by the natriuretic peptide clearance receptor (NPR-C). The NPR-C decreases CAMP levels by adenylyl cyclase inhibition through an inhibitory guanine nucleotide-regulating protein. ${ }^{34}$ This suggests that besides being a clearance receptor, NPR-C is also biologically active. Natriuretic peptides are not only cleared by the NPR-C, but circulating ANP, BNP and CNP are also quickly metabolised and inactivated by the specific enzyme neutral endopeptidase (EC 24.11). However, BNP has a different plasma half-life than ANP. In human beings, the half-life of BNP has been reported to be approximately 20 minutes as opposed to 3 minutes for ANP. 3,35

In disease states it is possible that the NPR's are down-regulated for natriuretic peptides. Indeed, several studies have indicated that long-term exposure to exogenous ANP decreased receptor density and reduced responsiveness in terms of intracellular accumulation of CGMP in cultured vascular smooth muscle cells. ${ }^{36,37}$ This inhibition may also occur during exposure to BNP.

\section{Effects of BNP on the cardiovascular system}

Acute infusion of a pharmacological dose of BNP into normal subjects may lead to a rapid and sustained reduction in mean arterial blood 
pressure. $^{20}$ Mechanisms by which BNP produces this effect include diminished stroke volume, a reduction in systemic vascular resistance, and increased diuresis with ensuing intravascular volume depletion. Cardiac output and heart rate increase after pharmacological infusion of BNP, probably due to baroreceptor-mediated sympathetic activation in response to the fall in arterial blood pressure. However, like in chapter 2 , in most studies in which (patho)physiological doses of BNP were infused into healthy volunteers, no effects on mean arterial blood pressure were observed. ${ }^{16-19,21,22}$ In studies from Jensen et al. ${ }^{14,15}$ mean arterial pressure even slightly increased during low-dose BNP infusion. These investigations assessed the hemodynamic effects of placebo and different low doses of BNP infusion. However, the observed rise in MAP may be an aspecific phenomenon as this was also seen in the placebo group and no significant differences were found between placebo and BNP groups. ${ }^{1 / 4}$ Aside from the study by Holmes et al. ${ }^{19}$, no changes in heart rate have been found after infusion of BNP in doses not exceeding 4 $\mathrm{pmol} / \mathrm{kg} / \mathrm{min}$. ${ }^{14 \cdot 18,21,22}$ The incidental finding of an increase in heart rate can probably be explained by the influence of posture as Holmes et al. ${ }^{10}$ measured in sitting position in contrast to the other investigators. This explanation is supported by our own observation, described in chapter 2 , that BNP induced a significant fall in blood pressure and a rapid increase in heart rate only when our subjects switched from supine to sitting position. The observed decrease in plasma BNP in response to postureinduced changes in central volume could even be a compensating mechanism to prevent orthostatic hypertension. Furthermore, infusion of low doses of BNP into normal subjects does not reduce peripheral vascular resistance or cardiac output, while it decreases stroke volume. $^{16,18}$ These observations suggest that BNP does not primarily affect the arterial vascular bed, but rather reduces preload, possibly by lowering venous return. The latter may, of course, be secondary to reduced intravascular filling, although not necessarily so.

Similarly as in healthy subjects, BNP infusion in doses not exceeding 4 $\mathrm{pmo} / \mathrm{kg} / \mathrm{min}$ does not elicit any appreciable modifications of systemic hemodynamics and left ventricular performance either in patients with hypertension, who already have increased BNP plasma levels. ${ }^{38,39}$ When BNP was administered in higher doses, significant blood pressurelowering effects were observed, which were two- to threefold those of ANP. ${ }^{40}$ In patients with heart failure, BNP administered in lower doses (i.e. below $4 \mathrm{pmol} / \mathrm{kg} / \mathrm{min}$ ) infusion caused significant falls in blood pressure and leff ventricular filling pressure, without concomitant changes in cardiac output and heart rate. ${ }^{41,42}$ Just as in healthy subjects, Jensen et al. again found quite unexpectedly that the mean arterial blood pressure increased slightly in patients with CHF during BNP infusion. ${ }^{15}$ BNP in pharmacological doses $(30 \mathrm{pmol} / \mathrm{kg} / \mathrm{min})$ has a beneficial effect on left ventricular function similar to ANP by decreasing systemic vascular resistance and also by increasing stroke volume index. ${ }^{20,42,43}$ 
Taken together, in healthy subjects and hypertensive patients, low doses BNP has no appreciable effects on the cardiovascular system, but in pharmacological doses the peptide lowers blood pressure. On the other hand, both low and pharmacological dose of BNP have favourable effects on cardiovascular and renal hemodynamics in patients with heart failure. This can probably be explained by the fact that baseline BNP plasma levels are higher in patients with heart failure compared to healthy subjects and even more increased than in hypertensive patients. $3,6,25$

\section{Renal actions of BNP}

Although systemic infusion of BNP stimulates natriuresis and diuresis ${ }^{14,21}$, the hemodynamic effects of BNP on the renal vasculature are not clear. Most, but not all, studies in healthy humans have reported that BNP infusion increases glomerular filtration rate ${ }^{14,15,18,20}$, whereas renal plasma flow decreases ${ }^{14}$, increases ${ }^{18}$ or remains unchanged. ${ }^{15,17,21}$ One possible explanation for the variations in the renal effects of BNP may be that different BNP levels were reached during the experiments. Concurrent changes in GFR and RPF only occurred when the dose of BNP exceeded $2 \mathrm{pmol} / \mathrm{kg} / \mathrm{min} .{ }^{14,15,18,20}$ With lower doses of BNP, several authors ${ }^{17,19,21}$ observed a natriuretic and diuretic effect of BNP in the absence of changes in RPF and GFR. Although we have used a dose of BNP similar to that in the studies of Jensen et al. ${ }^{14}$ and La Villa et al. ${ }^{18}$ in chapter 2 and 4 , we could not demonstrate any change in RPF, while GFR increased. However, some caution is warranted in this respect. For instance, Jensen et al. ${ }^{14}$ did not compare placebo and BNP in the same subjects. This may have introduced at least some bias. The difference between our findings and those of La Villa et al. ${ }^{18}$ can probably be explained by the small number of (younger) subjects and the lower salt intake in their study as compared to ours. Jensen et al. ${ }^{14,15}$ have demonstrated by lithium clearance that proximal reabsorption of sodium may be reduced by BNP. These observations suggest that BNP has a direct effect on sodium handling within the kidney even in lower doses and without any changes in GFR or RPF.

In hypertensive patients BNP infusion also exerted a marked natriuresis and diuresis. Indeed, as in normal subjects concurrent changes in GFR only occurred when the dose of BNP exceeded $2 \mathrm{pmol} / \mathrm{kg} / \mathrm{min}$. $^{38^{39}}$ Infusion of BNP induced also natriuresis in patients with heart failure, but the natriuretic effect was impaired compared with healthy subjects and hypertensive patients ${ }^{15,20,41-43}$, most likely due to reduced responsiveness of the distal part of the nephron. ${ }^{15}$ 


\section{Local effects}

After studies that showed that human BNP could relax human arteries.4, we (in chapter 5) and others have demonstrated an in vivo dosedependent vasodilatation of the forearm vasculature of healthy subjects. ${ }^{45,46}$ However, in this respect BNP is less potent in comparison with ANP. ${ }^{45}$ The difference in effect may be related to a difference in affinity for the NPR-A ${ }^{26}$, but there is data in literature that does not support this concept. For instance, human BNP and ANP are equipotent in relaxing isolated preconstricted human arteries. ${ }^{44}$ Also, studies in cultured endothelial cells have shown that BNP and ANP have similar dissociation constants and maximal binding capacities for the NPR-A, and both peptides are equipotent in stimulation of endothelial CGMP production. ${ }^{47,48}$ BNP even induces a 20 -fold greater release of CNP by endothelial cells than ANP. ${ }^{27}$ Finally, the forearm blood flow responses to BNP were significantly lower in heart failure patients, and the difference in vasodilatation between BNP and ANP as observed in the healthy subjects was not present in patients with heart failure. ${ }^{46}$ To the best of our knowledge, no forearm study with BNP has been performed in patients with hypertension. In conclusion, these observations showed firstly that BNP and ANP act differently, and secondly, that more mechanisms must be involved than NPR-A alone, and thirdly, that the vasorelaxant capability of natriuretic peptides is impaired in patients with heart failure. Our findings from chapter 6 support the notion that BNP exerts its biological action, at least in part, not only through stimulation of CGMP and CNP production and opening of potassium channels, but also via NO production. ${ }^{49}$ These different pathways may account for a compensatory mechanism when endothelial function is impaired. In case of downregulation of the NPR-A production of NO will be more important. On the other hand, in case of decreased availability of $N O$, stimulation of the NPR-A augments CGMP generation. Recent studies have already emphasised the importance of BNP and NO, for example in heart failure ${ }^{50}$, but our results indicate that there is an interaction between the two. Further research is needed to elucidate how BNP stimulates NO production and if more pathways are involved in the biological effects of BNP.

\section{Current clinical interest and future perspectives}

Data from the literature of the last decade clearly delineate brain natriuretic peptide (BNP) as a cardiac hormone of clinical interest in diagnosis, prognosis and treatment of patients with heart failure as well as in patients with asymptomatic left ventricular systolic dysfunction. Basal plasma levells of BNP are used for classifying the degree of heart 
failure, which appears to be more objective than the NYHA (New York Heart Association) classification. A cut point of $100 \mathrm{pg} / \mathrm{mL}$ discriminates patients with congestive heart failure from those without congestive heart failure. Although both BNP and ANP increase in patients with heart failure, BNP plasma levels are more proportional to the functional severity of heart failure and frequently surpass ANP levels. Furthermore, it has been demonstrated that BNP can fall back to normal levels in wellcompensated patients despite persisting significant systolic dysfunction. ${ }^{51}$ This suggests that BNP assays may be helpful for monitoring adequacy of therapy, but that BNP assays will have limited ufility in the diagnosis of cardiac impairment once anti-failure therapy has been well established and symptoms have been abolished. Measurement of BNP may also be a screening tool for left ventricular dysfunction. However, in the large community-based sample of the Framingham heart study, the performance of BNP measurements for detection of elevated left ventricular mass and systolic dysfunction was suboptimal, suggesting limited usefulness of natriuretic peptides as mass screening tools. ${ }^{5}$

However, to consider natriuretic peptide levels only as a general and functionall indicator of cardiac structural disease, without recalling that atrial natriuretic peptide (ANP) and brain natriuretic peptide (BNP) are powerful hormones, may lead to underestimation of the physiological role these peptides play in healthy subjects as well as in patients with heart failure. In this view, a peptide currently manufactured by recombinant DNA technology and identical to endogenous BNP (nesiritide), has been evaluated in clinical trials as a therapeutic option. The drug produces a prompt fall in systemic vascular resistance and pulmonary capillary wedge pressure, associated with rapid clinical improvement in decompensated heart failure..$^{53,54}$ Nesiritide was even found to be more effective and better tolerated than the venous vasodilator nitroglycerin.

This thesis dealt mostly with healthy subjects to determine the specific hemodynamic effects of BNP on different target organs in an attempt to reveal -in vivo- the underlying mechanisms of action. On the basis of the results we can now hypothesise how BNP can play a key role in cardiovascular disease states. Our findings in chapter 5 that BNP is a mild dilator compared to equimolar doses of ANP, together with the lack of variation in renal blood flow after BNP infusion as described in chopter 2 and 3 , led us to hypothesize that the net effect of BNP is dependent on the balance between vasodilating and vasoconstrictor forces. An observation that supports this hypothesis is a study that showed that infusions of BNP in normal conscious dogs caused doserelated, reversible mesenteric vasoconstriction. ${ }^{55}$ Vasoconstrictor actions may counterbalance the other hemodynamic actions of BNP, thereby preferentially redistributing blood flow to prevent precipitous falls in arterial blood pressure. When arterial and venous filling pressures fall due to pharmacological doses of BNP, reflex sympathetic stimulation is to 
be expected. However, after low-dose BNP infusion a sympathoinhibitory effect of BNP has been demonstrated, whereas high dose BNP did not change systemic and cardiac sympathetic nervous activity. ${ }^{56}$ Furthermore, autonomic ganglion blockade with pentolinium did not prevent the BNPinduced mesenteric vasoconstriction. ${ }^{55}$ This suggests some direct vasoconstrictor actions of BNP on the vasculature, independent of the nervous system. However, changes of body position during administration of BNP does activate the baroreceptor reflex as we observed in chapter 2. When we combine our observations on the systemic and the peripheral vasculature, it would seem that the most probably site of action for BNP is the venous system where it may increase the 'unstressed' volume. This would explain, at least in part, the beneficial effects of this peptide in patients with heart failure. ${ }^{53,54}$

Another explanation for the vasoconstrictor potency of BNP could be that endothelin-1 (ET-1) acts as a possible mediator of the direct vascular actions of BNP. Indeed, it has been demonstrated before that a close relationship exists between BNP and ET-1 production at least within the kidney. $^{57}$ Apart from being a potent vasoconstrictor, ET-1 exhibits intrarenal natriuretic activity independently of changes in filtered load. ${ }^{58}$ The role of ET-1 in the kidney may even be dissociated from circulating ET-1. In fact, De Feo et al. demonstrated that systemic infusion of BNP is accompanied by increased urinary excretion of ET-1, cGMP and sodium, without changes in plasma ET-1.57 ET- 1 acts in an autocrine and paracrine manner on two subtypes of ET receptors, termed ET-A and ET$B$. These receptors are located on vascular smooth muscle cells and binding of ET-1 to these sites results in sustained vasoconstriction. However, ET-B receptors are also present on endothelial cells where their activation leads to production of $\mathrm{NO}$ and vasodilator prostanoids, and subsequent vasodilatation. In chapter 6 , we demonstrated that BNP acts partly via the production of NO. ${ }^{49}$ Thus, it may be that the close relationship between BNP and ET-1 production in the kidney means that ET-1 mediates (part of) the effects of BNP via the ET-B receptor. If this were the case, this would introduce an interesting novel interaction for therapeutical interventions. Indeed, currently a number of drugs are under investigation, which either inhibit the enzyme that degrades natriuretic peptides (neutral endopeptidase inhibitors) or block endothelin receptors. Both types of agents are evaluated for their potential in the treatment of cardiovascular disease. Concurrent administration of a neutral endopeptidase inhibitor and a selective ET-A receptor antagonist would greatly enhance BNP's effect on the kidney if ET-B receptors were to mediate these effects. As described in the study of chapter 4, however, ET-B receptor blockade did not influence the $B N P$-induced renal responses (enhanced GFR and natriuresis).

BNP could increase GFR in three possible ways, namely by preglomerular vasodilatation, by post-glomerular vasoconstriction, and/or by changing filtration surface area. The first possibility "pre-glomerular 
vasodilatafion, is not very likely to have occurred since we did not notice any changes in ERPF. Of course, we cannot exclude that BNP augments filtration surface area, but presently there are no good tools to investigate this in an unbiased way. For the time being, therefore, we consider post-glomerular vasoconstriction the most likely mechanism of the BNP-induced rise in GFR. It is still possible that ET-1 mediates the $B N P$-induced effects via the ET-A receptor, since experiments conducted on anaesthetised dogs with ET-A and ET-B specific antagonists, have shown that ET-B receptors predominantly account for diuresis and natriuresis, whilst the ET-A receptor is largly responsible for renal valsoconstriction. ${ }^{59}$

In conclusion, stimulation of BNP may be a compensating mechanism in vascular diseases, but endogenous BNP does not seem to be able to fully compensate for volume overload in hypertension and heart failure. The therapeutic benefits of BNP infusion are particular evident clear in patients with heart failure, although the hemodynamic effects of BNP appear to be dependent upon the used dose. Therefore, more research focussed on the specific mechanisms of action of BNP, and especially on the possible vasoconstrictor properties of BNP, is needed. 


\section{References}

1. Latini $R$, Masson $S$, De Angelis $N$ and Anand 1. Role of brain natriuratic peptide in the diagnosis and management of heat failure: Current concepts. I Card Fail 2002; 8: 288-299.

2. Sudoh $T$, Kangawa $K$, Minamino $N$ and Matsua $H$. A new natriuretic peptide in porcine brain. Nature 1988; 332: 78-81.

3. Mukoyama M, Nakao K, Hosoda K, et al. Brain natriuretic peptide as o novel cardiac hormone in humans. Evidence for an exquisite dual natriuretic peptide systen, atrial natriuretic peptide and brain natriuretic peptide. J Clin Invest 1991; 87: 1402-1412.

4. Ogawa $Y$, Nakao $K$, Mukoyama $M$, al. Natriuretic peptides as cardiac hormanes in normotensive and spontaneously hypertensive rats. The ventricle is a major site of synthesis and secretion of brain natriuretic peptide. Circ Res 1991; 69:491-500.

5. Hosoda $K$, Nakao $K$, Mukoyama $M_{r}$ et al. Expression of brain natriuretic peptide gene in human heart. Production in the ventricle. Hypertension 1991; 17: 1152. 1155.

6. Kohno $M$, Horia $T$, Yokokawa $K$ et al. Brain natriuretic peptide as a cardiac hormone in essential hypertension. Am J Med 1992; 92: 29-34.

7. Kambayashi $Y_{f}$ Nakao $K$, Mukoyama $M$, el al. Isolation and sequence determination of human brain natriuretic peptide in human atrium. FEBS Letters 1990; 259:341. 345.

8. Kinnunen P, Vuolteenaho $O$ and Ruskoaho $H$. Mechanisms of atrial and brain natriuretic peptide release from rat ventricular myocardium: effect of stretching. Endocrinology 1993; 132: 1961-1970.

9. Bianciotti LG and de Bold Al. Modultation of cardiac natriuretic peptide gene expression following endothelin type A receptor blockade in renovascular hypertension. Cardiovasc Res 2001; 49: 808-816.

10. Ogawa $T$, Linz W, Stevenson $M$, al al. Evidence for load-dependent and load. independentl determinants of cardiac natriuretic peptide production. Circulation $1996 ; 93: 2059-2067$.

11. Bruneau BG, Piazza LA and de Bold A.. BNP gene expression is specifically modulated by stretch and ET. 1 in a new model of isolated rat atria. Am J Physiol 1997; 273: H2678-2686.

12. Bruneau BG, Piazza LA and de Bold A.J. Alpha 1 -adrenergic stimulation of isolated rat atria results iru discoordinate increases in natriuretic peptide secretion and gene expression and enhances Egr-1 and c-Myc expression. Endocrinology 1996; 137 : 137.143.

13. Clerico A, Del Ry S, Maffei S, Prontera C, Emdin M and Giannessi D. The circulating levels of cardiac natriuretic hormones in healthy adults: effects of age and sex. Clin Chem Lab Med 2002; 40: 37 1 -377.

14. Jensen KT, Carstens J and Pedersen EB. Effect of BNP on renal hemodynamics, tubular function and vasoactive homones in humans. Am J Physiol 1998; 274 : F63.72.

15. Jensen KT, Eiskjaer $H$, Carstens $J$ and Pedersen EB. Renal effects of brain natriuretic peptide in patients with congestive heart failure. Clin Sci (Colch) 1999; 96:5-15. 
16. Lazzeri $C$, La Villa $G$, Bisi $G$, ef al Cardiovascular function during brain natriuretic peptide infusion in man. Cordiology $1995 ; 86: 396-401$.

17. La Villa $G$, Stefani $L$, Lazzeri $C$, ef al Acute effects of physiological increments of brain natriurefic peptide in humans. Hypertension 1995; 26:628-633.

18. La Villa $G$, fronzaroli $C$, Lazzeri $C_{f}$ ef al. Cardiovascular and renal effecis of low dase brain natriuretic peptide infusion in man. 1 Clin Endocrinol Metab 1994; 78 : $1166-1171$.

19. Holmes SJ, Espiner EA, Richards AM, Yandle TG and Frampton C. Renal, endocrine, and hemodynamic effects of human brain natriuretic peptide in nomal man. I Clin Endocrinol Metab 1993; 76:91-96.

20. Yoshimura $M$, Yasue $H$, Morita $E_{x}$ et al. Hemodynamic, renal, and hormonal responses to brain natriuretic peptide infusion in patients with congestive heart failure. Circulation 1991; 84: 1581-1588.

21. McGregor A, Richards M, Espiner E, Yandle T and lkram H. Brain natriuretic peptide administered to man: actions and metabolism. J Clin Endacrinol Metab 1990; 70: 1103-1107.

22. Cheung BM, Dickerson JE, Ashby MJ, Brown $M J$ and Brown J. Effects of physiological increments in human alpha-atrial natriuretic peptide and human brain natriuretic peptide in normal male subjects (published erratum appears in Clin Sci (Colch) 1994 Dec;87(6):following xxv]. Clin Sci (Colch) 1994; 86: 723-730.

23. Lang $C C$, Choy $A M$, Turner $K$, Tobin $R$, Coutie $W$ and Struthers $A D$. The effect of intravenous saline loading on plasma levels of brain natriuretic peptide in man. I Hypertens $1993 ; 11: 737.741$.

24. Lang CC, Coutie WJ, Khong TK, Choy AM and Struthers AD. Dietary sadium loading increases plasma brain natriuretic peptide levels in man. J Hypertens 1991; 9: 779-782.

25. La Villa $G$, Vena $S$, Conti $A$, et al. Plasma levels of brain natriuretic peptide in healthy subjects and patients with essential hypertension: response to pasture. Clin Sci (Lond) 1993; 85: $411-416$.

26. Koller KJ and Goeddel DV. Molecular biology of the natriuretic peptides and their receptors. Circulation 1992; 86: 1081-1088.

27. Nazario $B_{f}$ Hu RM, Pedram A, Prins B and Levin ER. Atrial and brain natriuretic peptides stimulate the production and secretion of $C$-type natriuretic peptide from bovine aortic endothelial cells. J Clin Invest 1995; 95: 1151-1157.

28. Moritoki H, Yoshikawa T, Hisayama T and Takeuchi S. Possible mechanisms af ageassociated reduction of vascular relaxation caused by atrial natriuretic peptide. Eur J Pharmacal 1992; 210:61-68.

29. Kubo M, Nakaya Y, Matsuoka S, Saito K and Kuroda Y. Atrial natriuretic factor and isosorbide dinitrate modulate the glating of ATP-sensitive $K+$ channels in cultured vascular smooth muscle cells. Circ Res 1994; 74: 471-476.

30. Price IM and Hellermann A. Inhibition of CGMP mediated relaxation in small rat coronary arteries by block of $\mathrm{CA}++$ activated $\mathrm{K}+$ channels. Life Sci 1997; 61: $1185-1192$.

31. Costa MD, Bosc LV, Majowicz MP, Vidal NA, Balaszczuk AM and Arranz CT. Atrial natriuretic peptide modifies arterial blood pressure through nitric oxide pathway in rats. Hypertension 2000; 35: $1119-1123$. 
32. McLay JS, Chatterjee PK, Jardine AG and Hawksworth GM. Atrial natriuretic factor modulates nitric oxide production: an ANF-C receptor-mediated effect. I Hypentens 1995: 13: 625.630.

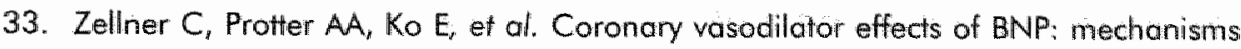
of action in coronary conductance and resistance anteries. Am J Physiol 1999; 276: H1049-1057.

34. Anand-Srivastava $M B$. Atrial natriuretic peptide-C receptor and membrane signalling in hypertension. J Hypertens, 1997; 15: 815-826.

35. Yandle TG, Richards AM, Nicholls MG, Cuneo $R$, Espiner EA and Livesey JH. Metabolic clearance rate and plasma half life of alpha-human atrial natriuretic peptide in man. Life Sci 1986; 38: 1827-1833.

36. Chabrier $P E$, Roubert $P$, Lonchampl MO, Plas $P$ and Braquet $P$. Receptor regulation of atrial natriuretic factor. Blood Vessels 1990; 27: 153-161.

37. Roubert $P$, Lonchampt $M O$, Chabrier PE, Plas $P$, Goullin J and Braquet $P$. Down regulation of atrial natriurefic factor receptors and correlation with CGMP stimulation in rat cultured vascular smooth muscle cells. Biochem Biophys Res Commun 1987; 1.48: 61-67.

38. Lazzeri $C$, Franchi $F$, Porciani $C$, et al. Systemic hemodynamics and renal function during brain natriuretic peptide infusion in patients with essential hypertension. Am I Hypertens 1995; 8: 799-807.

39. Richards AM, Crozier $1 G$, Holmes Sע, Espiner EA, Yandle TG and Frampton C. Brain natriuretic peptide: natriuretic and endacrine effects in essential hypertension. I Hypertens 1993; 11: 163-170.

40. Pidgeon GB, Richards AM, Nicholls MG, Espiner EA, Yandle TG and Frampton C. Differing metabolism and bioactivity of atrial and brain natriuretic peptides in essential hypertension. Hypertension 1996; 27: 906-913.

41. Lainchbury JG, Richards AM, Nicholls MG, ef al. The effects of pathophysiological increments in brain natriuretic peptide in left ventricular systollic dysfunction. Hypertension 1997; 30: 398-404.

42. Marcus $L S$, Hart $D$, Packer $M$, ef al Hemodynamic and renal excretory effects of human brain natriuretic peptide infusion in patients with congestive heart failure. A double- blind, placebo-controlled, randamized crossover trial. Circulation 1996; 94: $3184-3189$.

43. Yasue $H$ and Yoshimura $M$. Natriuretic peptides in the treatment of hear failure. I Card Fail 1996; 2: S277-285.

44. Protter AA, Wallace AM, Ferraris VA and Weisharar RE. Reloxant effect of human brain natriuretic peptide on human antery and vein tissue. Am J Hypertens 1996; 9 : $432 \times 436$.

45. van der Zander $K$, Houben AJ, Kroon AA and de Leeuw PW. Effects of brain natriuretic peptide on forearm vasculature: comparison with atrial natriuretic peptide. Cardiovasc Res 1999; 44: 595-600.

46. Nakamura M, Arakawa N, Yoshida H, Makita S, Niinuma $H$ and Hiramori $K$. Vasodilatory effects of B-type natriuretic peptide are impaired in patients with chronic heart failure. Am Heart $11998 ; 135: 414-420$. 
47. Gelfand RA, Frank HJ, Levin E and Pedram A. Brain and atrial natriureflic peptides bind to common receptors in brain capillary endothelial cells. Am J Physiol 1991; 261: E183-189.

48. Emori T, Hirata $\Psi$, Imai T, Eguchi S, Kanno K and Marumo F. Cellular mechanism of natriurenc peptides-induced inhibition of endothelin-1 biosynthesis in rat endothelial cells. Endocrinology 1993; 133: 2474-2480.

49. van der Zander K, Houben AJ, Kroon AA, De Mey JG, Smits PA and de Leeuw PW. Nitric oxide and potassium channels are involved in brain natriuretic peptide induced vasodilatation in man. 1 Hypertens $2002 ; 20: 493 m 499$.

50. Ishibashi $Y$, Shimada T, Sakane T, al. Contribution of endogenous nitric oxide to basal vasomotor tone of peripheral vessels and plasma B-type natriuretic peptide levels in patients with congestive heart failure [ln Process Citation]. I Am Coll Cordiol 2000; 36: 1605-1611.

51. MeGeoch G, Lainchbury J, Town GI, Toop L, Espiner E and Richards AM. Plasma brain natriuretic peptide after long-term treatment for heart failure in general practice. Eur J Heart Fail 2002; 4: 479-483.

52. Vasan RS, Benjamin EJ, Larson MG, ef al. Plasma natriurefic peptides for community screening for left ventricular hypertrophy and systolic dysfunction: the Framingham heart study. Jama 2002; 288: 1252-1259.

53. Colueci WS, Elkayam U, Harton DP, ef al. Intravenous nesiritide, a natriuretic peptide, in the treatment of decompensated congestive heart failure. Nesiritide Study Group. N Engl \Med 2000; 343: 246-253.

54. Mills RM, Lejemtel TH, Horton DP, et al, Sustained hemodynamic effects of an infusion of nesiritide (human b- type natriuretic peptide) in heart failure: a randomized, double-blind, placebo-controlled clinical trial. Natrecor Study Group. I Am Coll Cardiol 1999; 34: 155-1162.

55. Woads RL and Jones MJ. Atrial, B-type, and C-type natriuretic peptides cause mesenteric vasoconstriction in conscious dogs. Am J Physiol 1999; 276: R1443. 1452.

56. Brunner-La Rocca HP, Kaye DM, Woods RL, Hastings J and Esler MD. Effects of intravenous brain natriuretic peptide on regional sympathetic activity in patients with chronic heart failure as compared with healthy control subjects. I Am Coll Cardiol 2001; $37: 1221-1227$.

57. De Feo ML, La Villa $G$, Lazzeri $C$, ef al. Urinary endothelin-1 excretion is enhanced by low-dose infusion of brain natriuretic peptide in normal humans. Hypertension $1997 ; 29: 70-74$.

58. Nitta $K$, Naruse $M$, Sanaka $T$, ef al. Natriuretic and diuretic effects of endothelin in isolated perfused rat kidney. Endocrinol Jpn 1989; 36: 887.890.

59. Clavell AL, Stingo AJ, Margulies KB, Brandr RR and Burnett JC, Jr. Role of endothelin receptor subtypes in the in vivo regultation of renal function. Am I Physiol 1995; 268: F455-460. 


\section{Chapter 8}

Summary 


\section{Summary}

This thesis describes the local and systemic effects of BNP on different target organs (heart, kidney, forearm vasculature, and finger skin and conjunctival microcirculation) and which mechanisms play a role in these effects.

After a short general introduction in chapter 1, chapter 2 the hemodynamic and renal effects of low-dose BNP infusion in healthy subjects is described. BNP decreased stroke volume with a tendency to decrease cardiac output, possibly by lowering venous return. However, BNP did not affect the microvasculature, at least not in skin or conjuctiva. Infusion of BNP increased natriuresis, diuresis, GFR, filtration fraction, and filtered load of sodium, while ERPF did not change. We concluded that BNP has predominantly central and renal hemodynamic effects, while it does not influence peripheral micro-circulation.

The direct renal effects of BNP in hypertensive patients is investigated in the study described in chapter 3. Intrarenal BNP infusion did not induce significant changes in renal blood flow, despite increases in circulating levels of CGMP. In addition, we did not find any BNP-related changes in the CGMP gradient across the kidney, in the secretion of active renin and in creatinine extraction. These observations suggest a primarily extrarenal target of BNP. Another explanation could be that BNP, besides preglomerular vasodilatation, induces post-glomerular vasoconstriction, with the net effect that RPF remains constant.

Chapter 4 describes whether renal endothelin-1 could possibly mediate (part of) the effects of BNP via the ET-B receptor in healthy subjects. Apart from being a potent vasoconstrictor, endathelin-1 exhibits natriuretic activity independently from changes in filtered load. This effect of endothelin-1 is exerted via the endothelin-1 B receptor. However, while our study showed that selective ET-B receptor antagonism by itself decreased renal sodium excretion, it had no effect on the BNP-induced natriuresis and rise in glomerular filtration rate. Further studies are needed to elucidate a possible role of endotheline-1 (acting via the ET-A receptor) in mediating the renal effects of BNP.

The study in chapter 5 concerns the lacal vasoactive effects of BNP as compared to those of ANP in the forearm vasculature of healthy subjects. The results of this study showed that both BNP and ANP induce a dosedependent vasodilatation, which is repraducible in time. In addition, we found that the degree of vasodilatation induced by BNP is significantly 
less than those following equimolar doses of ANP. Since both BNP and ANP act through the same receptor, these findings suggest that more pathways are involved in the bialogical action of BNP.

The mechanisms of action of BNP in the human forearm were further investigated in chapter 6 . This study demonstrated that BNP, besides activation of natriuretic peptide receptor $A$ and thereby opening of potassium-channels, also stimulated nitric oxide (NO) production to induce vasodilatation in the human forearm. Furthermore, we showed that BNP stimulates CGMP and c-type natriuretic peptide production.

In chapter 7 the results of the above-mentioned studies were discussed in the context of current literature. Finally, the clinical relevance of our results for the treatment and/or prevention of hypertension and/or heart failure is described. 


\section{Chapter 9}

Samenvatting 


\section{Samenvatting}

Dit proefschrift beschrifft de lokale en systemische effecten van BNP op verschillende doelorganen (hart, nieren, onderarmbloedvaten, en de kleine bloedvaten van oog en nagelplooil en welke werkingsmechanismen daaraan ten grondslag liggen.

Na een korte introductie in hoofdstuk 1, worden in hoofdstuk 2 de hemodynamische en renale effecten van infusie van een lage dosis BNP ten opzichte van placebo bii gezonde proefpersonen beschreven. BNP blijkt de hoeveelheid bloed die het hart uitpompt, vermoedelijk als gevolg van een verlaagd aanbod van blaed vanuit de circulatie, te verlagen. BNP heeft echter geen effect op de kleine bloedvaten van oog en nagelplooi. De nieren gaan, door de infusie van BNP, meer water en zout vitscheiden zonder dat ze meer bloed van het hart aangeleverd krijgen. De nierdoorbloeding verandert niet door BNP, maar de hoeveelheid bloed die wordt gefilterd door de nieren stijgt. We concluderen dat BNP alleen effect lijkt te hebben op de centrale en renale hemodynamiek, zonder de perifere hemodynamiek te beïnvloeden.

De effecten van BNP op de nier worden op lokaal niveau verder onderzocht bii mensen met hoge bloeddruk, zocls beschreven in hoofdstuk 3. We kunnen geen direct effect aantonen van BNP op de nierdoorbloeding of filtratie, ondanks een stijging van de second messenger van BNP (cGMP). Dit wil zeggen dat de nieren het effect van BNP op de rest van de circulatie nodig hebben om zout- en wateruitscheiding te kunnen bewerkstelligen. Een andere verklaring zou kunnen zijn dat BNP naast preglomerulaire vaatwerwiijding ook voor post-glomerulaire vaatvernauwing zorgt. De filtratiedruk in de nier zou op deze wijze hoog gehouden kunnen worden om meer bloed te filteren, zonder dat er een toename in doorbloeding optreedt.

In hoofdstuk 4 wordt de rol van intrarenaal endotheline- 1 beschreven als mogelijke mediator van de effecten van BNP op de nier bii gezonden. Endotheline-1 zorgt namelijk naast vaatvernauwing ook voor zoutuitscheiding door de nier. Dit effect komt tot stand via de zogenaamde endotheline-1 B receptor. Uit ons onderzoek blijkt echter dat selectief endotheline- 1 B receptor antagonisme op zich wel leidt tot een verminderde zoutuitscheiding, maar dat het geen effect heeft op de door BNP teweeggebrachte toename in zoutuitscheiding en glomerulaire filtratie. Een eventuele rol van endotheline-1 via de endotheline A receptor zal in de toekomst nog nader onderzocht moeten worden. 
Het onderzoek vif hoofdstuk 5 betreft het lokale effect van BNP in de anderarm van gezonde proefpersonen. In deze studie wordt het effect van BNP vergeleken met het effect van ANP. Ten eerste tonen we aan dat de effecten van beide natriuretische peptiden reproduceerbaar zijn in de tijd. Vervolgens zien we dat BNP voor een dosis-afhankelijke vaatverwijding zorgt, maar een geringer vaatverwijdend vermogen heeft dan ANP. Omdat tot dan alleen bekend was dat BNP en ANP via dezelfde receptor hun biologisch effect vitoefenen, ontstaat het vermoeden dat meer dan één mechanisme betrokken is bij de werking van BNP.

De onderliggende werkingsmechanismen van BNP in de onderarm worden nader onderzocht in hoofdstuk 6. Hierulit blijkt dat naast activatie van de natriuretische peptide receptor $A$ en daarmee opening van kalium-kanalen, aok stimulatie van stikstofoxide (NO) leidt tot vaatverwijding in de onderarm. Hierbij worden tevens CGMP en c-type natriuretisch peptide geproduceerd.

In hoofdstuk 7 worden de resultaten van bovengeschreven onderzoeken besproken in de context van de huidige literatuur. Tenslotte wordt tevens de klinische relevantie aangegeven van de onderzoeksresultaten voor de behandeling en/of preventie van hoge bloeddruk en/of hartfalen. 
List of publications 


\section{List of publications}

\section{Articles}

K van der Zander, A.lHM Houben, AA Kroon, and PW de Leeuw. Effects of brain natriuretic peptide on forearm vasculature: comparison with atrial natriuretic peptide. Cardiovasc Res 1999; 44: 595-600.

TKA Wierema, AJHM Houben, AA Kroon, D Koster, K van der Zander, JMA van Engelshoven and PW de Leeuw. Nitric oxide dependence of renal blood flow in patients with renal artery stenosis. J Am Soc Nephrol $2001 ; 12: 1836-1843$.

K van der Zander, AJHM Houben, AA Kroon, JGR DeMey, PABM Smits and PW de Leeuw. Nitric oxide and potassium channels are involved in brain natriuretic peptide induced vasodilatation in man. J Hypertens 2002; 20: 493-499.

K. van der Zander, AJHM Houben, AA Kroon, TKA Wierema, MJMJ FussLejeune, D Koster, and PW de Leeuw. Does Brain natriuretic peptide have a direct renal effect in human hypertensives? Hypertension 2003; 41: 119-123.

K van der Zander, AJHM Houben, L Hofstra, AA Kroon, and PW de Leeuw. Hemodynamic and renal effects of low-dose brain natriurefic peptide infusion in man: a randomised placebo-controlled cross-over study. Am J Physiol; provisionally accepted.

$K$ van der Zander, DJ Webb, NR Johnston, JGR De Mey, AJHM Houben, and PW de Leeuw. Selective endothelin-1 B receptor blockade inhibits basal, but not BNP-induced natriuresis. Hypertension; submitted.

$K$ van der Zander and PW de Leeuw. Brain natriuretic peptide in human physiology; compensating mechanism in vascular disease? J Vasc Res; submitted. 


\section{Abstracts}

$K$ van der Zander, AJHM Houben, AA Kroon, EH Lambrichs, MJMJ FussLejeune, and PW de Leeuw. Effects of brain natriuretic peptide on forearm vasculature: comparison with atrial natriuretic peptide. I Hypertens 1999; 17(suppl.3): $\$ 97$.

$K$ van der Zander, AJHM Houben, JGR De Mey, P Smits, PW de Leeuw. Potassium $\left(K^{+}\right)$-channel activation is involved in brain natriuretic peptide (BNP)-induced vasodilation in man. Eur J Clin Invest 2000; 30(suppl. 1): 30.

K van der Zander, A.JHM Houben, JGR De Mey, P Smits, PW de Leeuw. Potassium channel activation is involved in brain natriuretic peptide (BNP)-induced vasodilation in man. J Hypertens 2000; 18(suppl.2): S13.

TKA Wierema, AJHM Houben, K van der Zander, MJMJ Fuss-Lejeune, AA Kroon, PW de Leeuw. Greater dependency upon renal nitric oxide synthase (NOS) in patients with renal artery stenosis. J Hypertens 2000; 18(suppl.2): 5105.

K van der Zander, A Houben, J De Mey, P Smits, P de Leeuw. Potassium channel activation is invalved in brain natriuretic peptide (BNP)-induced vasodilation in man. J Hypertens 2000; 18(suppl.4): S63.

T Wierema, A Houben, A Kroon, D Koster, K van der Zander, J Van Engelshoven, $\mathrm{P}$ de Leeuw. Nitric oxide dependency of renal blood flow in hypertension with or without renal artery stenosis. J Hypertens 2000; 18(suppl.4): S106.

K van der Zander, AJHM Houben, L Hofstra, AA Kroon, PW de Leeuw. Central and peripheral hemodynamic effects of brain natriuretic peptide infusion in man. J Hypertens 2002; 20(suppl.4): \$220. 
Dankwoord 


\section{Dankwoord}

Heł werken aan dit proefschrift was een leerzaam proces. Van een stagiair gezondheidswetenschappen gegroeid naar een zelfstandige onderzoeker. Een van de dingen die ik heb geleerd is, dat je je eigen mogelijkheden moet creëren om je doelstellingen te kunnen bereiken. Actief participeren in je omgeving met creativiteit, flexibiliteit en doorzettingsvermogen. Niet alleen wetenschappelijk, maar dus zeei" zeker ook persoonlijk heb ik mij de afgelopen periode kunnen ontwikkelen, mede dankzii de bijdrage van de hier genoemde personen.

Allereerst gaat een speciaal woord van dank naar alle 75 proefpersonen die hebben deelgenomen aan de 160 "echte" meetdagen van de 6 studies waaraan ik de afgelopen jaren heb gewerkt. Zonder de bereidwilligheid van hen (tijdens de honderden screeningsvisites zochten we altijd net naar dat ene speciale kenmerk...), was de totstandkoming van dit boekje niet mogelijk geweest.

Mijn promotor Prof. dr PW de Leeuw, beste Peter, in het begin van miin promotieperiode was je er steeds voor de finishing touch, maar hoe dieper ik in de materie kwam (het hele mechanisme bleek ingewikkelder dan voorzien!), des te enthousiaster werden de wekelijkse brainstormen over het onderwerp. Jouw enorme wetenschappelijke en klinische kennis over de nieren, hart en bloedvaten waren van onschatbare waarde voor mijn inspiratie voor dit onderzoek. Mede dankzii jouw grote inzet en intensieve begeleiding, is het toch gelukt om diverse vasculaire effecten en onderliggende mechanismen van BNP in dit proefschrift te beschrijven.

Mijn co-promotor dr AJHM Houben, beste Boy, als student kwam ik bij je binnen met de vraag of ik bij jullie stage kon komen lopen, omdat ik graag klinische en ook ex-vivo technieken wilde leren, naast de in vitro technieken die ik tijdens mijn studie al had geleerd. Aangezien dat ik de meeste gebruikte technieken uit dit proefschrift van jou heb kunnen leren, heb jii je ruimschoots aan deze belofte gehouden. Dit was je eerste rol als co-promotor en ondanks dat onze prioriteiten niet altijd op een lijn lagen, wil ik je enorm bedanken, dat we dit proefschrift samen binnen de gestelde tijd tot een goed einde wisten te brengen.

Zonder circulatie-lab geen onderzoek. Mijn dank gaat uit naar Claudia, Monique en Dorien. Zij zijn de spil van elk onderzoek voor wat betreft benodigdheden, organisatie, planning, opslag en aanlevering van monsters, kortom 3 extra paar handen! Maar zonder circulatie-lab aok 
geen gezelligheid... menig uitstapje, verjaardag, kerstdiner, beschuit met muisjes en afscheid zijn van hieruit georganiseerd. Dit heb ik de afgelopen jaren erg gewaardeerd en zorgde voor een groot stuk plezier op de werkvloer.

Direct bil het circulatie-lab betrokken zijn natuurlijk mijn medepromovendi en andere circulatie-lab medewerkers. Esther, Wilko, Marrigie, Marieke, Thomas, Sergio, Willem, Jörgen, Léon, Suuske en Stella, allemaal lopen/liepen we met tijiden op het lab rond om onze onderzoeken vit te voeren. Mede ook door congressen leerden we elkaar ook van een heel andere kant kennen. Met als gevolg een hechte groep, altijd bereid waar nodig bij te springen! Bedankt en veel succes voor jullie toekomst.

Verder wil ik Prof. JGR De Mey bedanken voor zijn bijdrage. Beste Jo, vanaf de zijliin, maar toch jouw voortdurende belangstelling en enthousiasme voor mijn onderzoek, ook nadat de ex-vivo experimenten geen bevredigende resultaten lieten zien, hebben mii enorm gemotiveerd. Jouw kennis en kritische blik waren van groot belang bij het opzetten van studies en het beoordelen van resultaten.

In deze alinea mag ook zeker Marijke Sanders niet vergeten worden. De vele hulp die zij geboden heeft bij mijn ex-vivo experimenten heb ik zeer op prijs gesteld.

Dr AA Kroon en dr NC Schaper, beste Bram en Nicolaas, jullie ben ik dankbaar voor alle tips en klinische achtergrond tijdens de experimenten, maar vooral voor het vakkundig aanprikken van de diverse aders en slagaders.

Dr Leo Hofstra en Bas Kietselaar wil ik bedanken voor alle ondersteuning bii, an andiyses ven dre hantrechrós.

De afdeling diëtetiek en in het bijzonder Esther Moonen ben ik erkentelijk voor het verzorgen van het "mild zout" dieet voor alle proefpersonen.

Paul Schiffers en Jet Bost van het neurohumorale lab en Lou Habets en Armand Gubbels van KCL dank ik voor de accurate monsterbepalingen.

Tevens bedank ik alle andere personen binnen de universiteit en het ziekenhuis (secretariaat, CARIM, apotheek, etc.) die een biidrage hebben geleverd aan mijn promotie.

De leden van de beoordelingscommissie, Prof. dr HAJ Struijker-Boudier, Prof. dr MP van Dieijen-Visser en Prof. dr HJ Crijns wil ik bedanken voor het kritisch beoordelen van mijn manuscript. I also would like to thank Prof. dr EB Pedersen and Prof. dr DJ Webb for their interest in my studies during international meetings and for their willingness to review my manuscript. I hope that you both will be present at my thesis defense. 
Een woord van dank gaat ook uit naar Tiny Wouters. Zij heeft op ofstand heel mijn proefschrift drukklaar gemaakt. Op het moment dat je in Vlaardingen een nieuwe baan begint, is zo iemand goud waard! Jeroen de Bruin komt alle lof toe voor wat betreft de mooi ontworpen kaft.

Esther en Monique, niet alleen fijne collega's, maar ook een vriendschap. Bedankt dat jullie mijn paranimf wilden zijn.

Van mijn overige vrienden wil ik er twee in hel bijzonder noemen. Lieve Maud en Daniela, al 22 jaar zijn jullie goede vriendinnen en ik wil jullie bedanken voor alle steun. Het is voor jullie moeilijk voor te stellen wat ik nu al die jaren heb gedaan, maar ik ben waanzinnig trots op jullie persoonlijke bijdragen aan dit boekje!

Als uitzondering op de regel, heb ik ouders die beter begriipen wat 'AlOzijn' inhoudt. Voor jullie; papa en mama bedankt voor alle geduld en adviezen, dankzii jullie weet ik dat ik er nooit alleen voor sta! Falke, Joost en Floor, ik hoop dat we nog jaren geregeld allemaal thuis in Sittard zijn... 
Curriculum Vitae 


\section{Curriculum Vitae}

Kim van der Zander werd op 30 september 1976 geboren te Sittard. Aan het College te Sittard werd in 1994 het VWO diploma behaald. Datzelfde jaar startte zij met de studie Gezondheidswetenschappen aan de Universiteif Maastricht, met als afstudeerrichting Biologische Gezondheidkunde. Na een stage bij de vakgroep Interne Geneeskunde van het academisch ziekenhuis Maastricht onder leiding van dr. AJHM Houben (Interne Geneeskunde, $a z M$ ) en dr. J Heemskerk (Humane Biologie, UM) werd het doctoraal diploma behaald in november 1998. Op 1 december 1998 begon zij als onderzoekassistent onder leiding van Prof. dr. PW de Leeuw bij diezelfde vakgroep binnen het Cardiovasculair Research Instituut Maastricht (CARIM). Zii was werkzaam aan een klinische trial van de farmaceut Servier en maakte een begin met haar promotie-onderzoek. In september 2000 werd deze aanstelling met 2 jaar verlengd als Assistent in Opleiding (AIO-2) om het in dit proefschrift beschreven onderzoek of te ronden. Vanaf 1 december 2002 is zij werkzaam als Research Scientist bij Unilever Research and Development in Vlaardingen. 